TI 2015-094/V

Tinbergen Institute Discussion Paper

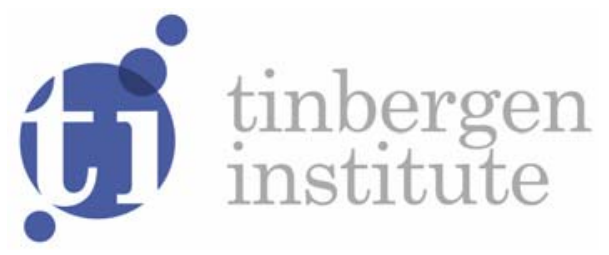

\title{
Early Life Circumstances and Life Cycle Labor Market Outcomes
}

\author{
Manuel Flores ${ }^{7}$ \\ Pilar García-Gómez² \\ Adriaan Kalwij3
}

${ }^{\prime}$ Directorate for Employment, Labor and Social Affairs, Organization for Economic Cooperation and Development OECD, France;

2 Erasmus School of Economics, Erasmus University Rotterdam, and Tinbergen Institute, the Netherlands;

3 Utrecht University, the Netherlands. 
Tinbergen Institute is the graduate school and research institute in economics of Erasmus University Rotterdam, the University of Amsterdam and VU University Amsterdam.

More TI discussion papers can be downloaded at http://www.tinbergen.nl

Tinbergen Institute has two locations:

Tinbergen Institute Amsterdam

Gustav Mahlerplein 117

1082 MS Amsterdam

The Netherlands

Tel.: +31(0)205251600

Tinbergen Institute Rotterdam

Burg. Oudlaan 50

3062 PA Rotterdam

The Netherlands

Tel.: +31(0)10 4088900

Fax: $+31(0) 104089031$

Duisenberg school of finance is a collaboration of the Dutch financial sector and universities, with the ambition to support innovative research and offer top quality academic education in core areas of finance.

DSF research papers can be downloaded at: http://www.dsf.nl/

Duisenberg school of finance

Gustav Mahlerplein 117

1082 MS Amsterdam

The Netherlands

Tel.: +31(0)20 5258579 


\title{
Early life circumstances and life cycle labor market outcomes
}

\author{
Manuel Flores $^{\mathrm{a}, *}$, Pilar García-Gómez ${ }^{\mathrm{b}}$, Adriaan Kalwij

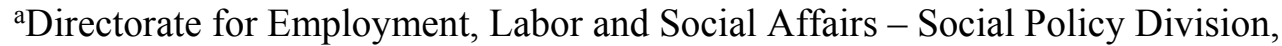 \\ Organization for Economic Cooperation and Development \\ ${ }^{b}$ Erasmus School of Economics, Erasmus University Rotterdam and Tinbergen Institute \\ ${ }^{c}$ Utrecht University School of Economics and Network for Studies on Pensions, Aging \\ and Retirement (Netspar) \\ *Corresponding author. Address: 2 Rue André-Pascal, 75775 Paris CEDEX 16, France. \\ Phone: +(33-1) 452491 90. Email: manuel.flores@oecd.org
}

July 4, 2015

\begin{abstract}
We investigate how early life circumstances - childhood health and socioeconomic status (SES) - are associated with labor market outcomes over an individual's entire life cycle. A life cycle approach provides insights not only into which labor market outcomes are associated with adverse childhood events but also into whether these associations show up early or only later in working life, and whether they vanish or persist over the life cycle. The analysis is conducted using the Survey of Health, Aging and Retirement in Europe, which contains retrospective information on early life circumstances and full work histories for over 20,000 individuals in thirteen European countries. We find that the associations between early life circumstances and (accumulated) labor market outcomes vary over an individual's life cycle. For men and women, the effect of childhood SES on lifetime earnings accumulates over the life cycle through the associations with both working years and annual earnings. Moreover, for men this association with lifetime earnings reverses sign from negative to positive over their working life. We also find a smaller, positive long-term association between childhood health and lifetime earnings operating mainly through annual earnings and only to a lesser extent through working years, and which is not present at the beginning of the working life for women. Most of these life cycle profiles differ between European country-groups. Finally, for women we find a so-called buffering effect, i.e. that a higher parental SES reduces the negative impact of poor health during childhood on accumulated earnings over the life cycle.
\end{abstract}

JEL Classification: D10, I14, J14, J24, J31, O15

Keywords: Early life circumstances, lifetime earnings, life cycle, SHARE 


\section{Introduction}

There is a growing literature that demonstrates that early life circumstances have longlasting effects on later life health and socioeconomic status (SES)-related outcomes such as earnings and work effort (Almond and Currie 2011a, Black and Devereux 2011). However, to the best of our knowledge, there is no empirical study to date that has attempted to quantify how such early life circumstances relate to individual earnings and other labor market outcomes over the entire life cycle. This is particularly worthy of investigation if some consequences of adverse events early in life may not become apparent until later in adult life (Barker 1995, Almond and Currie 2011b) or if their impacts accumulate over the life cycle (Kuh and Wadsworth 1993). Therefore, studies that focus on a single age later in life-as is common in this literature-are likely to give incomplete or even biased estimates of the total impacts that early life circumstances have on individuals' labor market outcomes over the entire life cycle. ${ }^{1}$

Our main contribution to the existing empirical literature on the relationship between early life circumstances and later life earnings is, therefore, that we use a life cycle approach to test whether some of these associations show up early in the life cycle or instead appear at later ages, and whether they vanish or persist over the life cycle. For this, we use retrospective data on respondents' early life circumstances and full work histories from thirteen European countries to measure the associations of early life circumstances (childhood health and parental SES) with lifetime earnings at a variety of ages over the entire life cycle. This provides a more comprehensive picture on how these associations evolve over the life cycle than is currently available in the literature. For instance, for both men and women we find evidence of a cumulative impact of childhood

\footnotetext{
${ }^{1}$ In the literature on intergenerational earnings mobility this is referred to as a life cycle bias that stems from an increasing association over the child's life cycle between (annual) earnings of the child and lifetime earnings of the parent (e.g. Haider and Solon 2006).
} 
SES on lifetime earnings over the life cycle. For men, however, this association is negative at early stages of their working life and reverses sign from negative to positive in their mid thirties. To a lesser extent, childhood health also shows a positive, long-term association with lifetime earnings over the life cycle, and while for men most of this association is already present at the beginning of their working life (at age 25), for women it kicks in just from that age onward. In particular our finding of an increasing association between childhood SES and accumulated earnings over the life cycle emphasizes the importance of not focusing on a single age later in life if one is interested in the overall effect that early life circumstances have on labor market outcomes, but focusing on individuals' entire life cycles.

A further contribution of our paper is that we shed light on the implicit labor market behavior behind this association, i.e. on whether the association between early life circumstances and accumulated lifetime earnings operates through the number of years worked or through average annual earnings. Our main results show that for both men and women in Europe, the strong evidence of a cumulative impact of childhood SES on lifetime earnings over the life cycle operates through both working years and annual earnings. Most importantly, we show that the associations between early life circumstances and (accumulated) labor market outcomes are not constant over an individual's life cycle. In particular for working years, we find a strong negative association with childhood SES at the beginning of the working life, which decreases with age as individuals with a higher childhood SES also enter the labor market and those with a low childhood SES accumulate more employment gaps. This finding could explain Smith's (2009) apparently surprising result of an insignificant association of parental income and educational levels with (annual) weeks worked in adulthood (at ages 25-47), and also Case et al.'s (2005) result for British men of a positive association between 
family income at age 16 and the employment probability at age 42 , one that is, however, insignificant at age 33. We also find that the smaller, quite persistent, positive long-term association between childhood health and lifetime earnings operates mainly through annual earnings and only to a lesser extent through working years.

Previous studies (Case et al. 2002; Currie and Stabile 2003) also argue that income buffers children from the negative effects of adverse childhood health; this is called the buffering hypothesis. Therefore, an additional contribution of the paper is that we test whether a higher parental SES reduces the negative impact of poor health during childhood on accumulated earnings over the life cycle, and find some evidence in favor of this buffering hypothesis for women but not for men.

Last, we explore whether there are differences in the life cycle profiles between European country-groups, which is what one could expect given the cross-country differences in levels of development, labor market conditions and social protection policies, amongst others, over the period of analysis. Our results show that, in particular for women, most of these associations (for instance, those with accumulated earnings) are larger in the Mediterranean and Continental countries than in Nordic and Transitional countries. For all groups, however, we find a relatively strong, cumulative impact of childhood SES on earnings over the life cycle which operates through both annual earnings and working years.

The remainder of the paper is organized into six sections. The first summarizes previous studies that examine the effects of early life circumstances (childhood health and parental SES) on labor market outcomes later in life. Section 3 describes the data and the main variables for analysis. In Section 4, we use a life cycle approach to investigate the associations of early life circumstances with lifetime earnings. In addition, we explore the associations of early life circumstances with different labor 
market outcomes that may drive the previous association and also test for the buffering hypothesis in lifetime earnings. In Section 5, we examine whether some of these associations over the life cycle differ between European country-groups. Section 6 analyzes the robustness of our main results. Section 7 summarizes the main findings and concludes.

\section{Background}

Several previous studies have shown the effects of childhood SES on earnings at a specific age in adulthood. Some of the first studies in addressing this issue focus on parental education to investigate the so-called family background bias in returns to education in earnings equations (Behrman and Wolfe 1984, Heckman and Hotz 1986, Lam and Schöeni 1993), usually identifying a larger association with mother's education than with father's education (see also Behrman and Rosenzweig 2004). Parental income is also widely known to be positively associated with individual's later life earnings in the literature on intergenerational mobility in earnings. Moreover, these intergenerational elasticities in earnings vary across gender, time, country and age of both the parents and offspring (see Black and Deveraux (2011) for a survey). More recently, two studies explore the role of income shocks induced by changes in the labor market status of a parent (due to firm closures), providing evidence for Canada (Oreopoulos et al. 2008) but no evidence for Norway (Bratberg et al. 2008) of a causal effect of parental income on children's earnings early in adulthood (at ages 25-33 and 25-30 respectively). Brunello et al. (2012) use a similar dataset to our study and tackle the aforementioned life cycle bias by examining the associations of early life circumstances with individual's total lifetime earnings. They find a long-term association between access to books in the parental home-a measure for parents' 
cultural background or education - and lifetime earnings for men in Europe, but provide no evidence on how these associations with accumulated earnings evolve over a life cycle.

Also the relationship between childhood health and later life earnings has received a great deal of attention in the empirical literature. For instance, Black et al. (2007) use administrative data for a sample of Norwegian twins and find a positive association between birth weight - a measure for health in utero-and earnings in early adulthood (at ages 25-35) that is similar with and without controlling for twin fixed effects. Similarly, Behrman and Rosenzweig (2004) use a U.S. sample of female monozygotic (MZ) twins but find that the (positive) association between birth weight and hourly wages in mid adulthood (at ages 39-58) is significant when controlling for (MZ) twin fixed effects only. Alternatively, Almond (2006) uses the 1918 Influenza Pandemic as a measure of a health shock around birth and shows that it reduced annual wage income of U.S. men in mid adulthood (at about ages 40, 50 or 60). However, Nelson (2010), who uses also the 1918 Influenza Pandemic, does not find a significant effect on hourly wages of relatively old males (above age 65) in Brazil, and Chen and Zhou (2007), who use the 1959-1961 famine in China, find only limited evidence of a negative effect on the earnings of the survivors in rural areas in early adulthood (at ages 24-37). In a paper that is closely tied to our work, Goodman et al. (2011) use prospectively collected data from the British National Child Development Study (NCDS) to assess the long-term effects of childhood psychological and physical health problems on economic outcomes at ages $23,33,42$ and 50 . They find that childhood psychological problems are associated with about 15 percent lower hourly wages from early adulthood into middle age. They also show that the association of family income with psychological conditions is substantially larger than that with physical health 
conditions during childhood. ${ }^{2}$ Finally, Smith (2009) uses a subsample of U.S. siblings from the Panel Study of Income Dynamics (PSID) aged 25-47 in 1999 to estimate the associations of both childhood self-reported health (SRH) status and parental income during childhood with an individual's initial level of (annual) earnings at age 25 and its average growth between age 25 and age in 1999 . He finds that about 50 percent of their overall impact is already present at age 25 , while the remaining 50 percent is the consequence of faster individual income growth after age $25 .{ }^{3}$ However, a potential drawback of his analysis is that he focuses on (at most) two years of an individual's work career and that the oldest individuals in his sample are still relatively young from a life cycle perspective (namely, 47 years old).

The existing evidence regarding the effects of early life circumstances on employment is scarcer and also mixed. For example, Case et al. (2005) use data from a 1958 British birth cohort and report that the employment probability in mid adulthood is negatively associated with (early life) chronic conditions and positively associated with parental income at age 16. In contrast, Black et al. (2007) find that the positive association between birth weight and the probability of working full time in early adulthood disappears after controlling for twin fixed effects, and Smith (2009) reports no evidence of an association of childhood health with (annual) weeks worked at age 25, but a positive one with the change in weeks worked from age 25 onward. Goodman et al. (2011), for their part, find that childhood psychological problems are associated with about 11 percent lower employment probability from early adulthood into middle age.

\footnotetext{
${ }^{2}$ This latter finding, however, might also be related to the fact that some of the consequences of early life physical health conditions may become apparent later (that is, after age 50), as predicted by the fetal origins hypothesis (Barker 1995, Almond and Currie 2011b).

${ }^{3}$ Interestingly, when unobserved family effects are controlled for (using within-siblings estimates), the estimate of childhood SRH on post-25 individual income growth is substantially larger, which he attributes to a diminishing role of measurement error due to reporting bias in childhood SRH.
} 


\section{Data and descriptive statistics}

We use individual-level data from the first three waves of the Survey of Health, Aging, and Retirement in Europe (SHARE; http://www.share-project.org/), a multidisciplinary and representative cross-national panel of the European population aged 50 and over. The first two waves were conducted in 2004/2005 and 2006/2007 respectively. These waves include, for instance, information on sociodemographic background characteristics, current health and socioeconomic status (education, employment, and earnings), and expectations with regard to, e.g. retirement age. Most of our data, however, stem from the third wave, carried out in 2008/2009 and referred to as SHARELIFE. This third wave has collected retrospective information on the entire life histories of about 75 percent of the individuals who participated in waves 1 or 2 , which ranges from early life circumstances to work careers and other social, economic and health events occurring in the course of a lifetime. ${ }^{4}$ In our analysis, we combine this with cleaned information provided in the retrospective SHARE Job Episodes Panel Data. This retrospective panel contains the start and end dates of all the job spells that SHARELIFE respondents had during their work career, plus some job characteristics such as job income and whether they work full- or part-time, and some additional information on year of retirement and unemployment spells (see Brugiavini et al. (2013) for details). ${ }^{5}$

\footnotetext{
${ }^{4}$ Currently, four waves of SHARE data are available. The fourth wave does not contain information on (net) wages. However, we use wave 4 data to update and replace missing values for expectations with regard to retirement age for individuals who participated in waves 1 to 3 .

${ }^{5}$ SHARELIFE uses a life history calendar approach for collecting retrospective data. The PSID and the NCDS (used by Smith (2009) and Goodman et al. (2011) respectively) contain prospectively collected data, except for the retrospective childhood SRH measure in the PSID. In comparison with these two
} 
Our initial sample consists of 10,988 male and 13,154 female European

respondents (and spouses) aged 50 and over in the interview year of SHARELIFE. ${ }^{6} \mathrm{We}$ drop male and female respondents who had never worked or did not report any wage in SHARELIFE, nor in waves 1 or 2 (2,155 and 3,080 cases respectively), and also those who worked for less than five years (310 cases) to exclude individuals with very short employment histories. We also exclude male and female respondents for whom only one wage point is available $\left(1,379\right.$ and 1,454 cases respectively) ${ }^{7}$ Trimming compounded labor income by one percent from above and below in each country sets 304 values to missing. After dropping missing values in the childhood SES variables (429 cases), and childhood health variables (58 cases), we end up with our final sample of 7,803 male and 7,170 female respondents (and spouses) from the following thirteen countries: Sweden, Denmark, the Netherlands, Switzerland, Austria, Germany, France, Belgium, Spain, Italy, Greece, Czech Republic, and Poland. Table A.II reports the number of individuals, $\mathrm{N}$, by country and gender.

\section{Lifetime earnings}

We construct our measure of lifetime earnings in a similar way to Alessie et al. (2013). ${ }^{8}$ For each prior job spell, the retrospective SHARE Job Episodes Panel Data provides

studies, attrition bias is likely to be less of an issue in our study, although our (retrospective) data are likely to be less accurate. We return to this issue in Section 7.

${ }^{6}$ We do not restrict the sample to men as in previous studies such as Brunello et al. (2012).

${ }^{7}$ We exclude these respondents for practical reasons (see Appendix A.1). Because excluding all these individuals may introduce a selection bias into our analysis, we performed several robustness checks keeping these four groups in our sample. Our main results for childhood health and SES remain much unchanged for men, although not for women, which is however what one would expect as the sample workforce composition changes more for the latter (see Table A.I).

${ }^{8}$ We do not, however, include pension benefits in our measure of lifetime earnings. The reason for this is that we want to avoid a possible problem of double counting as would be the case if some pension benefits are funded by savings on (net) income from employment (see also Brunello et al. 2012). Weiss 
information about start and end dates, and the first net monthly wage or net income in nominal local currencies, depending on whether the respondent worked as an employee or as a self-employed during that job spell. If the respondent was retired by the time of interview, (s)he also reports the last net monthly wage in the main job or the last net monthly income from work if self-employed. We use linear interpolation between the first wage on each job and the last wage of the main job to obtain a complete wage path.

For those still working at the time of the SHARELIFE interview, we add the current net monthly wage (or the current net monthly income for the self-employed) in that year from the original SHARELIFE wave to the retrospective panel to use it as an additional point on the wage path. Similarly, we also add net monthly wages from waves 1 and 2, and net monthly income from wave 2 for the self-employed (not available in wave 1), to the retrospective job panel. ${ }^{9}$ During unemployment years, we assign the respondent a wage equal to 80 percent of his or her last earnings. We convert all earnings to annual PPP-adjusted German euros of 2006 as explained in Trevisan et al. (2011).

Our measure of compounded labor income at age $t$ is given by:

$$
L_{0 t}=\sum_{\tau=1}^{t}(1+r)^{t-\tau} E_{\tau}
$$

where $r$ is a constant real interest rate, and $E_{\tau}$ are annual earnings from employment at age $\tau$. Period 1 is the start of the work career, and we compound up to the SHARELIFE interview year for the non-retired, and the year before retirement (or the

(2012), who uses also SHARELIFE data, reports a correlation of 0.95 between lifetime earnings with and without pension benefits.

${ }^{9}$ We annualize earnings by multiplying monthly earnings by 12 (6) if the respondent works full-time (part-time). Earnings are annualized because employment spells are in years but weighted by $1(0.5)$ if the respondent works full-time (part-time). 
year of retirement if the individual reports to work in the year of retirement) for the retired using an annual real interest rate of two percent (Brunello et al. 2012; Haider and Solon 2006). After compounding, we have a cross-sectional dataset with one observation per individual.

For those individuals still working at the time of the SHARELIFE interview, we also calculate their future labor income:

$$
L_{1 t}=\sum_{\tau=t+1}^{R}(1+r)^{t-\tau} E_{\tau}
$$

We assume that future real annual earnings remain constant $\left(E_{\tau}=E_{t}, \tau=t+1, \ldots, R\right)$, and that retirement, $R$, starts in the year in which the individual reaches his or her expected retirement age, obtained from waves 1, 2, or 4 (more specifically, the age at which they expect to collect pension benefits), or the statutory retirement age (see Table A.III) in case of item non-response to that question. We use country- and gender-specific 2009 (period) life tables from Eurostat (http://epp.eurostat.ec.europa.eu/) to weight all future incomes by the survival probability. ${ }^{10,11}$

To sum up, for individuals who are retired at the time of the SHARELIFE interview, their lifetime earnings are measured by $L_{0 t}$, while for individuals who are still working, their lifetime earnings are the sum of $L_{0 t}$ and $L_{1 t}$. Table A.II shows sample statistics for average undiscounted annual earnings (computed as the sum of all annualized earnings from employment divided by years worked), ${ }^{12}$ by country and

\footnotetext{
${ }^{10}$ We use within-period survival probabilities, i.e. between age $t$ and $t+1$, and allow these to vary across country, gender and age. We assume the survival probabilities remain constant after 2009.

${ }^{11}$ In Section 6, we test and show the robustness of our findings to some of the assumptions that we make to construct our measure of lifetime earnings.

12 This variable is used for the descriptive analysis only.
} 
gender. The cross-country pattern of median earnings for men is very similar to that in Alessie et al. (2013, Table 1, pp. 314). Eastern European countries such as Poland and the Czech Republic have considerably lower annual earnings than Western European countries, while annual earnings are highest in Switzerland. Women's pattern of median annual earnings is somewhat less clear than that of men, but all in all similar: annual earnings are lowest in Eastern European countries and highest in Switzerland.

\section{Childhood SES}

For measuring childhood SES we use four variables that capture different dimensions of the respondent's SES at age 10. First, we include the number of rooms per person and the number of facilities in the household (including fixed bath, cold and hot running water supply, inside toilet and central heating), as these have been shown to be good proxies for the parents' financial status (Cavapozzi et al. 2011). Second, we consider the estimated number of books at home to capture the parents' cultural background or education (Cavapozzi et al. 2011). Last, we use the main breadwinner's occupation (in ISCO-88 skill levels) as a measure of the household's work status. We construct a single index of childhood SES using principal component analysis (PCA). We take the first principal component (PC), which explains the largest proportion of the total variance, as a measure of an individual's SES during childhood. We estimate the index using the pooled sample of all individuals in all thirteen European countries. The index explains 50.5 percent of the total variance and all the factor loadings on the first PC have the expected positive sign (see Table A.IV). 


\section{Childhood health}

For constructing a single index of childhood health we use a similar strategy as above for childhood SES. We combine subjective with self-assessed objective health measures referred to when the respondent was less than 16 years old to generate a childhood health index (HI) for each respondent. We use childhood SRH as our subjective health measure, and group the original six categories (from 1 to 6: excellent, very good, good, fair, poor, and changing) into four (from 1 to 4: excellent; very good; good; fair, poor, or changing). ${ }^{13}$ Among the objective health measures, we consider the number of respiratory problems, infectious diseases, cardiovascular diseases, neurological and psychiatric diseases, disorders of the sense organs, and the number of neoplastic diseases and other serious health conditions an individual suffers during childhood. ${ }^{14}$ We use PCA on the pooled sample and keep the first PC as a measure of an individual's childhood health (cf. Poterba et al. 2010). The index explains 20.2 percent of the total variance and all the factor loadings on the first PC have the expected positive sign (see Table A.V). The childhood HI is turned into an index of good health, and both indices are transformed into terciles.

\footnotetext{
13 The category "changing" includes 0.4 percent of the SHARELIFE sample and is recorded only if the respondent spontaneously answers that her childhood health varied a great deal.

${ }^{14}$ These count variables are constructed using the information in questions hs008 and hs009 in the SHARELIFE questionnaire, where respondents are asked to report on a yes or no basis whether they had 20 specific childhood diseases between their birth and age 15. In particular, respiratory problems include asthma, and other respiratory problems and allergies. Infectious diseases include also polio, severe diarrhea, meningitis/encephalitis, and appendicitis. Cardiovascular diseases include diabetes or high blood sugar, and heart trouble. Neurological and psychiatric diseases include severe headaches or migraines, and epilepsy, fits or seizures, and emotional, nervous or psychiatric problems. Disorders of the sense organs include chronic ear problems, speech impairment, and difficulty in seeing even with eyeglasses. Finally, other serious health conditions are combined with neoplastic diseases.
} 


\section{Additional controls}

We include dummies for birth year in all equations to control for possible secular or cohort-specific events that may have affected both an individual's early life circumstances and life cycle labor market behavior. Moreover, we include country dummies to control for institutional differences between European countries. ${ }^{15}$

\section{Early life circumstances and life cycle labor market outcomes}

\subsection{Early life circumstances and total lifetime earnings}

We first examine the associations of early life circumstances with the logarithm of lifetime earnings using linear regression models. As shown in Columns (1) in Table I, childhood SES is strongly associated with total lifetime earnings, and most notably for women. For instance, men and women with a low childhood SES (in the bottom tercile of childhood SES) earn, respectively, up to $27(\exp (0.241)-1)$ and 52 percent less income during their working life than individuals who had a high SES during childhood (those in the highest tercile of childhood SES). To a lesser extent, we also find a positive association with childhood health. Men and women with a low childhood HI (in the bottom tercile of childhood health) earn up to, respectively, 6 and 8 percent less income during their working life than those who had a high HI during childhood (in the highest tercile of childhood health).

Previous studies (Case et al. 2002; Currie and Stabile 2003) argue that income buffers children from the negative effects of chronic conditions (which are also more common among low-SES children); this is called the buffering hypothesis. Here, we test

\footnotetext{
${ }^{15}$ These additional controls are also of relevance to the use of the objective childhood health measures as there is a relatively large variation in response rates across countries, and some evidence of a negative association between age and reporting on these conditions. Importantly, however, there is no evidence of recall error in these health measures (Havari and Mazzonna 2011).
} 
this hypothesis for lifetime earnings. We therefore add interaction terms between the childhood health and SES terciles in Columns (2). In particular, we want to test whether having a higher SES during childhood reduces the negative correlation between lifetime earnings and poor health during childhood. If childhood SES has a protective effect, i.e. there is a buffering effect, we would expect the difference in lifetime earnings between persons with a high childhood $\mathrm{HI}$ and a low childhood HI to be smaller for persons with a high childhood SES than for persons with a low childhood SES. Hence, we test whether $\beta_{\text {HighHI }{ }^{*} \text { LowSES }}-\beta_{\text {LowHI }{ }^{*} \text { LowSES }}>\beta_{\text {HighHI }}{ }_{\text {HighSES }}-\beta_{\text {LowHI*HighSES, }}$ where the $\beta$ s are the regression coefficients corresponding to the variables in the subindex and $\beta_{\text {HighHI } * \text { HighSES }}=0$. As the bottom part of the table shows, we reject the null of no buffering effect of childhood SES for women but not for men.

$<$ Insert Table I about here $>$

\subsection{How does the association between early life circumstances and lifetime earnings evolve over the life cycle?}

As discussed in Section 2, Smith (2009) finds that the association of childhood health (and parental income) with individuals' (annual) earnings is larger when measured in their forties than at age 25 , which he argues is consistent with both the fact that some consequences of poor childhood health in terms of earlier adult life onset of disease do not appear until later in adult life and also that their impacts might be cumulative.

Goodman et al. (2011) show a similar increasing association of childhood psychological problems and (low) birth weight with family income between ages 23 and 50, and a rather constant one for summary indices of minor and major physical health problems. Our main advantage over Smith's study is that while he considers (at most) two years of 
an individual's work career, our data allows us to explore how these associations evolve over the whole work career of an individual. Hence, in contrast to Goodman et al. (2011), as well as investigating the associations with childhood SES, we also explore the period of over 50 years of age, which is when some of the consequences of early life physical health conditions may actually become apparent.

In particular, we estimate the associations of early life circumstances with the logarithm of lifetime earnings at different ages of men and women's working life (at five-year age intervals between the ages of 25 and 65). Our interest lies in understanding how the association between early life circumstances and lifetime earnings evolves over time until resulting in the correlations at the end of the working life shown in the previous section. Therefore, we focus our attention on the association with accumulated earnings until different ages instead of earnings at different ages, which is what previous studies — including Smith (2009) and Goodman et al. (2011) have done. ${ }^{16}$ The results are shown in Figure 1 and Table A.VI in the appendix.

Panel A in Figure 1 shows that, compared to men with a high childhood HI, those with a low and medium childhood HI accumulate significantly fewer earnings over their whole working life, but that these effects are not dramatic and remain more or less constant (between 6 and 9 percent). On the other hand, those with a low childhood SES accumulate more earnings at younger ages (around 26 percent $(\exp (0.230)-1)$ more at age 25), most likely because they start working earlier (see next section), but end up with about 27 percent lower lifetime earnings (at age 65) than men with a high

\footnotetext{
${ }^{16}$ This approach, we believe, might be more informative of the possible cumulative impacts that early life circumstances have on earnings. In the next section, we also present estimates on an individual's cumulative (average) annual earnings at different ages, which might be more comparable to the results of previous studies.
} 
childhood SES. Men with a high childhood SES have already caught up in (accumulated) earnings by their early thirties.

Panel B in Figure 1 shows that women with a low childhood HI present a similar pattern to that of men, and earn over most of the life cycle about 6-8 percent less income than women with a high childhood HI. This association, although not present at the beginning of their working life, becomes evident as early as age 25 . Instead, women with a medium and in particular a low SES during childhood start accumulating increasingly fewer earnings over their working life at an earlier age than their male counterparts, as early as age 30 . Compared to women with a high childhood SES, those with a low childhood SES already accumulate 21 percent fewer earnings at age 30 and end up with 52 percent $(\exp (0.421)-1)$ lower lifetime earnings at age 65 .

$<$ Insert Figure 1 about here $>$

Panels A and B in Figure 2 show the same picture for men and women respectively, but with the interaction terms needed for testing the buffering hypothesis in lifetime earnings $\left(\beta_{\text {HighHI }}{ }^{\text {LowSES }}-\beta\right.$ LowHI*LowSES $>\beta_{\text {HighHI }}{ }^{*}$ HighSES $-\beta$ LowHI*HighSES $)$ over the working life (the full set of estimates are available in Table A.VII in the appendix). The pattern of lifetime earnings over the life cycle for men who had a low childhood SES compared to men with a high childhood SES is similar for those who were in the top or bottom part of the childhood health distribution. Therefore, we find no evidence of a buffering effect (see Table A.VII). In contrast, for women the negative effect of having a low SES during childhood is larger for those who also had a low childhood HI compared to those with a low childhood SES but a high childhood HI, and this difference increases over the life cycle. In fact, we find evidence that parental SES buffers (part of) the negative effect of childhood health on lifetime earnings in the oldest age intervals, 55-60 and 60-65 (see Table A.VII). 
$<$ Insert Figure 2 about here $>$

\subsection{What is the implicit labor market behavior in the association between early life circumstances and lifetime earnings over the life cycle?}

Our previous results show that the associations of childhood health and SES with (accumulated) earnings vary over an individual's life cycle, and that there are some differences between men and women. The evolution of lifetime earnings over the life cycle depends on how the number of years worked and/or the average annual earnings evolve. ${ }^{17}$ Therefore, to better understand the labor market behavior behind the associations of early life circumstances with lifetime earnings, we further analyze whether early life circumstances are correlated with the number of years worked and with annual earnings. This will shed light on whether the (cumulative) association of early life circumstances with accumulated lifetime earnings operates through working years and/or through average annual earnings.

We estimate linear models for the associations of early life circumstance with the logarithm of (accumulated) years worked and the logarithm of (average) annual earnings. The estimates for the bottom SES and health terciles are shown in Figures 3 and 4 respectively for men and women (the full set of estimates can be found in Tables A.VIII and A.IX in the appendix). As shown in Figure 3, men and women with a low childhood SES start working earlier, but during their working life individuals with a high childhood SES catch up, and women with a low childhood SES actually end up working fewer years than those with a high childhood SES. Men and women with a low childhood SES also have, respectively, about $23(\exp (0.208)-1)$ and 39 percent lower

\footnotetext{
${ }^{17}$ The logarithm of lifetime earnings is approximately equal to the logarithm of years worked plus the logarithm of annual earnings.
} 
annual earnings at age 25. But while for women this difference remains constant over their working life, for men it increases to more than 30 percent in their mid thirties and remains constant afterwards. These results suggest that the pattern (i.e. the different magnitudes and even different signs) in the association between childhood SES and lifetime earnings over the life cycle is driven by working years rather than by (average) annual earnings. Moreover, men from a lower childhood SES background compensate to some extent their lower annual earnings by working more years.

Figure 4 shows that, although to a lesser extent, also men with a low childhood health have lower annual earnings, but do not work significantly less over their working life than those with a high childhood health. For their part, women with a low childhood health also have lower annual earnings, although over a shorter age interval (from about age 30 to age 50), and in addition work significantly less after age 40. However, in contrast to the results for childhood SES, the difference in average annual earnings for individuals with a high and low childhood health shrinks over time; for men from 9 percent at age 25 to 5 percent at age 50 and over, and for women it even becomes insignificant from age 50 onward. Hence, while for men the association between childhood health and lifetime earnings over the life cycle operates through average annual earnings rather than through working years, for women, this association appears to be driven by annual earnings from their early thirties to mid forties and mainly by the number of years worked after age 50 .

$<$ Insert Figures 3 and 4 about here $>$

The previous figures have shown that individuals from a low-SES background accumulate a larger number of working years at the beginning of their working life and that this difference declines over time. Moreover, the evolution over the life course differs by gender so that women and men in the lowest SES tercile end up working at 
the end of their careers almost 10 percent fewer and 5 percent more years than their peers from the highest tercile respectively. This suggests that individuals with a low childhood SES may have more employment gaps during their working life and/or are more likely to leave the labor market earlier than individuals with a high childhood SES. In addition, the explanation may be different for men and women.

Figures 5 and 6 present estimates for the bottom health and SES terciles on the accumulated number of career gaps ${ }^{18}$ and on the probability of leaving the labor market over the life cycle, respectively, for both men and women (the full set of estimates can be found in Tables A.X and A.XI in the appendix). The difference in the number of career gaps between low- and high-childhood SES individuals is larger among women. Those with a low childhood SES accumulate more gaps from the beginning of their working life and the difference increases from around 2 gaps at age 25 to 5 gaps at age 55 , and diminishes after age 60 , although it remains as high as 4.6 career gaps at the end of their working life. The pattern is similar for men, although the largest estimated marginal effect is about 1.6. These results can explain to some extent why the negative association between childhood SES and working years diminishes over the life cycle.

On top of this, estimates from simple linear probability models (Figure 6) show that men and women with a low childhood SES are not more likely to leave the labor market before age 50 than individuals with high childhood SES. However, men, and to a lesser extent also women, are more likely to early-retire from that age onward than individuals with a high childhood SES.

Women with a low childhood health also accumulate significantly more career gaps during their late twenties and during their thirties (see Figure 5) and in addition

\footnotetext{
${ }^{18}$ As there is a large number of individuals without career gaps, we estimate Tobit models and present marginal effects in Figure 5.
} 
have a higher probability of leaving the labor market until age 50 (see Figure 6) than women who had a high childhood health. For men we do not find such associations.

$<$ Insert Figures 5 and 6 about here $>$

\section{Are there differences between country-groups in life cycle profiles?}

In the previous analyses, we have assumed that labor market responses over the life cycle to childhood health and SES are homogeneous across our sample of European countries. However, there are large cross-country differences in the levels of development over the period in which the individuals in our sample were born and raised. These large differences in economic resources and access to medical treatments may affect the associations between early life circumstances and later life outcomes as a more favorable environment in this respect may dampen the consequences of adverse health shocks early in life (Bengtsson and Mineau 2009). Moreover, equality of opportunities in educational attainment and social protection policies may enhance the intergenerational income mobility, and therefore we would expect a lower association between childhood SES and lifetime earnings in more egalitarian countries.

We investigate these conjectures more closely by allowing the estimates to differ between four groups of countries: i) Nordic (Sweden and Denmark), ii) Continental (Netherlands, Switzerland, Austria, Germany, France and Belgium), iii) Mediterranean (Spain, Italy and Greece) and iv) Transitional (Czech Republic and Poland). We use the country-group-specific distributions of childhood SES and health (instead of the distribution from the pooled sample) to create the terciles of childhood SES and health to ensure that these are equally distributed within country-groups. Figures 7 to 9 show estimates for low childhood HI and low childhood SES on the logarithm of lifetime earnings, the logarithm of years worked and the logarithm of (average) annual earnings 
respectively (the full set of estimates can be found in Tables A.XII to A.XIV in the appendix).

It is mostly in the Mediterranean countries that individuals with a low childhood health accumulate fewer earnings during their work career, and to some extent also for men in Nordic and women in Continental countries. Moreover, while for Mediterranean men most of this association is already present early in their working life, for Mediterranean women it tends to kick in a bit later, but is also larger and slightly increasing with age (Panels A and B in Figure 7). To illustrate this, Mediterranean women with a lower childhood health accumulate 20 percent $(\exp (0.184)-1)$ fewer lifetime earnings at age 35 , which increases to about 26 percent at age 65 . For Mediterranean men, these differences at age 35 and 65 are about the same (17 and 16 percent respectively).

Although for men the profiles of the association between low childhood SES and earnings over the life cycle are similar in all country-groups (Panel C in Figure 7), only in Continental and Mediterranean countries do those with a low childhood SES accumulate significantly more earnings at younger ages (29 and 18 percent respectively at age 25). At age 65, however, those with a low childhood SES have between 20 and 30 percent lower lifetime earnings in all country-groups. Instead, for women, these profiles are more heterogeneous across country-groups (Panel D in Figure 7). For instance, at age 35 the magnitude of the association between childhood SES and lifetime earnings is largest in Continental and Transitional countries, where women with a low childhood SES have about 40 percent lower lifetime earnings than women with a high childhood SES. But from that age onward, it is women with a low childhood SES from Continental and Mediterranean countries who accumulate increasingly lower lifetime earnings. At age 65, these women have about 59 percent lower lifetime 
earnings than their female peers with a high childhood SES, a difference that falls to 26 and 35 percent for women from Nordic and Transitional countries respectively.

$<$ Insert Figure 7 about here $>$

To better understand the implicit labor market behavior that may cause these associations across country-groups, we further analyze whether early life circumstances are correlated with (average) annual earnings (Figure 8) and (accumulated) working years (Figure 9). Within country-groups, and for both men and women, the profiles of the associations of childhood health and childhood SES with (average) annual earnings remain quite constant over the life cycle (Figure 8). However, across country-groups there are some differences in the magnitude and significance of these estimates. For example, it is in the Mediterranean countries, and mostly from the beginning of their working life, that individuals with a low childhood health have lower (average) annual earnings (Panels A and B in Figure 8). On the other hand, it appears that in all countrygroups men and women with a low childhood SES accumulate lower annual earnings during their working life (Panels $\mathrm{C}$ and $\mathrm{D}$ in Figure 8); these estimates are largest for women from Continental countries.

$<$ Insert Figure 8 about here $>$

Only for women from Mediterranean and Transitional countries is there some evidence of a negative association between having a low childhood health and working years over the life cycle (Panels A and B in Figure 9). These associations are not apparent at the beginning of their working life, but at age 65 women with a low childhood health in Mediterranean and Transitional countries have worked 11 and 5 percent fewer years respectively than those with a high childhood health. Also, in all country-groups men and women with a low childhood SES start working earlier, but 
individuals with a high childhood SES catch up, although the gap only disappears for men and women from Transitional countries, and for women from Nordic countries (Panels $\mathrm{C}$ and D in Figure 9). Furthermore, the difference in the number of years worked between socioeconomic groups switches sign for women from Continental and in particular from Mediterranean countries, where women with a low childhood SES end up working fewer years than those with a high childhood SES.

$<$ Insert Figure 9 about here $>$

\section{Robustness of the results}

Table II shows the results of several sensitivity analyses. We present estimates for the bottom health and SES terciles obtained from estimating linear models on the logarithm of lifetime earnings of men and women in Europe, together with the R-squared and the number of observations (the full estimation results are available upon request). To facilitate comparison, we repeat in Row 0 our main estimation results from Table I.

First, we tested the robustness of our results to the method and sample used to construct our indices of childhood health and SES. In Row 1, Table II, we present estimates when using the polychoric correlation matrix to perform the PCA, which takes into account the discrete nature of some of the variables used to measure childhood SES (number of facilities, number of books and main breadwinner's occupation) and childhood health (childhood SRH and number of several objective health conditions). The variance explained by the first principal component slightly increases in this case (to 0.288 for childhood health and 0.529 for childhood SES), but the estimation results 
remain unchanged. ${ }^{19}$ The results in Row 2 show that using country- and gender-specific distributions to construct the terciles of childhood SES and childhood HI do not affect our main estimation results.

Second, we tested the influence of some of our assumptions for constructing our measure of lifetime earnings. In Row 3 we exclude those individuals who have been self-employed at any stage during their working life, and obtain similar results. The results are also robust to not adjusting for differences in working hours when constructing our measure of lifetime earnings (Row 4); ${ }^{20}$ and they are also robust to assigning no unemployment benefits during unemployment spells instead of 80 percent of the previous wage (Row 5).

Third, as one could be concerned about the influence of possible extreme values due to measurement error in our measure of lifetime earnings, we exclude Greece and Poland from our sample as these two countries have rather high (undiscounted) annual lifetime earnings (see Table A.II), which may seem unreliable and could cast doubt on the validity of our analysis. This exclusion does not change our main results (see Row 6). Similarly, because the cross-country distribution of median lifetime earnings shown in Table A.II may appear more reliable than the distribution of mean values that might be influence by outliers, we use median regression to estimate the log lifetime earnings equations, and obtain again similar results (see Row 7).

Finally, because some studies have used height as an indicator for early life circumstances to explore the height premium in earnings that is typically observed in

\footnotetext{
${ }^{19}$ This finding is supported by Kolenikov and Angeles (2009), who show the relevance of using the polychoric correlation matrix when performing the PCA on dichotomous variables rather than on ordinal (and continuous) variables, as is our case.

${ }^{20}$ This increases the female sample somewhat, as fewer observations are dropped because of working less than five years (see Section 3).
} 
adulthood, ${ }^{21}$ we re-estimate our main models for lifetime earnings controlling also for self-reported height (at the time of the SHARELIFE interview). As shown in Row 8, the estimates for the bottom childhood health and SES terciles remain virtually the same, which suggests that the association of these early life circumstances with lifetime earnings is not mediated through height. ${ }^{22}$ All in all, none of these sensitivity analyses changes the main results and conclusions of our paper.

\section{Summary and discussion}

To the best of our knowledge, this study is the first to investigate how early life circumstances - as measured by two indices of childhood health and socioeconomic status (SES) - are associated with earnings and other labor market outcomes over the entire life cycle. In particular, we focus on accumulated earnings, average annual earnings, number of years worked, number of career gaps, and the timing of retirement. The analysis is conducted using data from the Survey of Health, Aging and Retirement in Europe, which contains retrospective information on respondent's early life circumstances and full work histories.

Our results show that in general childhood SES has a larger impact on individual's life cycle labor market outcomes than childhood health, and most notably for women. For instance, men and women with a low childhood SES earn, respectively, up to 27 and 52 percent less income during their working life than individuals with a high SES during childhood. These differences fall to 6 and 8 percent respectively when we compare men and women with a low and high childhood health. But our results also

\footnotetext{
${ }^{21}$ For instance, Case and Paxson (2008) use height (at various ages) to examine the role of (childhood) cognitive ability as a possible channel through which the height premium in earnings operates.

${ }^{22}$ The coefficient for a 10 centimeter increase in height with standard error in parentheses is $0.063(0.012)$ for men and $0.045(0.018)$ for women.
} 
show that these associations, and especially those with childhood SES, are not constant over the life cycle. While women with a low childhood SES accumulate increasingly fewer earnings almost from the beginning of their working life (21 percent less as early as age 30 ), men with a low childhood SES accumulate significantly more earnings up to that age (still about 9 percent more at age 30). These associations operate through annual earnings, which show a persistent, fairly constant effect during working life that favors individuals with a high childhood SES, but also through working years. This latter effect, instead, favors at the beginning of the working life individuals with a low childhood SES (who start working earlier), but diminishes thereafter when these individuals accumulate more career gaps than individuals with a high childhood SES. For women, the association between childhood SES and working years even reverses sign after age 45 , favoring women with a high childhood SES. With regard to childhood health, its smaller, fairly persistent, positive long-term association with lifetime earnings appears to operate through (lower) annual earnings rather than through working years, except for women.

Hence, our results for working years are to some extent in line with Smith's (2009) finding of a positive association between childhood health and earnings that operates in part through a greater adult work effort. However, we show that this finding of Smith is driven by women who had a worse health during childhood and, moreover, that this positive association becomes significant after age 40 . In addition, we show that while for men the association between childhood health and lifetime earnings is already present at the beginning of their working life (at age 25), for women it kicks in just after that age.

Our additional results also point to some differences in these life cycle profiles across European country-groups. For instance, the relatively small and positive long- 
term association between childhood health and earnings over the life cycle is mainly present in the Mediterranean countries. On the other hand, the relatively strong cumulative impact of childhood SES on earnings over the life cycle is present in all country-groups and for men and women. Nevertheless, for women most of the life cycle profiles (for instance, those with accumulated earnings) are larger in the Mediterranean and Continental countries than in Nordic and Transitional countries. Also for women only, we find evidence of a buffering effect, i.e. that a higher parental SES reduces the negative impact of poor health during childhood on lifetime earnings.

A question that arises when interpreting the relatively larger impact of childhood SES on life cycle labor market outcomes when compared to that of childhood health is whether this is due to measured changes in childhood SES being more severe than those in childhood health. Our descriptive evidence does not support this hypothesis. Although individuals in the bottom tercile of the distribution of childhood SES lived, on average, in relatively small and badly equipped houses (with 0.48 rooms per person and 56 percent having none of the facilities included in Table A.IV), with few books (98 percent did not have enough books to fill one bookcase), and predominantly with a lowskilled breadwinner (for 39 percent the main breadwinner worked in a low-skilled occupation), ${ }^{23}$ also the shift from the highest to the lowest tercile of childhood health is large, and possibly even more extreme. Basically, it implies comparing individuals who on average suffered from none of the conditions listed in Table A.V (except for infectious diseases) and without anyone reporting a poor, fair or changing childhood health with individuals who to some extent suffered from all these conditions (19 percent from respiratory problems, 2 percent from cardiovascular diseases, 13 percent from neurological and psychiatric diseases, 13 percent from disorders of the sense

\footnotetext{
${ }^{23}$ These numbers for individuals with a high childhood SES are respectively, 1, and 1, 16, and 5 percent.
} 
organs, 14 percent from neoplastic and other serious health conditions) and with 22 percent reporting a fair, poor or changing childhood health. Hence, a more plausible explanation for the larger associations with childhood SES could be that children are exposed for a longer period to their parents' SES than to any specific health condition. ${ }^{24}$

Further research could extend our analyses to assess the causal effects of early life circumstances on labor market outcomes over the entire life cycle and shed light on the underlying mechanisms that drive these relationships. This will make it possible to assess the influence of confounding factors ${ }^{25}$ in the results presented here and show how the causal effects and underlying mechanisms found elsewhere evolve over the life cycle. For instance, Maccini and Yang (2009) provide suggestive evidence that the causal effect of weather conditions early in life — measured by birth year rainfall—on the adult SES of Indonesian women is mediated more strongly by schooling attainment, and not as importantly by adult health. Also Brunello et al. (2012) find that the longterm association between access to books in the parental home and lifetime earnings for men in Europe is in part mediated through educational attainment. Flores and Kalwij (2014), for their part, find that the significant associations of favorable early life

\footnotetext{
${ }^{24}$ Neither can we rule out the possibility of measurement error being more severe in our measure of childhood health due to an underreporting in some of the health conditions and possible reporting bias in childhood SRH (Smith 2009). Together with previous lack of evidence of coloring bias (i.e. the response to childhood health questions being influenced by a worsening in current health status) in childhood SRH (Smith 2009) and in childhood attention deficit/hyperactivity disorders (Fletcher 2014), we would expect this to result in an attenuation bias. Other typical problems in this context such as differential mortality, which causes individuals from disadvantaged social backgrounds to be less likely to reach the age of 50 (and be in our panel), or parental efforts to compensate the negative effects of childhood health problems may — if anything — also attenuate our estimates of childhood health (and SES) towards zero (Currie 2009; Palloni et al. 2009).

${ }^{25}$ These could include (inherited) factors that are correlated with family background and which are rewarded in the labor market such as cognitive skills (Case and Paxson 2008), social skills (Persico et al. 2004) and other noncognitive skills related to personality (Lundborg et al. 2014; Mueller and Plug 2006), and beauty (Scholz and Sicinski 2014).
} 
circumstances with a higher incidence of later life employment are transmitted mostly through both education and later life health. Goodman et al. (2011) and Smith (2009) also show that part of the negative impact of adverse health during childhood operates through marriage markets, as individuals with childhood (mental) health conditions are less likely to get married, and if they do, they are less likely to stay with the same partner or their partner is less likely to work.

All in all, our empirical findings show that following a life cycle approach like ours is important because-as some theoretical models stipulate (e.g. fetal origins hypothesis and life course models) and our results confirm-some consequences of adverse (health) events early in life may not become apparent until later in adult life and because some of their impacts, in particular those related to childhood SES, may change and accumulate over the life cycle. Our findings also shed light on the potential gains in terms of different labor market outcomes for public policies that invest in children's health and parents' SES. Therefore, we show the importance of considering the possibility that the effects of poor health during childhood on lifetime earnings are larger for some groups (in our case, women from a lower SES background). Finally, our results also help in identifying who is more likely to leave the labor market at earlier ages, which can facilitate the design of policies aimed at attaining higher labor market participation rates over the life cycle.

\section{Acknowledgments}

The SHARE data collection has been primarily funded by the European Commission through the 5th Framework Program (project QLK6-CT-2001-00360 in the thematic program Quality of Life), through the 6th Framework Program (projects SHARE-I3, RII-CT-2006-062193, COMPARE, CIT5-CT-2005-028857, and SHARELIFE, CIT4- 
CT-2006-028812), and through the 7th Framework Program (SHARE-PREP, N ${ }^{\circ}$

211909, SHARE-LEAP, $\mathrm{N}^{\circ} 227822$ and SHARE M4, $\mathrm{N}^{\circ}$ 261982). Additional funding is also gratefully acknowledged from the U.S. National Institute on Aging (U01 AG09740-13S2, P01 AG005842, P01 AG08291, P30 AG12815, R21 AG025169, Y1AG-4553-01, IAG BSR06-11 and OGHA 04-064) and the German Ministry of Education and Research, as well as from various national sources (see http://www.share-project.org/ for a full list of funding institutions). We use release 2.6.0 of waves 1 and 2, and release 1 of wave 3 (SHARELIFE). We also use data from the generated job episodes panel; for methodological details see the SHARE working paper 11-2013 "Working life histories from SHARELIFE: a retrospective panel” by Brugiavini, Cavapozzi, Pasini and Trevisan.

We gratefully acknowledge financial support from Asociación Española de Economía de la Salud and Química Farmacéutica Bayer through the XXII Beca de Investigación en Economía y Salud for the project "The effects of early life circumstances over the life-cycle: A European cross-country comparison”. Pilar GarcíaGómez is a Postdoctoral Fellow of the Netherlands Organization for Scientific Research-Innovational Research Incentives Scheme-Veni. We also wish to thank Peter van Santen for sharing his do-files for constructing our measure of lifetime earnings, and Rob Alessie, Bob Haveman, Sergi Jiménez, John Mullahy, Giacomo Pasini, Elisabetta Trevisan, Bobbi Wolfe, and the seminar participants at University of Wisconsin-Madison, University of Southern California, City University London, $\mathrm{Ca}$ Foscari University of Venice, RWI Essen, the 2014 Netspar International Pension Workshop in Amsterdam, the 4th SHARE user conference, the 33rd Jornadas de la Asociación de Economía de la Salud, and the 10th Jornadas de la Asociación Española de Economía del Trabajo for valuable comments and discussions. Responsibility for the 
contents lies with the authors and does not represent the views of the OECD or the Governments of OECD member countries.

\section{References}

Alessie R, Angelini V, van Santen P (2013) Pension wealth and household savings in Europe: Evidence from SHARELIFE. European Economic Review 63: 308-328 Almond D (2006) Is the 1918 Influenza Pandemic over? Long-term effects of in utero influenza exposure in the post-1940 U.S. population. Journal of Political Economy 114: 672-712

Almond D, Currie J (2011a) Human capital development before age five. In: Ashenfelter O, Card D (eds) Handbook of Labor Economics, vol 4B, chap. 15. Elsevier, Amsterdam, pp 1315-1486

Almond D, Currie J (2011b) Killing me softly: The Fetal Origins Hypothesis. Journal of Economic Perspectives 25: 153-172

Barker DJP (1995) Fetal origins of coronary heart disease. British Medical Journal $311: 171-174$

Behrman JR, Rosenzweig MR (2004) Returns to birthweight. Review of Economics and Statistics 86: 586-601

Behrman JR, Wolfe BL (1984) The socioeconomic impact of schooling in a developing country. Review of Economics and Statistics 66: 296-303

Bengtsson T, Mineau GP (2009) Early-life effects on socio-economic performance and mortality in later life: A full life-course approach using contemporary and historical sources. Social Science and Medicine 68: 1561-1564 
Black SE, Devereux PJ (2011) Recent developments in intergenerational mobility. In: Ashenfelter O, Card D (eds) Handbook of Labor Economics, vol 4B, chap. 16. Elsevier, Amsterdam, pp 1487-1541

Black SE, Devereux PJ, Salvanes KG (2007) From the cradle to the labor market? The effect of birth weight on adult outcomes. Quarterly Journal of Economics 122: $409-439$

Bratberg E, Nilsen OA, Vaage K (2008) Job losses and child outcomes. Labour Economics 15: 591-603

Brugiavini A, Cavapozzi D, Pasini G, Trevisan E (2013) Working life histories from SHARELIFE: A retrospective panel. SHARE Working Paper 11-2013

Brunello G, Weber G, Weiss CT (2012) Books are forever: Early life conditions, education and lifetime income. IZA Discussion Papers 6386

Case A, Fertig A, Paxson C (2005) The lasting impact of childhood health and circumstance. Journal of Health Economics 24: 365-389

Case A, Lubotsky D, Paxson C (2002) Economic status and health in childhood: The origins of the gradient. American Economic Review 92: 1308-1334

Case A, Paxson C (2008) Stature and status: Height, ability, and labor market outcomes. Journal of Political Economy 116: 499-532

Cavapozzi D, Garrouste C, Paccagnella O (2011) Childhood, schooling and income inequality. In: Börsch-Supan A, Brandt M, Hank K, Schröder M (eds) The individual and the welfare state. Life histories in Europe, Chap. 3. Springer, Heidelberg, pp 31-43

Chen Y, Zhou L-A (2007) The long-term health and economic consequences of the 1959-1961 famine in China. Journal of Health Economics 26: 659-681 
Currie J, Stabile M (2003) Socioeconomic status and health: Why is the relationship stronger for older children? American Economic Review 93: 1813-1823

Currie J (2009) Healthy, wealthy, and wise: Socioeconomic status, poor health in childhood, and human capital development. Journal of Economic Literature 47: 87-122

Fletcher JM (2014) The effects of childhood ADHD on adult labor market outcomes. Health Economics 23: 159-181

Flores M, Kalwij A (2014) The associations between early life circumstances and later life health and employment in Europe. Empirical Economics 47: 1251-1282

Goodman A, Joyce R, Smith JP (2011) The long shadow cast by childhood physical and mental problems on adult life. Proceedings of the National Academy of Sciences 108: 6032-6037

Haider S, Solon G (2006) Life-cycle variation in the association between current and lifetime earnings. American Economic Review 96: 1308-1320

Havari E, Mazzonna F (2011) Can we trust older people's statements on their childhood circumstances? Evidence from SHARELIFE. SHARE Working Papers 05-2011

Heckman JJ, Hotz VJ (1986) An investigation of the labor market earnings of Panamanian males evaluating the sources of inequality. Journal of Human Resources 21: 507-542

Kolenikov S, Angeles G (2009) Status measurement with discrete proxy variables: Is principal component analysis a reliable answer? Review of Income and Wealth 55: $128-165$

Kuh DJL, Wadsworth MEJ (1993) Physical health status at 36 years in a British national birth cohort. Social Science and Medicine 37: 905-916 
Lam D, Schöeni RF (1993) Effects of family background on earnings and returns to schooling: Evidence from Brazil. Journal of Political Economy 101: 710-740

Lundborg P, Nystedt P, Rooth D-O (2014) Height and earnings: The role of cognitive and noncognitive skills. Journal of Human Resources 49: 141-166

Maccini S, Yang D (2009) Under the weather: Health, schooling, and economic consequences of early-life rainfall. American Economic Review 99: 1006-1026

Mueller G, Plug E (2006) Estimating the effect of personality on male and female earnings. Industrial and Labor Relations Review 60: 3-22

Nelson RE (2010) Testing the Fetal Origins Hypothesis in a developing country: Evidence from the 1918 Influenza Pandemic. Health Economics 19: 1181-1192

Oreopoulos P, Page ME, Stevens AH (2008) The intergenerational effects of worker displacement. Journal of Labor Economics 26: 455-483

Palloni A, Milesi C, White RG, Turner A (2009) Early childhood health, reproduction of economic inequalities and the persistence of health and mortality differentials. Social Science and Medicine 68: 1574-1582

Persico N, Postlewaite A, Silverman D (2004) The effect of adolescent experience on labor market outcomes: The case of height. Journal of Political Economy 112: $1019-1053$

Poterba JM, Venti SF, Wise DA (2010) The asset cost of poor health. NBER Working Paper 16389

Scholz JK, Sicinski K (2014) Facial attractiveness and lifetime earnings: Evidence from a cohort study. Review of Economics and Statistics. DOI:

10.1162/REST_a_00435

Smith JP (2009) The impact of childhood health on adult labor market outcomes. Review of Economics and Statistics 91: 478-489 
Trevisan E, Pasini G, Rainato R (2011) Cross-country comparison of monetary values from SHARELIFE. SHARE Working Paper 02-2011

Weiss CT (2012) Two measures of lifetime resources for Europe using SHARELIFE. SHARE Working Paper 06-2012 
Figure 1. Estimates from log lifetime earnings regressions over the life cycle $\mathbf{I}^{\mathrm{a}}$

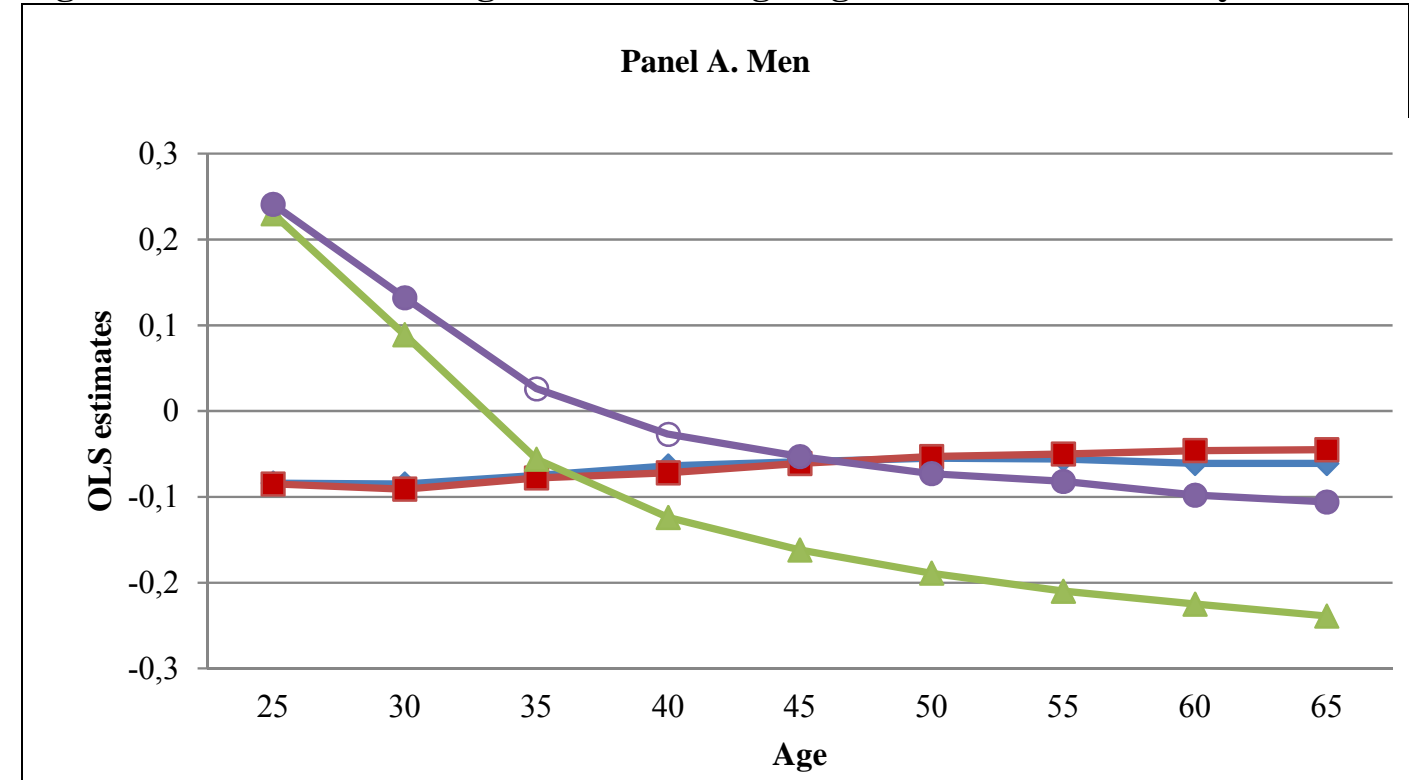

Panel B. Women

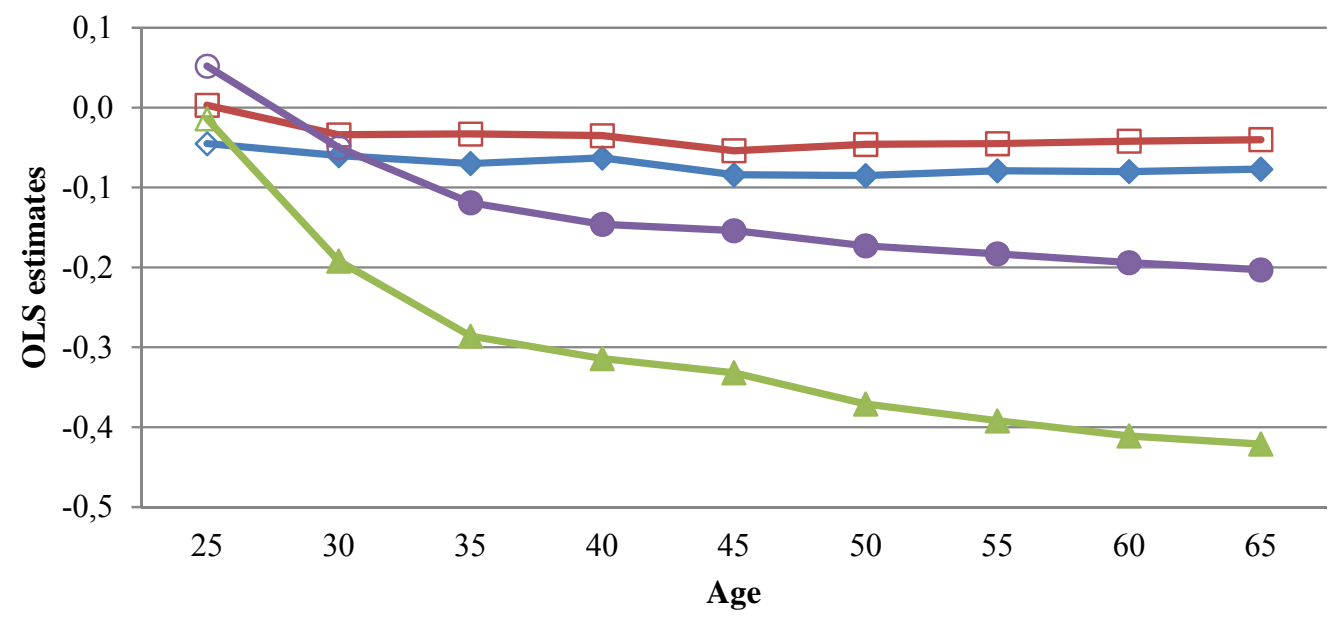

$\longrightarrow$ Low childhood $\mathrm{HI} \rightarrow$ Medium childhood HI $\rightarrow$ Low childhood SES $\longrightarrow$ Medium childhood SES

a The figure shows OLS estimates for Low and Medium childhood HI and Low and Medium childhood SES obtained from estimating linear models on the logarithm of accumulated earnings at different ages over an individual's working life. The reference categories are, respectively, High childhood HI and High childhood SES. All models include country dummies and birth-year dummies. A solid square, diamond, triangle or dot indicates significance at a $5 \%$ level based on robust standard errors. 
Figure 2. Estimates from log lifetime earnings regressions over the life cycle II $^{\mathrm{a}}$

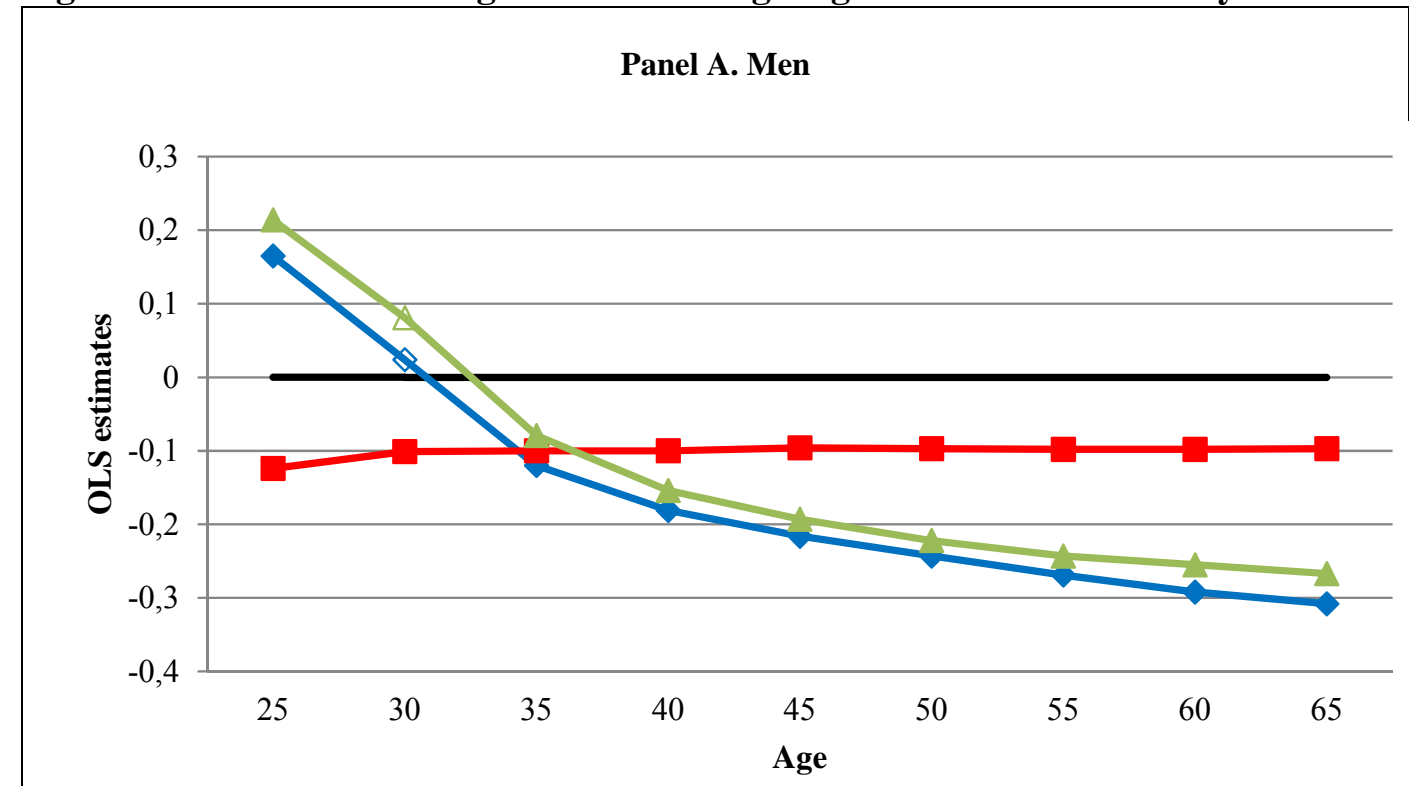

Panel B. Women

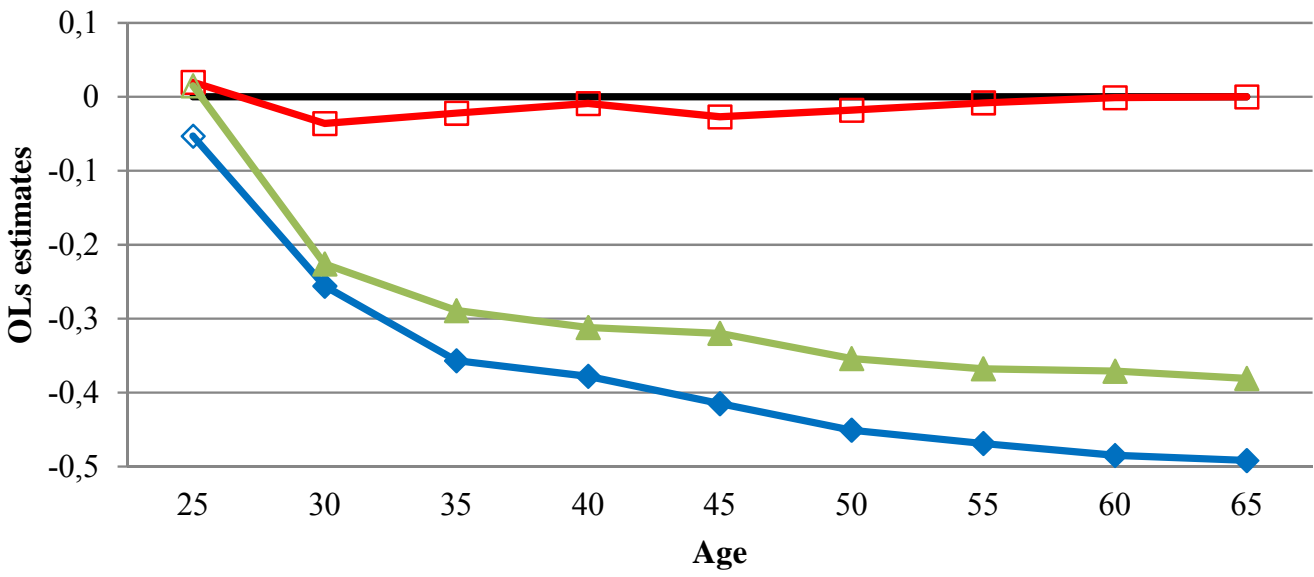

$\longrightarrow$ High HI x High SES $\sim$ Low HI x Low SES $\neg$ Low HI x High SES $\neg$ High HI x Low SES

a The figure shows OLS estimates only for the interaction terms needed to compute the buffering hypothesis $\left(\beta_{\text {HighHI*LowSES }}-\beta_{\text {LowHI }{ }^{*} \text { LowSES }}>\beta_{\text {HighHI*HighSES }}-\beta_{\text {LowHI*HighSES }}\right)$ obtained from estimating linear models on the logarithm of accumulated earnings at different ages over an individual's working life (the reference category High HI x High SES is represented by the bold zero line). All models include country dummies and birth-year dummies. A solid square, diamond or triangle indicates significance at a $5 \%$ level based on robust standard errors. The full estimation results are in the appendix. 
Figure 3. Estimates for low childhood SES from regressions on log average annual earnings and log years worked over men and women's life cycle ${ }^{a}$

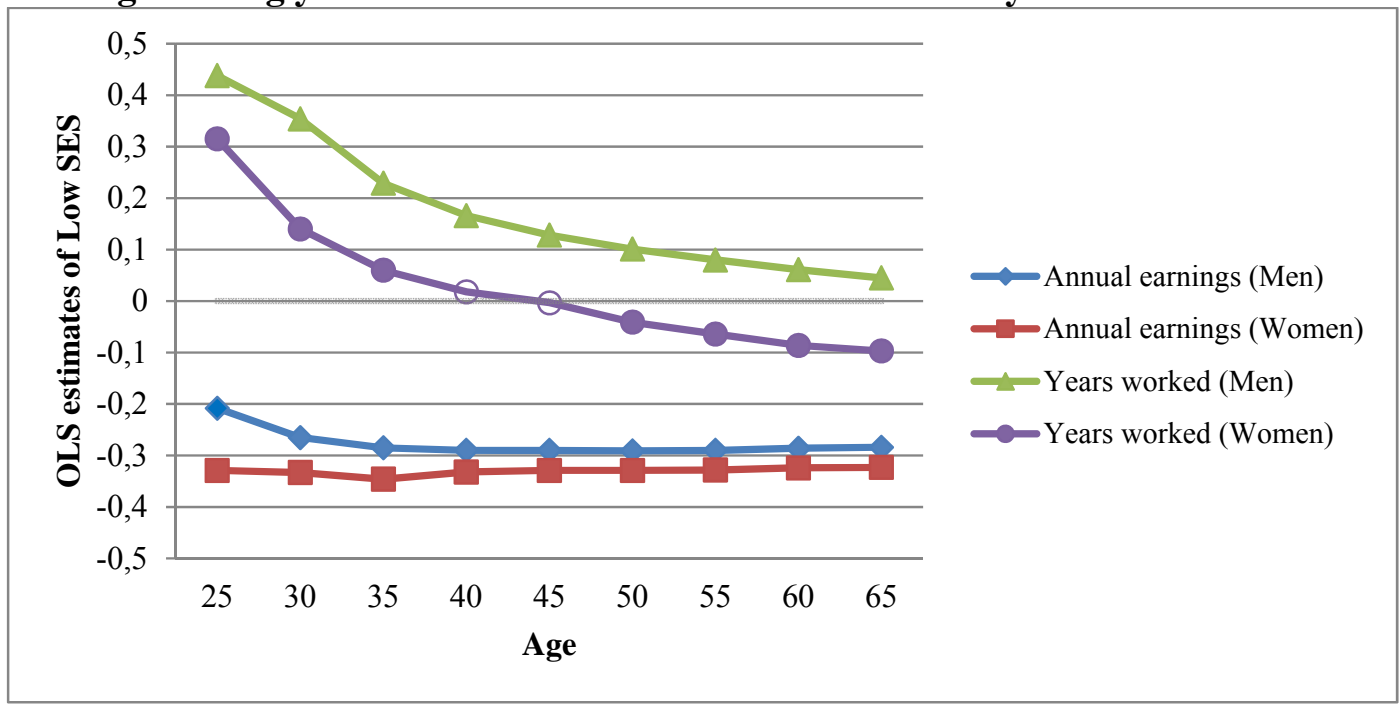

a The figure shows OLS estimates for Low childhood SES obtained from estimating linear models on the logarithm of (average) annual earnings and the logarithm of (accumulated) years worked at different ages over an individual's working life. The reference category is High childhood SES. All models include country dummies and birth-year dummies. A solid square, diamond, triangle or dot indicates significance at a $5 \%$ level based on robust standard errors.

Figure 4. Estimates for low childhood health from regressions on log average annual earnings and log years worked over men and women's life cycle ${ }^{\mathrm{a}}$

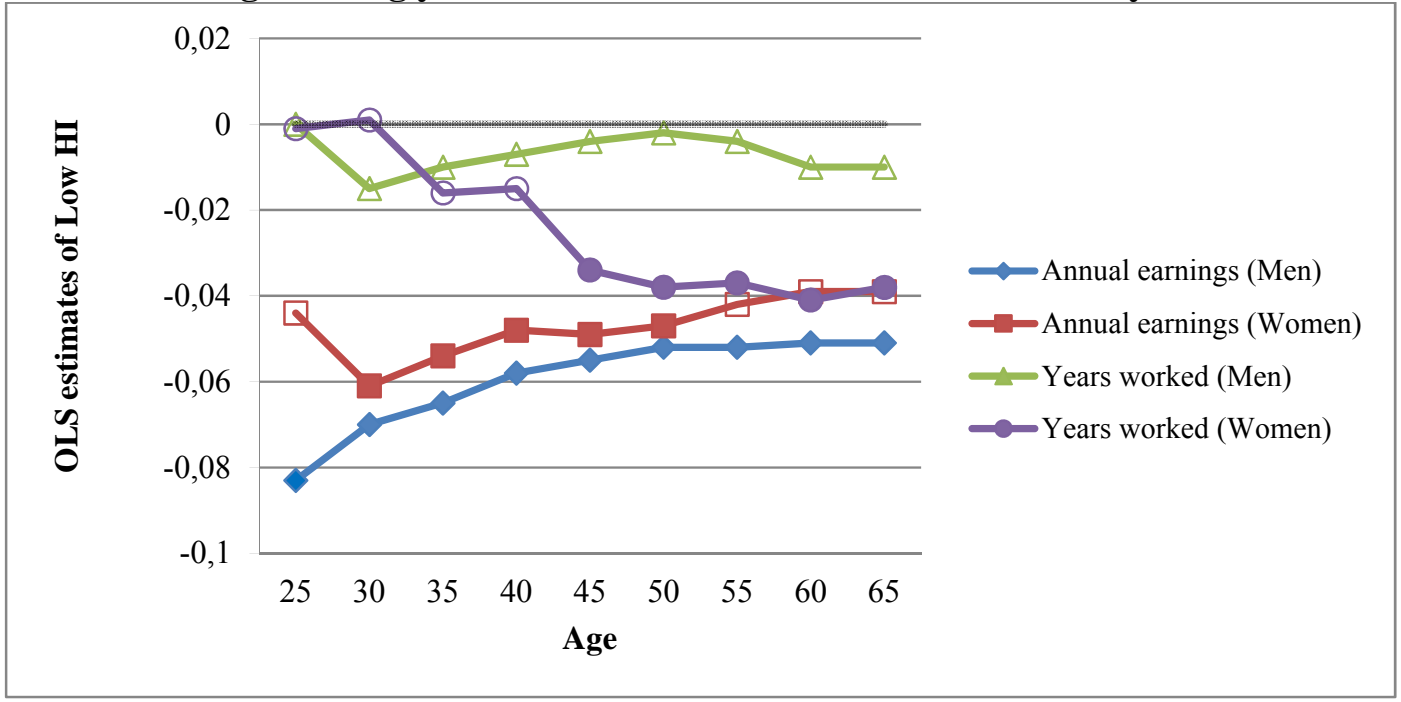

a The figure shows OLS estimates for Low childhood HI obtained from estimating linear models on the logarithm of (average) annual earnings and the logarithm of (accumulated) years worked at different ages over an individual's working life. The reference category is High childhood HI. All models include country dummies and birth-year dummies. A solid square, diamond, triangle or dot indicates significance at a $5 \%$ level based on robust standard errors. 
Figure 5. Marginal effects on the number of gaps over men and women's life cycle ${ }^{\mathrm{a}}$

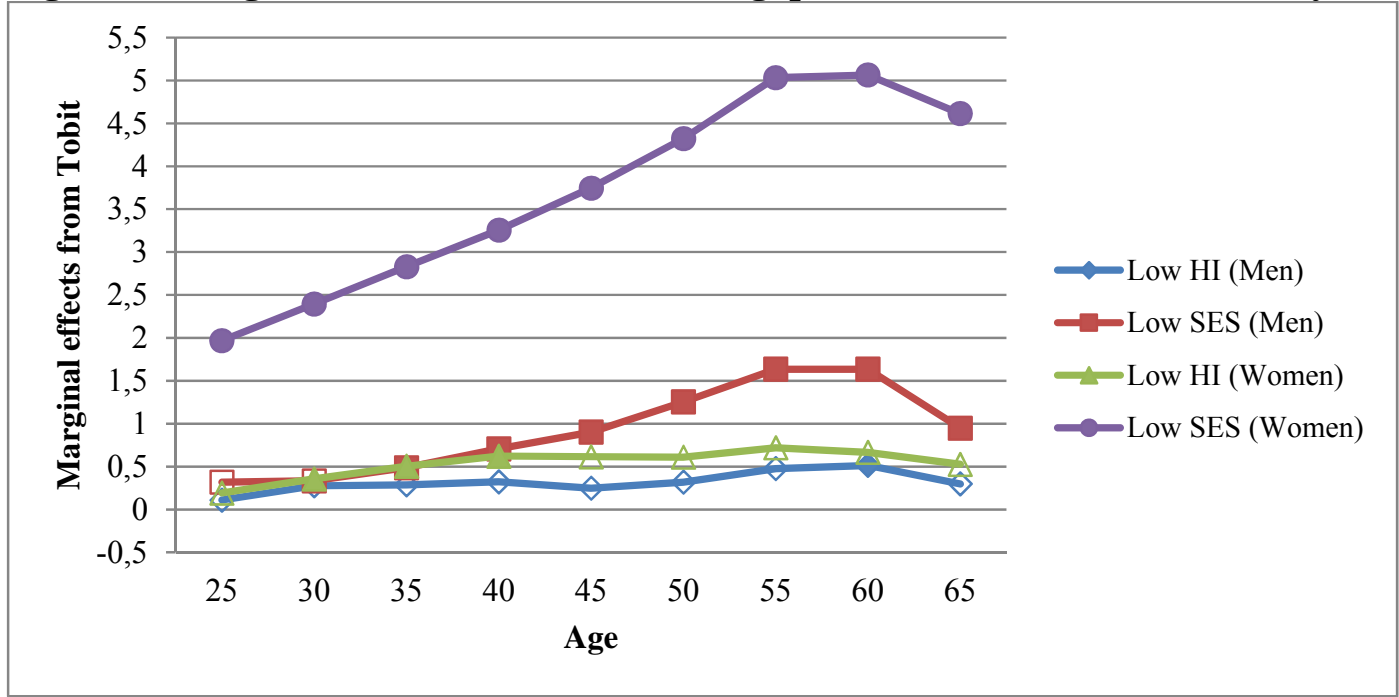

a The figure shows marginal effects (conditional on being uncensored) for Low childhood HI and Low childhood SES based on the estimation of Tobit models on the (accumulated) number of employment gaps at different ages over an individual's working life. The reference categories are, respectively, High childhood HI and High childhood SES. All models include country dummies and birth-year dummies. A solid square, diamond, triangle or dot indicates significance at a 5\% level based on robust standard errors.

\section{Figure 6. Estimates on the probability of leaving the labor market over men and women's life cycle ${ }^{\mathrm{a}}$}

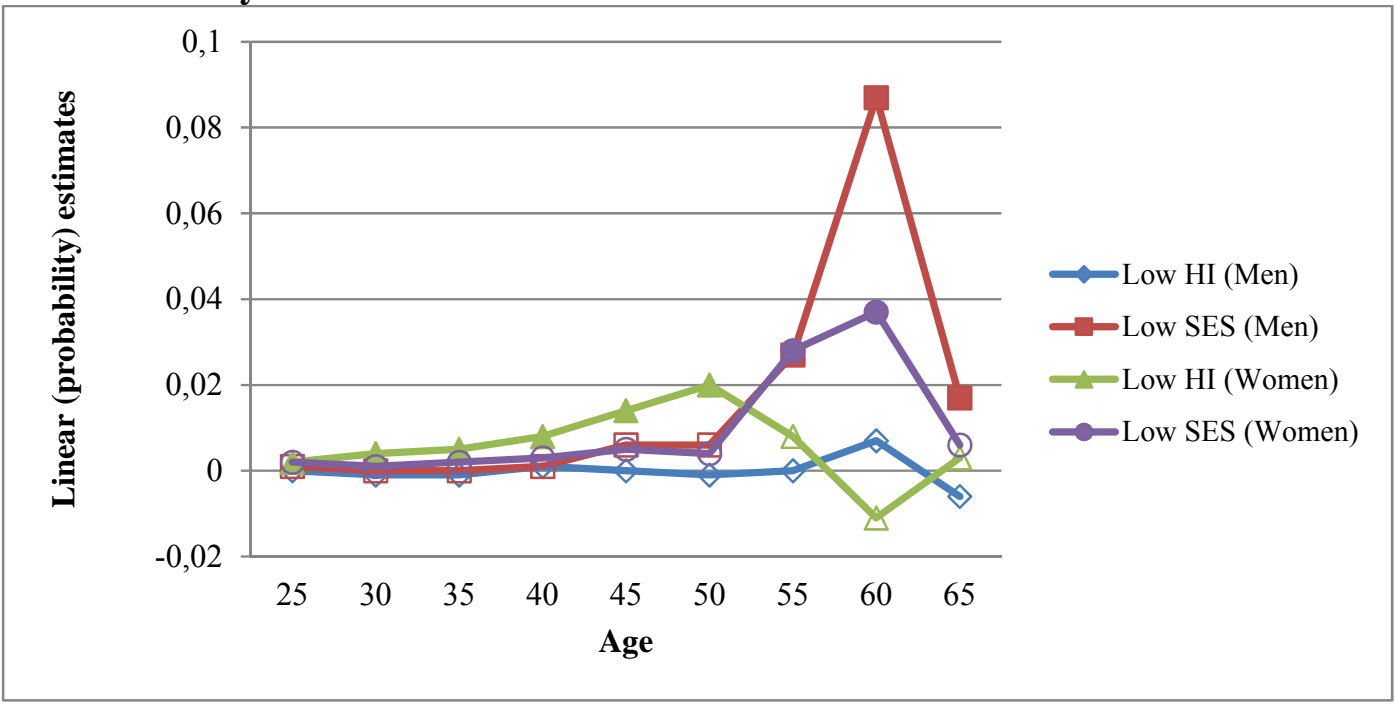

a The figure shows OLS estimates for Low childhood HI and Low childhood SES obtained from estimating linear models on the probability of leaving the labor market at different ages over an individual's working life. The reference categories are, respectively, High childhood HI and High childhood SES. All models include country dummies and birth-year dummies. A solid square, diamond, triangle or dot indicates significance at a $5 \%$ level based on robust standard errors. 
Figure 7. Estimates from log lifetime earnings regressions over men and women's life cycle in Nordic, Continental, Mediterranean and Transitional countries ${ }^{\mathrm{a}}$

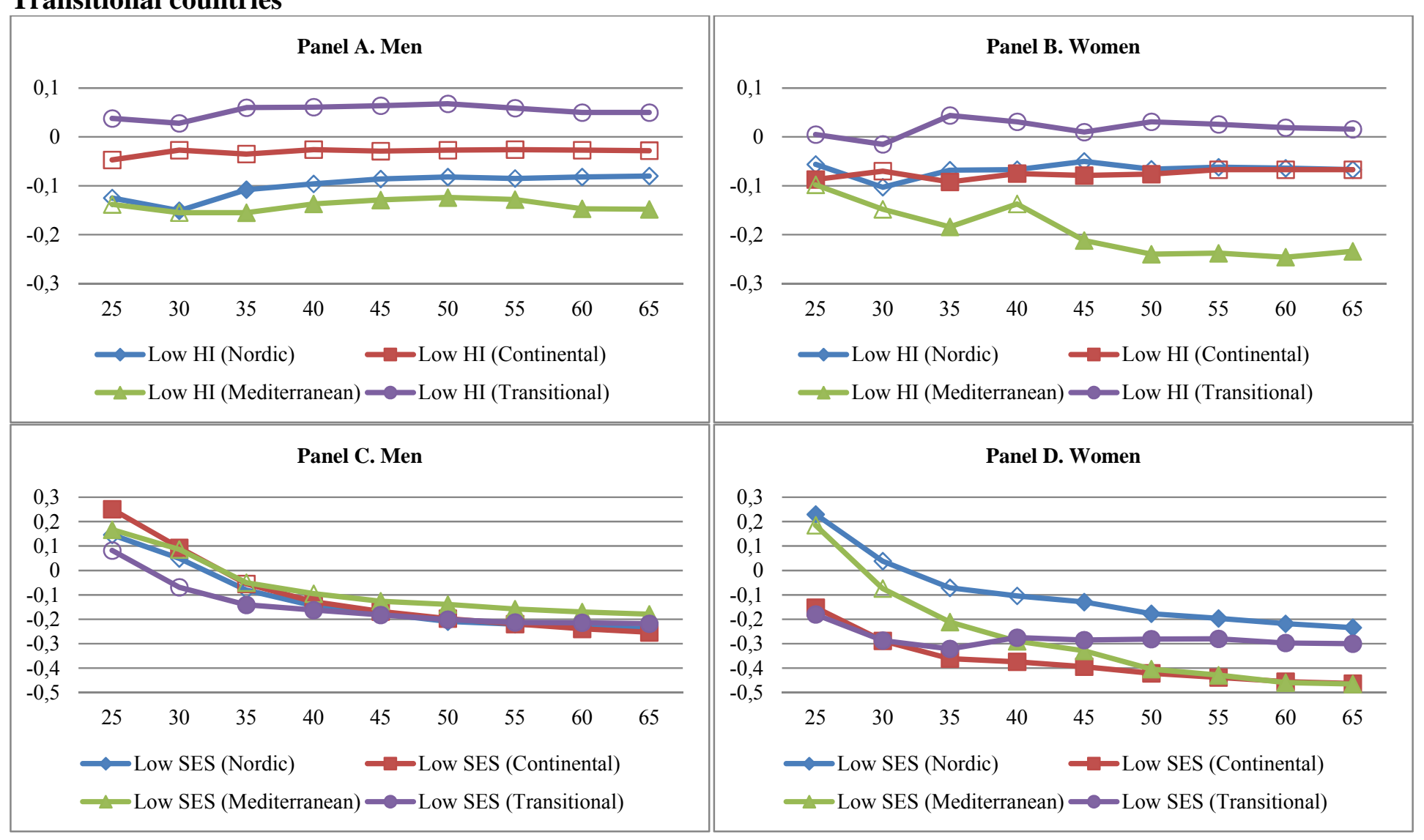

${ }^{a}$ The figure shows OLS estimates for Low childhood HI and Low childhood SES obtained from estimating linear models on the logarithm of accumulated earnings at different ages over an individual's working life by country-groups and for men and women. The reference categories are, respectively, High childhood HI and High childhood SES. All models include country dummies and birth-year dummies. A solid square, diamond, triangle or dot indicates significance at a 5\% level based on robust standard errors. 
Figure 8. Estimates from log average annual earnings regressions over men and women's life cycle in Nordic, Continental,

\section{Mediterranean and Transitional countries ${ }^{\mathrm{a}}$}

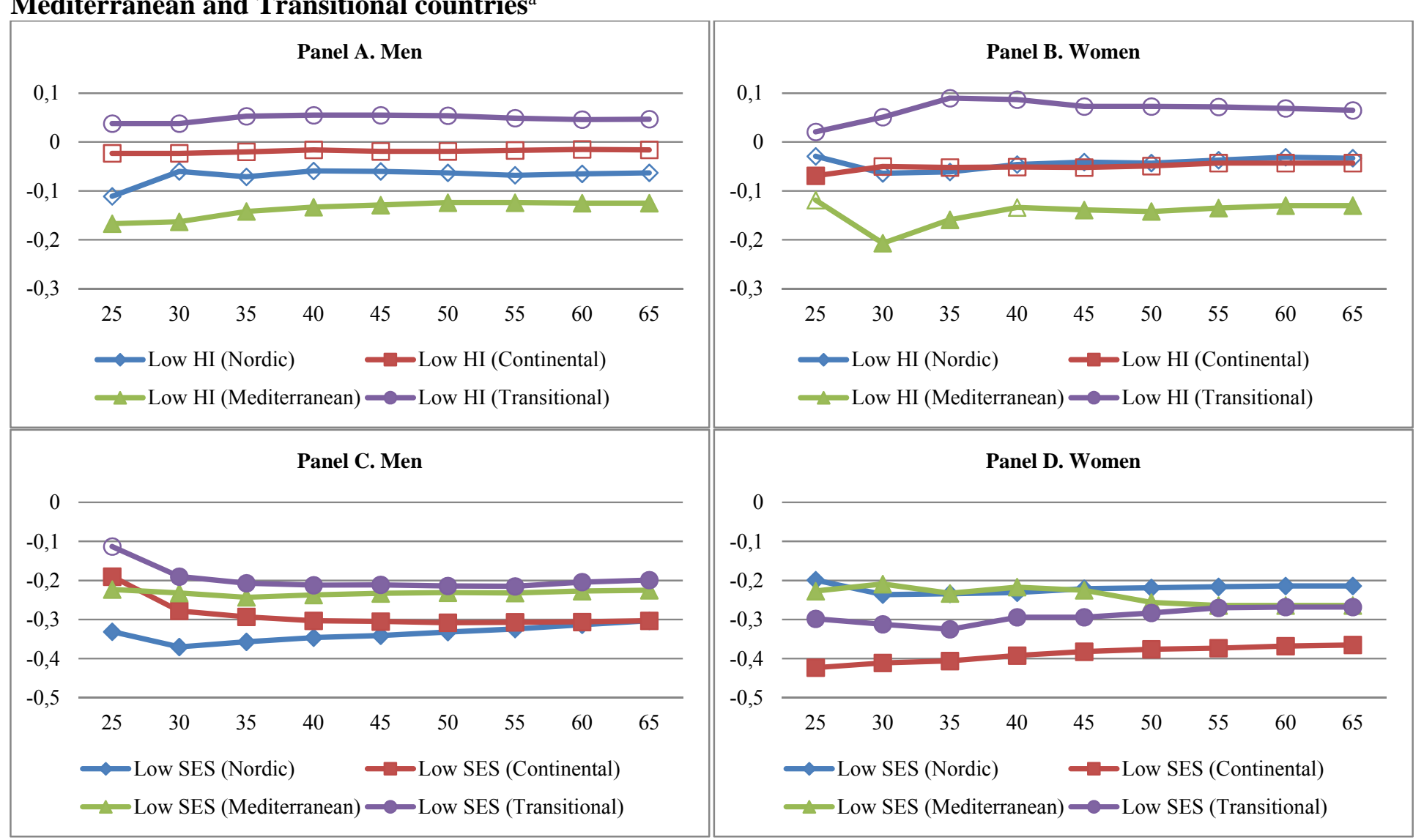

a The figure shows OLS estimates for Low childhood HI and Low childhood SES obtained from estimating linear models on the logarithm of (average) annual earnings at different ages over an individual's working life by country-groups and for men and women. The reference categories are, respectively, High childhood HI and High childhood SES. All models include country dummies and birth-year dummies. A solid square, diamond, triangle or dot indicates significance at a $5 \%$ level based on robust standard errors. 
Figure 9. Estimates from log working years regressions over men and women's life cycle in Nordic, Continental, Mediterranean and Transitional countries ${ }^{\mathrm{a}}$

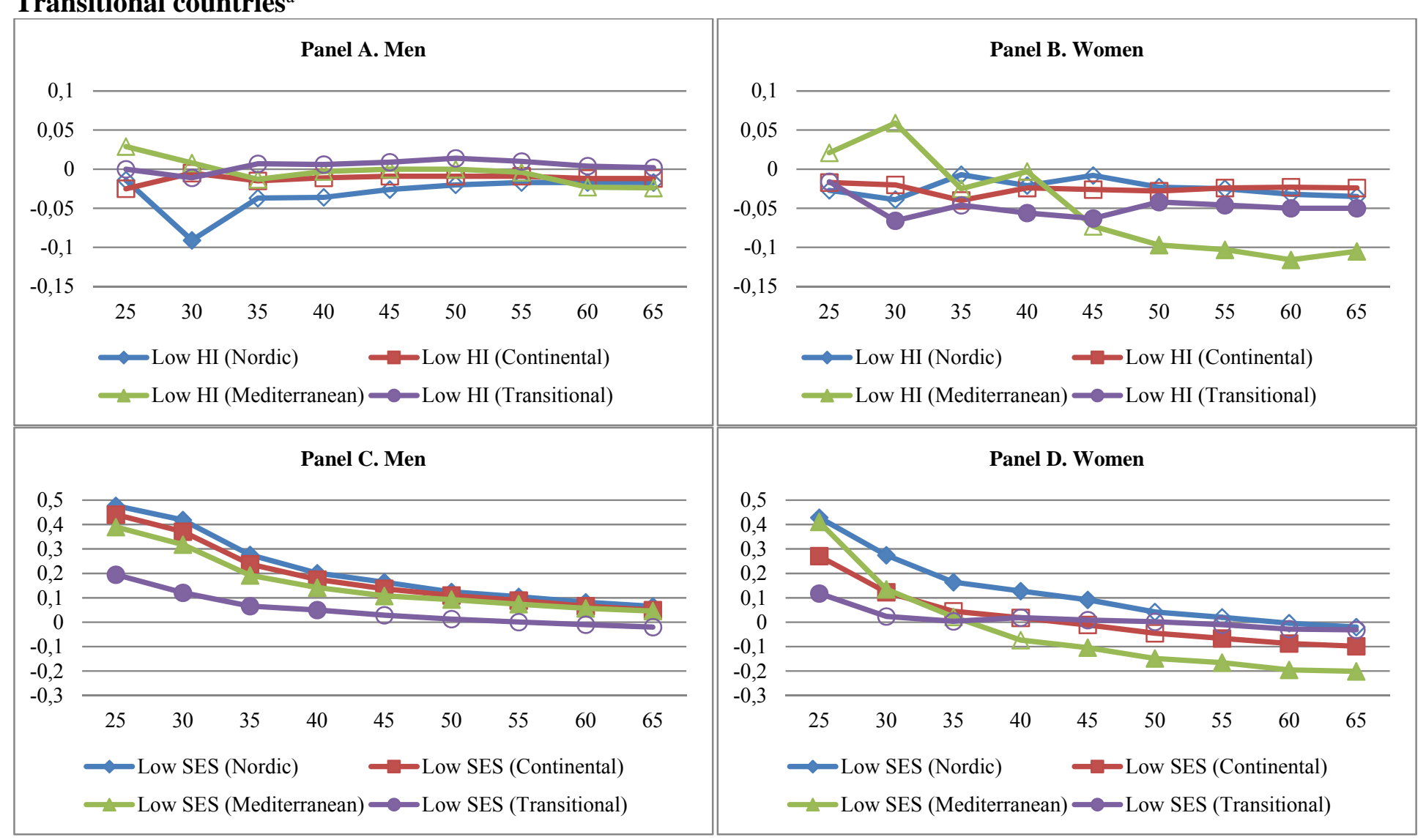

${ }^{a}$ The figure shows OLS estimates for Low childhood HI and Low childhood SES obtained from estimating linear models on the logarithm of (accumulated) working years at different ages over an individual's working life by country-groups and for men and women. The reference categories are, respectively, High childhood HI and High childhood SES. All models include country dummies and birth-year dummies. A solid square, diamond, triangle or dot indicates significance at a $5 \%$ level based on robust standard errors. 


\section{Table I Log lifetime earnings regressions for men and women in Europe ${ }^{a}$}

\begin{tabular}{|c|c|c|c|c|}
\hline & $\begin{array}{l}\text { Men } \\
(1)\end{array}$ & $(2)$ & $\begin{array}{l}\text { Women } \\
\text { (1) }\end{array}$ & $(2)$ \\
\hline Low childhood HI & $\begin{array}{l}-0.061 * * * \\
(0.020)\end{array}$ & & $\begin{array}{l}-0.076^{* * *} \\
(0.027)\end{array}$ & \\
\hline Medium childhood HI & $\begin{array}{l}-0.045 * * \\
(0.020)\end{array}$ & & $\begin{array}{l}-0.038 \\
(0.029)\end{array}$ & \\
\hline Low childhood SES & $\begin{array}{l}-0.241 * * * \\
(0.022)\end{array}$ & & $\begin{array}{l}-0.420 * * * \\
(0.030)\end{array}$ & \\
\hline Medium childhood SES & $\begin{array}{l}-0.106^{* * *} \\
(0.019)\end{array}$ & & $\begin{array}{l}-0.203^{* * *} \\
(0.025)\end{array}$ & \\
\hline Low HI * Low SES & & $\begin{array}{l}-0.309 * * * \\
(0.035)\end{array}$ & & $\begin{array}{l}-0.491 * * * \\
(0.048)\end{array}$ \\
\hline Low HI * Medium SES & & $\begin{array}{l}-0.181 * * * \\
(0.031)\end{array}$ & & $\begin{array}{l}-0.279 * * * \\
(0.042)\end{array}$ \\
\hline Low HI * High SES & & $\begin{array}{l}-0.096 * * * \\
(0.029)\end{array}$ & & $\begin{array}{l}0.001 \\
(0.040)\end{array}$ \\
\hline Medium HI * Low SES & & $\begin{array}{l}-0.310^{* * *} \\
(0.035)\end{array}$ & & $\begin{array}{l}-0.398 * * * \\
(0.054)\end{array}$ \\
\hline Medium HI * Medium SES & & $\begin{array}{l}-0.164 * * * \\
(0.033)\end{array}$ & & $\begin{array}{l}-0.194 * * * \\
(0.044)\end{array}$ \\
\hline Medium HI * High SES & & $\begin{array}{l}-0.065^{*} \\
(0.034)\end{array}$ & & $\begin{array}{l}-0.054 \\
(0.043)\end{array}$ \\
\hline High HI * Low SES & & $\begin{array}{l}-0.267 * * * \\
(0.035)\end{array}$ & & $\begin{array}{l}-0.382 * * * \\
(0.052)\end{array}$ \\
\hline High HI * Medium SES & & $\begin{array}{l}-0.135^{* * *} \\
(0.032)\end{array}$ & & $\begin{array}{l}-0.147 * * * \\
(0.048)\end{array}$ \\
\hline Buffering hypothesis ${ }^{b}$ & & 0.873 & & 0.049 \\
\hline R-squared & 0.247 & 0.247 & 0.180 & 0.181 \\
\hline Observations & 7803 & 7803 & 7170 & 7170 \\
\hline
\end{tabular}

a Based on the estimation of linear models on the logarithm of lifetime earnings using OLS. All models include both country dummies and birth-year dummies.

b The buffering hypothesis in Columns (2) shows the resulting p-value when testing $\beta_{\text {HighHI*LowSES }}$ $\beta_{\text {LowHI }}{ }_{\text {LowSES }}>\beta_{\text {HighHI*HighSES }}-\beta_{\text {LowHI }{ }^{*} \text { HighSES, where }} \beta_{\text {HighHI }}{ }_{\text {HighSES }}=0$. Robust standard errors in parentheses. Significance levels: $* * * \mathrm{p}<0.01 * * \mathrm{p}<0.05 * \mathrm{p}<0.10$. 
Table II Estimates for low childhood HI and low childhood SES from log lifetime earnings regressions for men and women in Europe (sensitivity analyses)

\begin{tabular}{|c|c|c|c|c|c|c|c|c|}
\hline & Men & & & & Women & & & \\
\hline & $\begin{array}{l}\text { Low HI } \\
\text { coefficient } \\
\text { (standard error) }\end{array}$ & $\begin{array}{l}\text { Low SES } \\
\text { coefficient } \\
\text { (standard error) }\end{array}$ & $\mathrm{R}^{2}$ & $\mathrm{~N}$ & $\begin{array}{l}\text { Low HI } \\
\text { coefficient } \\
\text { (standard error) }\end{array}$ & $\begin{array}{l}\text { Low SES } \\
\text { coefficient } \\
\text { (standard error) }\end{array}$ & $\mathrm{R}^{2}$ & $\mathrm{~N}$ \\
\hline 0 . Basic results from Table I & $\begin{array}{l}-0.061^{* * *} \\
(0.020)\end{array}$ & $\begin{array}{l}-0.241 * * * \\
(0.022)\end{array}$ & $\begin{array}{l}0.24 \\
7\end{array}$ & $\begin{array}{l}780 \\
3\end{array}$ & $\begin{array}{l}-0.076^{* * * *} \\
(0.027)\end{array}$ & $\begin{array}{l}-0.420^{* * *} \\
(0.030)\end{array}$ & $\begin{array}{l}0.18 \\
0\end{array}$ & $\begin{array}{l}717 \\
0\end{array}$ \\
\hline 1. Polychoric correlation matrix for PCA & $\begin{array}{c}-0.063 * * * \\
(0.020)\end{array}$ & $\begin{array}{c}-0.241 * * * \\
(0.022)\end{array}$ & $\begin{array}{l}0.24 \\
7\end{array}$ & $\begin{array}{l}780 \\
3\end{array}$ & $\begin{array}{c}-0.091 * * * \\
(0.028)\end{array}$ & $\begin{array}{c}-0.409 * * * \\
(0.030)\end{array}$ & $\begin{array}{l}0.17 \\
9\end{array}$ & $\begin{array}{l}717 \\
0\end{array}$ \\
\hline 2. Country-specific distributions for terciles & $\begin{array}{l}-0.053 * * * \\
(0.020)\end{array}$ & $\begin{array}{l}-0.223 * * * \\
(0.020)\end{array}$ & $\begin{array}{l}0.24 \\
7\end{array}$ & $\begin{array}{l}780 \\
3\end{array}$ & $\begin{array}{l}-0.081 * * * \\
(0.027)\end{array}$ & $\begin{array}{l}-0.365 * * * \\
(0.028)\end{array}$ & $\begin{array}{l}0.17 \\
8\end{array}$ & $\begin{array}{l}717 \\
0\end{array}$ \\
\hline 3. Excluding self-employed & $\begin{array}{c}-0.043 * * \\
(0.021)\end{array}$ & $\begin{array}{l}-0.246^{* * *} \\
(0.024)\end{array}$ & $\begin{array}{l}0.27 \\
3\end{array}$ & $\begin{array}{l}607 \\
0\end{array}$ & $\begin{array}{c}-0.070 * * \\
(0.029)\end{array}$ & $\begin{array}{l}-0.412 * * * \\
(0.032)\end{array}$ & $\begin{array}{l}0.18 \\
8\end{array}$ & $\begin{array}{l}624 \\
6\end{array}$ \\
\hline $\begin{array}{l}\text { 4. Without adjusting for part-time/full-time } \\
\text { work }\end{array}$ & $\begin{array}{l}-0.059 * * * \\
(0.019)\end{array}$ & $\begin{array}{l}-0.243 * * * \\
(0.022)\end{array}$ & $\begin{array}{l}0.25 \\
2\end{array}$ & $\begin{array}{l}780 \\
3\end{array}$ & $\begin{array}{l}-0.063 * * \\
(0.027)\end{array}$ & $\begin{array}{l}-0.404 * * * \\
(0.030)\end{array}$ & $\begin{array}{l}0.20 \\
3\end{array}$ & $\begin{array}{l}720 \\
7\end{array}$ \\
\hline 5. Assuming zero unemployment benefits & $\begin{array}{l}-0.062 * * * \\
(0.020)\end{array}$ & $\begin{array}{l}-0.243 * * * \\
(0.022)\end{array}$ & $\begin{array}{l}0.24 \\
6\end{array}$ & $\begin{array}{l}780 \\
2\end{array}$ & $\begin{array}{l}-0.072 * * * \\
(0.027)\end{array}$ & $\begin{array}{l}-0.433 * * * \\
(0.031)\end{array}$ & $\begin{array}{l}0.17 \\
9\end{array}$ & $\begin{array}{l}717 \\
1\end{array}$ \\
\hline 6. Excluding Greece and Poland & $\begin{array}{l}-0.066^{* * *} \\
(0.020)\end{array}$ & $\begin{array}{l}-0.243 * * * \\
(0.022)\end{array}$ & $\begin{array}{l}0.20 \\
8\end{array}$ & $\begin{array}{l}678 \\
5\end{array}$ & $\begin{array}{c}-0.068 * * \\
(0.028)\end{array}$ & $\begin{array}{l}-0.389 * * * \\
(0.030)\end{array}$ & $\begin{array}{l}0.16 \\
8\end{array}$ & $\begin{array}{l}638 \\
7\end{array}$ \\
\hline 7. Median regression & $\begin{array}{c}-0.037 * * \\
(0.018)\end{array}$ & $\begin{array}{c}-0.217 * * * \\
(0.021)\end{array}$ & - & $\begin{array}{l}780 \\
3\end{array}$ & $\begin{array}{c}-0.063 * * \\
(0.030)\end{array}$ & $\begin{array}{l}-0.408 * * * \\
(0.033)\end{array}$ & - & $\begin{array}{l}717 \\
0\end{array}$ \\
\hline 8. Controlling for height & $\begin{array}{l}-0.056^{* * *} \\
(0.019)\end{array}$ & $\begin{array}{l}-0.223 * * * \\
(0.022)\end{array}$ & $\begin{array}{l}0.25 \\
1\end{array}$ & $\begin{array}{l}773 \\
9\end{array}$ & $\begin{array}{c}-0.074 * * * \\
(0.027)\end{array}$ & $\begin{array}{c}-0.412 * * * \\
(0.031)\end{array}$ & $\begin{array}{l}0.17 \\
9\end{array}$ & $\begin{array}{l}712 \\
3\end{array}$ \\
\hline
\end{tabular}

${ }^{a}$ Based on the estimation of linear models on the logarithm of lifetime earnings using OLS, except in Row 7, where median regression is used. All models include both country dummies and birth-year dummies. Robust standard errors in parentheses, except for median regression in Row 7 . Significance levels: $* * *$ p $<0.01 * * \mathrm{p}<0.05 * \mathrm{p}<0.10$. 


\section{Appendix to "Early life circumstances and life cycle labor market outcomes"}

July 4, 2015

This appendix provides additional analyses and information to the main paper.

\section{A.1. Does our sample selection introduce a selectivity bias into our analysis?}

As described in more detail in Section 3, in our sample selection we exclude respondents who had never worked, who did not report any wage in SHARE (waves 1, 2 or 3 ) or for whom only one wage point is available, as well as a small number of individuals who worked for less than five years. We exclude these respondents for practical reasons (see also Alessie et al. 2013). However, because excluding all these individuals may introduce a selectivity bias into our analysis, we performed several robustness checks keeping these four groups in our sample, as shown in Table A.I. The table shows estimates for the bottom health and SES terciles obtained from estimating lifetime earnings regressions for men and women in Europe together with the number of observations (the full estimation results are available upon request). To facilitate comparison, we repeat our main estimation results from Table I in Row 0.

The first group of individuals, those who had never worked (i.e. also without lifetime earnings), are excluded because in order to investigate the implicit labor market behavior that may cause the associations between early life circumstances and lifetime earnings over the life cycle we need to estimate regressions on the logarithm of lifetime earnings, the logarithm of working years, and the logarithm of average annual earnings respectively. The reason for excluding respondents for whom only one wage point is available is that they would be assigned the same wage over their whole work career, because we use linear interpolation between respondents' wages to construct the wage 
profiles (see Section 3). Finally, the small number of individuals with less than five years of work experience are dropped to exclude individuals with very short employment histories. In a first robustness check, we replicated our main results in Columns (1) in Table 1 using our final sample but estimating the lifetime earnings regression in levels (Row 1 in Panel A). Next, we re-estimated the models keeping the three aforementioned groups of respondents (Row 2 in Panel A). Individuals who had never worked were assigned zero lifetime earnings (cf. Goodman et al. 2011). As shown, the estimates for the bottom childhood health and SES terciles remain virtually the same.

In the previous analysis, however, we still exclude respondents who despite working did not report any wage in SHARE (i.e. neither in SHARELIFE nor in waves 1 or 2). A more in-depth analysis of such respondents revealed that having been selfemployed at some point in their career had a positive effect on having worked over the life cycle but reporting no wage. In a final robustness check (Panel B), we estimated a Heckman selection model where the dependent variable, the logarithm of lifetime earnings, is missing if the individual had never worked or if despite working (s)he did not report any wage in SHARE. Having been self-employed during one's work career (self-employment spells) serves as an instrumental variable (IV) for having worked without reporting any wage, and the number of biological children is used as an IV for having never worked. As shown, the estimates of low childhood health and SES remain largely unchanged for men although not for women. Nevertheless, in the selection equation the estimate of self-employment spells is as expected (i.e. negative) for men only. The estimates of the other exclusion restrictions, the number of biological children, are positive for men and negative for women, as expected. 
In sum, when investigating this possible sample selection issue, our main results for childhood health and SES remain largely unchanged for men, although not for women, which is however what one would expect as the sample workforce composition changes more for the latter. 
Table A.I Additional sensitivity analyses

\begin{tabular}{|c|c|c|c|c|c|c|}
\hline Panel Aa & Men & & & Women & & \\
\hline & $\begin{array}{l}\text { Low HI coefficient } \\
\text { (standard error) }\end{array}$ & $\begin{array}{l}\text { Low SES coefficient } \\
\text { (standard error) }\end{array}$ & $\mathrm{N}$ & $\begin{array}{l}\text { Low HI coefficient } \\
\text { (standard error) }\end{array}$ & $\begin{array}{l}\text { Low SES coefficient } \\
\text { (standard error) }\end{array}$ & $\mathrm{N}$ \\
\hline 0. Regression in logs - final sample (see Columns (1) in Table 1) & $\begin{array}{l}-0.061 * * * \\
(0.020)\end{array}$ & $\begin{array}{l}-0.241 * * * \\
(0.022)\end{array}$ & 7,803 & $\begin{array}{l}-0.076^{* * *} \\
(0.027)\end{array}$ & $\begin{array}{l}-0.420 * * * \\
(0.030)\end{array}$ & 7,170 \\
\hline 1. Regression in levels - final sample & $\begin{array}{l}-113,282 * * \\
(50808)\end{array}$ & $\begin{array}{l}-273,889 * * * \\
(60650)\end{array}$ & 7,803 & $\begin{array}{l}-31,261 \\
(55792)\end{array}$ & $\begin{array}{l}-266,543 * * * \\
(52002)\end{array}$ & 7,170 \\
\hline 2. Regression in levels - extended sample & $\begin{array}{l}-109,699 * * * \\
(40776)\end{array}$ & $\begin{array}{l}-296,728 * * * \\
(45127)\end{array}$ & 9,196 & $\begin{array}{l}-970 \\
(27824)\end{array}$ & $\begin{array}{l}-208,787 * * * \\
(32548)\end{array}$ & 10,724 \\
\hline Panel B $^{b}$ & & & & & & \\
\hline & $\begin{array}{l}\text { Log lifetime earnings } \\
\text { equation }\end{array}$ & Selection equation & $\mathrm{N}$ & $\begin{array}{l}\text { Log lifetime earnings } \\
\text { equation }\end{array}$ & Selection equation & $\mathrm{N}$ \\
\hline Low childhood HI & $\begin{array}{l}-0.054^{* *} \\
(0.024)\end{array}$ & $\begin{array}{l}-0.030 \\
(0.039)\end{array}$ & 10,229 & $\begin{array}{l}-0.206^{* * *} \\
(0.033)\end{array}$ & $\begin{array}{l}0.135 * * * \\
(0.036)\end{array}$ & 12,312 \\
\hline Low childhood SES & $\begin{array}{l}-0.249 * * * \\
(0.027)\end{array}$ & $\begin{array}{l}-0.152 * * * \\
(0.049)\end{array}$ & & $\begin{array}{l}-0.230 * * * \\
(0.052)\end{array}$ & $\begin{array}{l}-0.201 * * * \\
(0.035)\end{array}$ & \\
\hline One child $(0-1)$ & & $\begin{array}{l}0.169 * * \\
(0.075)\end{array}$ & & & $\begin{array}{l}-0.066 \\
(0.051)\end{array}$ & \\
\hline Two children $(0-1)$ & & $\begin{array}{l}0.236^{* * * *} \\
(0.056)\end{array}$ & & & $\begin{array}{l}-0.162 * * * \\
(0.048)\end{array}$ & \\
\hline Three or more children $(0-1)$ & & $\begin{array}{l}0.186^{* * * *} \\
(0.058)\end{array}$ & & & $\begin{array}{l}-0.314 * * * \\
(0.051)\end{array}$ & \\
\hline Self-employment spells $(0-1)$ & & $\begin{array}{l}-0.254 * * * \\
(0.049)\end{array}$ & & & $\begin{array}{l}0.231 * * * \\
(0.042)\end{array}$ & \\
\hline
\end{tabular}


Table A.II Annual lifetime earnings (undiscounted, in PPP-adjusted German euros of 2006) ${ }^{\mathrm{a}}$

\begin{tabular}{lrrrrrr}
\hline & \multicolumn{7}{c}{ Men } & \multicolumn{5}{c}{ Women } \\
\hline & Medians & Means & $\mathrm{N}$ & Medians & Means & $\mathrm{N}$ \\
\hline Austria & 16,069 & 18,343 & 187 & 9,565 & 11,346 & 198 \\
Germany & 18,981 & 21,779 & 633 & 10,555 & 11,782 & 626 \\
Sweden & 17,505 & 22,657 & 628 & 11,418 & 14,341 & 723 \\
Netherlands & 16,899 & 18,905 & 758 & 7,643 & 9,657 & 684 \\
Spain & 14,092 & 22,272 & 496 & 8,409 & 15,142 & 316 \\
Italy & 12,817 & 15,967 & 878 & 9,636 & 12,099 & 621 \\
France & 20,416 & 35,059 & 614 & 12,879 & 26,752 & 576 \\
Denmark & 17,396 & 19,640 & 740 & 11,082 & 13,180 & 746 \\
Greece & 17,141 & 26,731 & 536 & 12,939 & 19,425 & 309 \\
Switzerland & 35,111 & 41,264 & 438 & 17,203 & 19,854 & 459 \\
Belgium & 19,719 & 21,740 & 856 & 13,824 & 14,872 & 666 \\
Czech Republic & 8,461 & 9,708 & 557 & 6,570 & 7,307 & 772 \\
Poland & 6,734 & 15,619 & 482 & 4,835 & 15,582 & 474 \\
\hline
\end{tabular}

${ }^{a}$ The table shows sample median and mean values for annualized earnings from employment obtained from SHARE (waves 1, 2 and 3), as well as sample sizes (N) by country and gender. All amounts are undiscounted and in PPP-adjusted German euros of 2006.

Table A.III Official age of retirement ${ }^{\mathrm{a}}$

\begin{tabular}{lcc}
\hline & Men & Women \\
\hline Sweden & 65 & 65 \\
Denmark & 65 & 65 \\
Switzerland & 65 & 64 \\
Netherlands & 65 & 65 \\
Germany & 65 & 65 \\
Belgium & 65 & 65 \\
France & 60 & 60 \\
Austria & 65 & 60 \\
Spain & 65 & 65 \\
Italy & 65 & 60 \\
Greece & 65 & 60 \\
Czech Republic & 62.2 & 59.3 \\
Poland & 65 & 60
\end{tabular}

Source: OECD Pensions at a Glance (www.oecd.org/els/social/pensions/PAG). ${ }^{\text {a }}$ The official age of retirement is shown for 2010 and corresponds to the age at which a pension can be received irrespective of whether a worker has a long insurance record of years of contributions. 
Table A.IV Childhood SES index

\begin{tabular}{|c|c|}
\hline & Pooled sample \\
\hline \multirow[t]{2}{*}{ Rooms per person in the household when 10 years old } & $0.434 * * *$ \\
\hline & $(0.00735)$ \\
\hline \multirow[t]{2}{*}{ Number of books at home when 10 years old } & $0.569 * * *$ \\
\hline & $(0.00460)$ \\
\hline Main breadwinner's occupation when 10 (in ISCO-88 skill levels) & $0.432 * * *$ \\
\hline Number of facilities in the household when 10 years old (range $0-5$ ) & $\begin{array}{l}(0.00742) \\
0.548 * * * \\
(0.00511)\end{array}$ \\
\hline Explained variance & 0.505 \\
\hline $\mathrm{N}$ & 14973 \\
\hline
\end{tabular}

\section{Table A.V Childhood health index (HI)}

\begin{tabular}{ll}
\hline & Pooled sample \\
\hline Childhood SRH (1 = excellent, 4 = fair, poor or changing) & $0.609^{* * *}$ \\
& $(0.0111)$ \\
Number of respiratory problems & $0.422^{* * *}$ \\
& $(0.0172)$ \\
Number of infectious diseases & $0.263^{* * *}$ \\
Number of cardiovascular diseases & $(0.0213)$ \\
& $0.211^{* * *}$ \\
Number of neurological and psychiatric diseases & $(0.0220)$ \\
& $0.365^{* * *}$ \\
Number of disorders of the sense organs & $(0.0190)$ \\
& $0.346^{* * *}$ \\
Number of neoplastic diseases and other serious health condition & $(0.0190)$ \\
& $0.290^{* * *}$ \\
Explained variance & $(0.0221)$ \\
$\mathrm{N}$ & 0.203 \\
\hline
\end{tabular}

a The table shows the factor loadings on the first principal component with its explained variance. Standard errors are in parentheses. Significance levels: $* * * p<0.01 * * \mathrm{p}<0.05 * \mathrm{p}<0.10$. 
Table A.VI Log lifetime earnings regressions over the life cycle for men and women in Europe (I) ${ }^{\mathrm{a}}$

\begin{tabular}{|c|c|c|c|c|c|c|c|c|c|}
\hline Men & $\begin{array}{l}\text { Until age } 25 \\
\text { (1) }\end{array}$ & $\begin{array}{l}\text { Until age } 30 \\
(2)\end{array}$ & $\begin{array}{l}\text { Until age } 35 \\
\text { (3) }\end{array}$ & $\begin{array}{l}\text { Until age } 40 \\
\text { (4) }\end{array}$ & $\begin{array}{l}\text { Until age } 45 \\
\text { (5) }\end{array}$ & $\begin{array}{l}\text { Until age } 50 \\
(6)\end{array}$ & $\begin{array}{l}\text { Until age } 55 \\
\text { (7) }\end{array}$ & $\begin{array}{l}\text { Until age } 60 \\
(8)\end{array}$ & $\begin{array}{l}\text { Until age } 65 \\
\text { (9) }\end{array}$ \\
\hline \multirow[t]{2}{*}{ Low childhood HI } & $-0.084 * * *$ & $-0.085^{* * *}$ & $-0.075 * * *$ & $-0.064 * * *$ & $-0.059 * * *$ & $-0.055 * * *$ & $-0.056 * * *$ & $-0.061 * * *$ & $-0.061 * * *$ \\
\hline & $(0.030)$ & $(0.025)$ & $(0.022)$ & $(0.021)$ & $(0.021)$ & $(0.020)$ & $(0.020)$ & $(0.020)$ & $(0.020)$ \\
\hline \multirow[t]{2}{*}{ Medium childhood HI } & $-0.085 * * *$ & $-0.091 * * *$ & $-0.078 * * *$ & $-0.072 * * *$ & $-0.061 * * *$ & $-0.053 * *$ & $-0.050 * *$ & $-0.046 * *$ & $-0.045 * *$ \\
\hline & $(0.032)$ & $(0.027)$ & $(0.024)$ & $(0.023)$ & $(0.022)$ & $(0.021)$ & $(0.021)$ & $(0.021)$ & $(0.021)$ \\
\hline \multirow[t]{2}{*}{ Low childhood SES } & $0.230 * * *$ & $0.089 * * *$ & $-0.056 * *$ & $-0.124 * * *$ & $-0.162 * * *$ & $-0.189 * * *$ & $-0.210 * * *$ & $-0.225 * * *$ & $-0.239 * * *$ \\
\hline & $(0.034)$ & $(0.029)$ & $(0.025)$ & $(0.024)$ & $(0.023)$ & $(0.023)$ & $(0.022)$ & $(0.022)$ & $(0.022)$ \\
\hline \multirow[t]{2}{*}{ Medium childhood SES } & $0.241 * * *$ & $0.132 * * *$ & 0.026 & -0.027 & $-0.053 * * *$ & $-0.073 * * *$ & $-0.082 * * *$ & $-0.098 * * *$ & $-0.106 * * *$ \\
\hline & $(0.031)$ & $(0.025)$ & $(0.021)$ & $(0.021)$ & $(0.020)$ & $(0.020)$ & $(0.019)$ & $(0.019)$ & $(0.019)$ \\
\hline R-squared & 0.144 & 0.161 & 0.192 & 0.202 & 0.213 & 0.220 & 0.231 & 0.238 & 0.247 \\
\hline Observations & 7060 & 7693 & 7772 & 7793 & 7798 & 7800 & 7800 & 7803 & 7803 \\
\hline Women & $(1)$ & $(2)$ & (3) & $(4)$ & $(5)$ & $(6)$ & $(7)$ & $(8)$ & $(9)$ \\
\hline \multirow[t]{2}{*}{ Low childhood HI } & -0.045 & $-0.060 * *$ & $-0.070 * *$ & $-0.063 * *$ & $-0.084 * * *$ & $-0.085 * * *$ & $-0.079 * * *$ & $-0.080 * * *$ & $-0.077 * * *$ \\
\hline & $(0.031)$ & $(0.029)$ & $(0.028)$ & $(0.028)$ & $(0.028)$ & $(0.028)$ & $(0.027)$ & $(0.027)$ & $(0.027)$ \\
\hline \multirow[t]{2}{*}{ Medium childhood HI } & 0.003 & -0.034 & -0.033 & -0.035 & $-0.054^{*}$ & -0.046 & -0.045 & -0.042 & -0.040 \\
\hline & $(0.033)$ & $(0.031)$ & $(0.029)$ & $(0.030)$ & $(0.030)$ & $(0.029)$ & $(0.029)$ & $(0.029)$ & $(0.029)$ \\
\hline \multirow[t]{2}{*}{ Low childhood SES } & -0.014 & $-0.192 * * *$ & $-0.286 * * *$ & $-0.314 * * *$ & $-0.332 * * *$ & $-0.371 * * *$ & $-0.392 * * *$ & $-0.411 * * *$ & $-0.421 * * *$ \\
\hline & $(0.033)$ & $(0.032)$ & $(0.031)$ & $(0.032)$ & $(0.031)$ & $(0.031)$ & $(0.031)$ & $(0.030)$ & $(0.030)$ \\
\hline Medium childhood SES & $(0.029)$ & $(0.027)$ & $(0.026)$ & $(0.026)$ & $(0.026)$ & $(0.026)$ & $(0.025)$ & $(0.025)$ & $(0.025)$ \\
\hline R-squared & 0.159 & 0.159 & 0.163 & 0.157 & 0.153 & 0.156 & 0.161 & 0.173 & 0.181 \\
\hline Observations & 6505 & 6849 & 6972 & 7063 & 7128 & 7160 & 7167 & 7169 & 7170 \\
\hline
\end{tabular}

${ }^{a}$ Based on the estimation of linear models on the logarithm of accumulated earnings at different ages over an individual's working life using OLS. All models include country dummies and birth-year dummies. Robust standard errors in parentheses. Significance levels: $* * * \mathrm{p}<0.01 * * \mathrm{p}<0.05 * \mathrm{p}<0.10$. 
Table A.VII Log lifetime earnings regressions over the life cycle for men and women in Europe (II) ${ }^{\mathrm{a}}$

\begin{tabular}{|c|c|c|c|c|c|c|c|c|c|}
\hline Men & Until age 25 & Until age 30 & Until age 35 & Until age 40 & Until age 45 & Until age 50 & Until age 55 & Until age 60 & Until age 65 \\
\hline \multirow[t]{2}{*}{ Low HI * Low SES } & $0.165 * * *$ & 0.024 & $-0.120 * * *$ & $-0.181 * * *$ & $-0.216^{* * *}$ & $-0.243 * * *$ & $-0.269 * * *$ & $-0.292 * * *$ & $-0.308 * * *$ \\
\hline & $(0.055)$ & $(0.047)$ & $(0.040)$ & $(0.038)$ & $(0.037)$ & $(0.037)$ & $(0.036)$ & $(0.036)$ & $(0.035)$ \\
\hline \multirow[t]{2}{*}{ Low HI * Medium SES } & $0.147 * * *$ & 0.043 & $-0.070 * *$ & $-0.114 * * *$ & $-0.134 * * *$ & $-0.149 * * *$ & $-0.158 * * *$ & $-0.177 * * *$ & $-0.182 * * *$ \\
\hline & $(0.051)$ & $(0.042)$ & $(0.035)$ & $(0.033)$ & $(0.033)$ & $(0.032)$ & $(0.031)$ & $(0.031)$ & $(0.031)$ \\
\hline \multirow[t]{2}{*}{ Low HI * High SES } & $-0.124 * *$ & $-0.101 * *$ & $-0.100 * * *$ & $-0.100 * * *$ & $-0.096^{* * *}$ & $-0.097 * * *$ & $-0.098 * * *$ & $-0.098^{* * *}$ & $-0.097 * * *$ \\
\hline & $(0.052)$ & $(0.041)$ & $(0.033)$ & $(0.032)$ & $(0.031)$ & $(0.031)$ & $(0.030)$ & $(0.030)$ & $(0.029)$ \\
\hline \multirow[t]{2}{*}{ Medium HI * Low SES } & $0.109 *$ & -0.018 & $-0.158 * * *$ & $-0.225 * * *$ & $-0.252 * * *$ & $-0.274 * * *$ & $-0.290 * * *$ & $-0.298 * * *$ & $-0.308 * * *$ \\
\hline & $(0.058)$ & $(0.049)$ & $(0.042)$ & $(0.040)$ & $(0.038)$ & $(0.037)$ & $(0.036)$ & $(0.036)$ & $(0.035)$ \\
\hline \multirow[t]{2}{*}{ Medium HI * Medium SES } & $0.149 * * *$ & 0.036 & -0.056 & $-0.109 * * *$ & $-0.126^{* * *}$ & $-0.140 * * *$ & $-0.148 * * *$ & $-0.156^{* * *}$ & $-0.164 * * *$ \\
\hline & $(0.054)$ & $(0.046)$ & $(0.038)$ & $(0.036)$ & $(0.035)$ & $(0.035)$ & $(0.034)$ & $(0.033)$ & $(0.033)$ \\
\hline \multirow[t]{2}{*}{ Medium HI * High SES } & -0.063 & -0.070 & $-0.088^{* *}$ & $-0.084 * *$ & $-0.077 * *$ & $-0.070 * *$ & $-0.072 * *$ & $-0.069 * *$ & $-0.068 * *$ \\
\hline & $(0.059)$ & $(0.047)$ & $(0.039)$ & $(0.037)$ & $(0.036)$ & $(0.035)$ & $(0.034)$ & $(0.034)$ & $(0.034)$ \\
\hline \multirow[t]{2}{*}{ High HI * Low SES } & $0.214 * * *$ & $0.081 *$ & $-0.079 * *$ & $-0.154 * * *$ & $-0.193 * * *$ & $-0.222 * * *$ & $-0.243 * * *$ & $-0.255 * * *$ & $-0.267 * * *$ \\
\hline & $(0.055)$ & $(0.047)$ & $(0.040)$ & $(0.038)$ & $(0.037)$ & $(0.036)$ & $(0.036)$ & $(0.035)$ & $(0.035)$ \\
\hline \multirow[t]{2}{*}{ High HI * Medium SES } & $0.228 * * *$ & $0.137 * * *$ & 0.015 & -0.047 & $-0.075 * *$ & $-0.102 * * *$ & $-0.114 * * *$ & $-0.129 * * *$ & $-0.136^{* * *}$ \\
\hline & $(0.052)$ & $(0.044)$ & $(0.037)$ & $(0.035)$ & $(0.034)$ & $(0.034)$ & $(0.033)$ & $(0.032)$ & $(0.032)$ \\
\hline Buffering hypothesis ${ }^{b}$ & 0.845 & 0.756 & 0.868 & 0.923 & 0.928 & 0.938 & 0.934 & 0.899 & 0.881 \\
\hline R-squared & 0.145 & 0.161 & 0.193 & 0.202 & 0.214 & 0.220 & 0.232 & 0.238 & 0.247 \\
\hline
\end{tabular}


Table A.VII Continued

\begin{tabular}{|c|c|c|c|c|c|c|c|c|c|}
\hline Women & Until age 25 & Until age 30 & Until age 35 & Until age 40 & Until age 45 & Until age 50 & Until age 55 & Until age 60 & Until age 65 \\
\hline Low HI * Low SES & $\begin{array}{l}-0.053 \\
(0.053)\end{array}$ & $\begin{array}{l}-0.256^{* * *} \\
(0.049)\end{array}$ & $\begin{array}{l}-0.357 * * * \\
(0.049)\end{array}$ & $\begin{array}{l}-0.378^{* * *} \\
(0.051)\end{array}$ & $\begin{array}{l}-0.415^{* * *} \\
(0.048)\end{array}$ & $\begin{array}{l}-0.451^{* * * *} \\
(0.048)\end{array}$ & $\begin{array}{l}-0.469 * * * \\
(0.048)\end{array}$ & $\begin{array}{l}-0.485^{* * *} \\
(0.048)\end{array}$ & $\begin{array}{l}-0.492^{* * * *} \\
(0.048)\end{array}$ \\
\hline Low HI * Medium SES & $\begin{array}{l}0.018 \\
(0.049)\end{array}$ & $\begin{array}{l}-0.142 * * * \\
(0.045)\end{array}$ & $\begin{array}{l}-0.204 * * * \\
(0.043)\end{array}$ & $\begin{array}{l}-0.226^{* * * *} \\
(0.045)\end{array}$ & $\begin{array}{l}-0.247 * * * \\
(0.043)\end{array}$ & $\begin{array}{l}-0.266^{* * * *} \\
(0.043)\end{array}$ & $\begin{array}{l}-0.268^{* * *} \\
(0.042)\end{array}$ & $\begin{array}{l}-0.272 * * * \\
(0.042)\end{array}$ & $\begin{array}{l}-0.279 * * * \\
(0.042)\end{array}$ \\
\hline Low HI * High SES & $\begin{array}{l}0.020 \\
(0.050)\end{array}$ & $\begin{array}{l}-0.036 \\
(0.045)\end{array}$ & $\begin{array}{l}-0.022 \\
(0.043)\end{array}$ & $\begin{array}{l}-0.009 \\
(0.044)\end{array}$ & $\begin{array}{l}-0.027 \\
(0.042)\end{array}$ & $\begin{array}{l}-0.018 \\
(0.041)\end{array}$ & $\begin{array}{l}-0.008 \\
(0.040)\end{array}$ & $\begin{array}{l}-0.001 \\
(0.040)\end{array}$ & $\begin{array}{l}-0.000 \\
(0.040)\end{array}$ \\
\hline Medium HI * Low SES & $\begin{array}{l}0.055 \\
(0.059)\end{array}$ & $\begin{array}{l}-0.195^{* * * *} \\
(0.056)\end{array}$ & $\begin{array}{l}-0.268^{* * *} \\
(0.054)\end{array}$ & $\begin{array}{l}-0.298^{* * *} \\
(0.057)\end{array}$ & $\begin{array}{l}-0.333^{* * *} \\
(0.055)\end{array}$ & $\begin{array}{l}-0.356^{* * * *} \\
(0.055)\end{array}$ & $\begin{array}{l}-0.371^{* * *} \\
(0.054)\end{array}$ & $\begin{array}{l}-0.388^{* * *} \\
(0.054)\end{array}$ & $\begin{array}{l}-0.400 * * * \\
(0.054)\end{array}$ \\
\hline Medium HI * Medium SES & $\begin{array}{l}0.083 \\
(0.052)\end{array}$ & $\begin{array}{l}-0.070 \\
(0.047)\end{array}$ & $\begin{array}{l}-0.126^{* * *} \\
(0.046)\end{array}$ & $\begin{array}{l}-0.149 * * * \\
(0.047)\end{array}$ & $\begin{array}{l}-0.175^{* * *} \\
(0.045)\end{array}$ & $\begin{array}{l}-0.182 * * * \\
(0.045)\end{array}$ & $\begin{array}{l}-0.186^{* * *} \\
(0.044)\end{array}$ & $\begin{array}{l}-0.188^{* * *} \\
(0.044)\end{array}$ & $\begin{array}{l}-0.193 * * * \\
(0.044)\end{array}$ \\
\hline Medium HI * High SES & $\begin{array}{l}0.003 \\
(0.056)\end{array}$ & $\begin{array}{l}-0.086^{*} \\
(0.050)\end{array}$ & $\begin{array}{l}-0.070 \\
(0.046)\end{array}$ & $\begin{array}{l}-0.073 \\
(0.047)\end{array}$ & $\begin{array}{l}-0.082^{*} \\
(0.046)\end{array}$ & $\begin{array}{l}-0.072 \\
(0.044)\end{array}$ & $\begin{array}{l}-0.072 \\
(0.044)\end{array}$ & $\begin{array}{l}-0.057 \\
(0.043)\end{array}$ & $\begin{array}{l}-0.055 \\
(0.043)\end{array}$ \\
\hline High HI * Low SES & $\begin{array}{l}0.015 \\
(0.060)\end{array}$ & $\begin{array}{l}-0.226^{* * * *} \\
(0.056)\end{array}$ & $\begin{array}{l}-0.289 * * * \\
(0.054)\end{array}$ & $\begin{array}{l}-0.312 * * * \\
(0.056)\end{array}$ & $\begin{array}{l}-0.320^{* * * *} \\
(0.053)\end{array}$ & $\begin{array}{l}-0.354 * * * \\
(0.053)\end{array}$ & $\begin{array}{l}-0.368^{* * * *} \\
(0.052)\end{array}$ & $\begin{array}{l}-0.371 * * * \\
(0.052)\end{array}$ & $\begin{array}{l}-0.381 * * * \\
(0.052)\end{array}$ \\
\hline High HI * Medium SES & $\begin{array}{l}0.113^{* *} \\
(0.056)\end{array}$ & $\begin{array}{l}-0.028 \\
(0.052)\end{array}$ & $\begin{array}{l}-0.079 \\
(0.050)\end{array}$ & $\begin{array}{l}-0.105^{* *} \\
(0.051)\end{array}$ & $\begin{array}{l}-0.109 * * \\
(0.050)\end{array}$ & $\begin{array}{l}-0.118 * * \\
(0.049)\end{array}$ & $\begin{array}{l}-0.128^{* * * *} \\
(0.048)\end{array}$ & $\begin{array}{l}-0.136^{* * * *} \\
(0.048)\end{array}$ & $\begin{array}{l}-0.147 * * * \\
(0.048)\end{array}$ \\
\hline Buffering hypothesis ${ }^{b}$ & 0.123 & 0.531 & 0.251 & 0.207 & 0.158 & 0.121 & 0.080 & 0.043 & 0.047 \\
\hline R-squared & 0.160 & 0.160 & 0.163 & 0.158 & 0.154 & 0.157 & 0.162 & 0.174 & 0.182 \\
\hline Observations & 6505 & 6849 & 6972 & 7063 & 7128 & 7160 & 7167 & 7169 & 7170 \\
\hline
\end{tabular}

a Based on the estimation of linear models on the logarithm of accumulated earnings equations at different ages over an individual's working life using OLS. All models include country dummies and birth-year dummies.

${ }^{\mathrm{b}}$ The buffering hypothesis shows the resulting $\mathrm{p}$-value when testing $\beta_{\text {HighHI*LowSES }}-\beta_{\text {LowHI*LowSES }}>\beta_{\text {HighHI*HighSES }}-\beta_{\text {LowHI*HighSES, where }} \beta_{\text {HighHI*HighSES }}=0$. Robust standard errors in parentheses. Significance levels: $* * * \mathrm{p}<0.01 * * \mathrm{p}<0.05 * \mathrm{p}<0.10$. 
Table A.VIII Log annual earnings regressions over the life cycle for men and women in Europe ${ }^{\mathrm{a}}$

\begin{tabular}{|c|c|c|c|c|c|c|c|c|c|}
\hline Men & $\begin{array}{l}\text { Until age } 25 \\
\text { (1) }\end{array}$ & $\begin{array}{l}\text { Until age } 30 \\
\text { (2) }\end{array}$ & $\begin{array}{l}\text { Until age } 35 \\
\text { (3) }\end{array}$ & $\begin{array}{l}\text { Until age } 40 \\
\text { (4) }\end{array}$ & $\begin{array}{l}\text { Until age } 45 \\
\text { (5) }\end{array}$ & $\begin{array}{l}\text { Until age } 50 \\
(6)\end{array}$ & $\begin{array}{l}\text { Until age } 55 \\
\text { (7) }\end{array}$ & $\begin{array}{l}\text { Until age } 60 \\
(8)\end{array}$ & $\begin{array}{l}\text { Until age } 65 \\
\text { (9) }\end{array}$ \\
\hline Low childhood HI & $\begin{array}{l}-0.083^{* * *} \\
(0.026)\end{array}$ & $\begin{array}{l}-0.070 * * * \\
(0.023)\end{array}$ & $\begin{array}{l}-0.065^{* * *} \\
(0.021)\end{array}$ & $\begin{array}{l}-0.058^{* * *} \\
(0.021)\end{array}$ & $\begin{array}{l}-0.055^{* * *} \\
(0.020)\end{array}$ & $\begin{array}{l}-0.052 * * * \\
(0.020)\end{array}$ & $\begin{array}{l}-0.052^{* * *} \\
(0.020)\end{array}$ & $\begin{array}{l}-0.051 * * * \\
(0.019)\end{array}$ & $\begin{array}{l}-0.051 * * * \\
(0.019)\end{array}$ \\
\hline Medium childhood HI & $\begin{array}{l}-0.071 * * \\
(0.029)\end{array}$ & $\begin{array}{l}-0.061 * * \\
(0.025)\end{array}$ & $\begin{array}{l}-0.057 * * \\
(0.023)\end{array}$ & $\begin{array}{l}-0.056^{* *} \\
(0.022)\end{array}$ & $\begin{array}{l}-0.050 * * \\
(0.022)\end{array}$ & $\begin{array}{l}-0.048 * * \\
(0.021)\end{array}$ & $\begin{array}{l}-0.046^{* *} \\
(0.021)\end{array}$ & $\begin{array}{l}-0.043 * * \\
(0.020)\end{array}$ & $\begin{array}{l}-0.042 * * \\
(0.020)\end{array}$ \\
\hline Low childhood SES & $\begin{array}{l}-0.208^{* * * *} \\
(0.030)\end{array}$ & $\begin{array}{l}-0.265^{* * * *} \\
(0.026)\end{array}$ & $\begin{array}{l}-0.285^{* * * *} \\
(0.024)\end{array}$ & $\begin{array}{l}-0.290 * * * \\
(0.024)\end{array}$ & $\begin{array}{l}-0.290 * * * \\
(0.023)\end{array}$ & $\begin{array}{l}-0.291 * * * \\
(0.023)\end{array}$ & $\begin{array}{l}-0.290^{* * *} \\
(0.022)\end{array}$ & $\begin{array}{l}-0.286^{* * *} \\
(0.022)\end{array}$ & $\begin{array}{l}-0.284 * * * \\
(0.022)\end{array}$ \\
\hline Medium childhood SES & $\begin{array}{l}-0.053 * * \\
(0.026)\end{array}$ & $\begin{array}{l}-0.107 * * * \\
(0.023)\end{array}$ & $\begin{array}{l}-0.132 * * * \\
(0.021)\end{array}$ & $\begin{array}{l}-0.139 * * * \\
(0.020)\end{array}$ & $\begin{array}{l}-0.144 * * * \\
(0.020)\end{array}$ & $\begin{array}{l}-0.146^{* * *} \\
(0.020)\end{array}$ & $\begin{array}{l}-0.144^{* * *} \\
(0.019)\end{array}$ & $\begin{array}{l}-0.145^{* * *} \\
(0.019)\end{array}$ & $\begin{array}{l}-0.145^{* * *} \\
(0.019)\end{array}$ \\
\hline R-squared & 0.216 & 0.232 & 0.242 & 0.239 & 0.240 & 0.239 & 0.242 & 0.243 & 0.243 \\
\hline Observations & 7060 & 7693 & 7772 & 7793 & 7798 & 7800 & 7800 & 7803 & 7803 \\
\hline Women & (1) & $(2)$ & (3) & (4) & $(5)$ & $(6)$ & (7) & $(8)$ & (9) \\
\hline Low childhood HI & $\begin{array}{l}-0.044 \\
(0.028)\end{array}$ & $\begin{array}{l}-0.061 * * \\
(0.026)\end{array}$ & $\begin{array}{l}-0.054 * * \\
(0.024)\end{array}$ & $\begin{array}{l}-0.048 * * \\
(0.024)\end{array}$ & $\begin{array}{l}-0.049 * * \\
(0.023)\end{array}$ & $\begin{array}{l}-0.047 * * \\
(0.023)\end{array}$ & $\begin{array}{l}-0.042^{*} \\
(0.022)\end{array}$ & $\begin{array}{l}-0.039^{*} \\
(0.022)\end{array}$ & $\begin{array}{l}-0.039 * \\
(0.022)\end{array}$ \\
\hline Medium childhood HI & $\begin{array}{l}0.006 \\
(0.030)\end{array}$ & $\begin{array}{l}-0.027 \\
(0.027)\end{array}$ & $\begin{array}{l}-0.018 \\
(0.025)\end{array}$ & $\begin{array}{l}-0.013 \\
(0.025)\end{array}$ & $\begin{array}{l}-0.016 \\
(0.025)\end{array}$ & $\begin{array}{l}-0.014 \\
(0.024)\end{array}$ & $\begin{array}{l}-0.015 \\
(0.024)\end{array}$ & $\begin{array}{l}-0.013 \\
(0.023)\end{array}$ & $\begin{array}{l}-0.014 \\
(0.023)\end{array}$ \\
\hline Low childhood SES & $\begin{array}{l}-0.329 * * * \\
(0.030)\end{array}$ & $\begin{array}{l}-0.333^{* * *} \\
(0.029)\end{array}$ & $\begin{array}{l}-0.346^{* * *} \\
(0.027)\end{array}$ & $\begin{array}{l}-0.332 * * * \\
(0.027)\end{array}$ & $\begin{array}{l}-0.329 * * * \\
(0.026)\end{array}$ & $\begin{array}{l}-0.329 * * * \\
(0.025)\end{array}$ & $\begin{array}{l}-0.328^{* * *} \\
(0.025)\end{array}$ & $\begin{array}{l}-0.324 * * * \\
(0.024)\end{array}$ & $\begin{array}{l}-0.323^{* * *} \\
(0.024)\end{array}$ \\
\hline Medium childhood SES & $\begin{array}{l}-0.167 * * * \\
(0.025)\end{array}$ & $\begin{array}{l}-0.181 * * * \\
(0.023)\end{array}$ & $\begin{array}{l}-0.195^{* * *} \\
(0.022)\end{array}$ & $\begin{array}{l}-0.192 * * * \\
(0.021)\end{array}$ & $\begin{array}{l}-0.182 * * * \\
(0.021)\end{array}$ & $\begin{array}{l}-0.179 * * * \\
(0.020)\end{array}$ & $\begin{array}{l}-0.176^{* * *} \\
(0.020)\end{array}$ & $\begin{array}{l}-0.173 * * * \\
(0.019)\end{array}$ & $\begin{array}{l}-0.172 * * * \\
(0.019)\end{array}$ \\
\hline R-squared & 0.245 & 0.242 & 0.248 & 0.236 & 0.224 & 0.218 & 0.215 & 0.212 & 0.212 \\
\hline Observations & 6505 & 6849 & 6972 & 7063 & 7128 & 7160 & 7167 & 7169 & 7170 \\
\hline
\end{tabular}

a Based on the estimation of linear models on the logarithm of average annual earnings at different ages over an individual's working life using OLS. All models include country dummies and birth-year dummies. Robust standard errors in parentheses. Significance levels: $* * * \mathrm{p}<0.01 * * \mathrm{p}<0.05 * \mathrm{p}<0.10$. 
Table A.IX Log working years regressions over the life cycle for men and women in Europe (I)

\begin{tabular}{|c|c|c|c|c|c|c|c|c|c|}
\hline Men & $\begin{array}{l}\text { Until age } 25 \\
\text { (1) }\end{array}$ & $\begin{array}{l}\text { Until age } 30 \\
\text { (2) }\end{array}$ & $\begin{array}{l}\text { Until age } 35 \\
\text { (3) }\end{array}$ & $\begin{array}{l}\text { Until age } 40 \\
\text { (4) }\end{array}$ & $\begin{array}{l}\text { Until age } 45 \\
\text { (5) }\end{array}$ & $\begin{array}{l}\text { Until age } 50 \\
(6)\end{array}$ & $\begin{array}{l}\text { Until age } 55 \\
\text { (7) }\end{array}$ & $\begin{array}{l}\text { Until age } 60 \\
(8)\end{array}$ & $\begin{array}{l}\text { Until age } 65 \\
\text { (9) }\end{array}$ \\
\hline \multirow[t]{2}{*}{ Low childhood HI } & -0.000 & -0.015 & -0.010 & -0.007 & -0.004 & -0.002 & -0.004 & $-0.010^{*}$ & $-0.010^{*}$ \\
\hline & $(0.016)$ & $(0.013)$ & $(0.009)$ & $(0.007)$ & $(0.006)$ & $(0.005)$ & $(0.005)$ & $(0.006)$ & $(0.006)$ \\
\hline \multirow[t]{2}{*}{ Medium childhood HI } & -0.013 & $-0.030 * *$ & $-0.021 * *$ & $-0.016^{* *}$ & $-0.011^{*}$ & -0.005 & -0.004 & -0.002 & -0.003 \\
\hline & $(0.017)$ & $(0.013)$ & $(0.009)$ & $(0.007)$ & $(0.006)$ & $(0.006)$ & $(0.005)$ & $(0.006)$ & $(0.006)$ \\
\hline \multirow[t]{2}{*}{ Low childhood SES } & $0.438 * * *$ & $0.354 * * *$ & $0.229 * * *$ & $0.166^{* * *}$ & $0.128 * * *$ & $0.101 * * *$ & $0.080 * * *$ & $0.061 * * *$ & $0.045^{* * *}$ \\
\hline & $(0.020)$ & $(0.015)$ & $(0.010)$ & $(0.008)$ & $(0.006)$ & $(0.006)$ & $(0.006)$ & $(0.006)$ & $(0.007)$ \\
\hline \multirow[t]{2}{*}{ Medium childhood SES } & $0.294 * * *$ & $0.239 * * *$ & $0.158 * * *$ & $0.111^{* * *}$ & $0.090 * * *$ & $0.072 * * *$ & $0.062 * * *$ & $0.047 * * *$ & $0.040 * * *$ \\
\hline & $(0.019)$ & $(0.014)$ & $(0.009)$ & $(0.007)$ & $(0.006)$ & $(0.005)$ & $(0.005)$ & $(0.006)$ & $(0.006)$ \\
\hline R-squared & 0.133 & 0.125 & 0.121 & 0.106 & 0.095 & 0.081 & 0.066 & 0.056 & 0.063 \\
\hline Observations & 7060 & 7693 & 7772 & 7793 & 7798 & 7800 & 7800 & 7803 & 7803 \\
\hline Women & (1) & (2) & (3) & (4) & $(5)$ & (6) & (7) & (8) & (9) \\
\hline \multirow[t]{2}{*}{ Low childhood HI } & -0.001 & 0.001 & -0.016 & -0.015 & $-0.034 * *$ & $-0.038 * * *$ & $-0.037 * * *$ & $-0.041 * * *$ & $-0.038 * * *$ \\
\hline & $(0.016)$ & $(0.015)$ & $(0.014)$ & $(0.014)$ & $(0.014)$ & $(0.014)$ & $(0.014)$ & $(0.014)$ & $(0.014)$ \\
\hline \multirow[t]{2}{*}{ Medium childhood HI } & -0.003 & -0.008 & -0.015 & -0.022 & $-0.038 * *$ & $-0.033 * *$ & $-0.029 *$ & $-0.029 *$ & $-0.026^{*}$ \\
\hline & $(0.017)$ & $(0.016)$ & $(0.015)$ & $(0.016)$ & $(0.016)$ & $(0.015)$ & $(0.015)$ & $(0.015)$ & $(0.016)$ \\
\hline \multirow[t]{2}{*}{ Low childhood SES } & $0.315 * * *$ & $0.140 * * *$ & $0.060 * * *$ & 0.018 & -0.003 & $-0.041 * *$ & $-0.064 * * *$ & $-0.086^{* * *}$ & $-0.097 * * *$ \\
\hline & $(0.017)$ & $(0.016)$ & $(0.016)$ & $(0.016)$ & $(0.016)$ & $(0.016)$ & $(0.016)$ & $(0.016)$ & $(0.017)$ \\
\hline \multirow[t]{2}{*}{ Medium childhood SES } & $0.220 * * *$ & $0.130 * * *$ & $0.076^{* * *}$ & $0.046^{* * *}$ & $0.028 * *$ & 0.006 & -0.007 & -0.021 & $-0.031 * *$ \\
\hline & $(0.016)$ & $(0.014)$ & $(0.014)$ & $(0.014)$ & $(0.014)$ & $(0.014)$ & $(0.014)$ & $(0.014)$ & $(0.014)$ \\
\hline R-squared & 0.113 & 0.067 & 0.087 & 0.116 & 0.135 & 0.156 & 0.168 & 0.164 & 0.159 \\
\hline Observations & 6505 & 6849 & 6972 & 7063 & 7128 & 7160 & 7167 & 7169 & 7170 \\
\hline
\end{tabular}

${ }^{a}$ Based on the estimation of linear models on the logarithm of accumulated working years at different ages over an individual's working life using OLS. All models include country dummies and birth-year dummies. Robust standard errors in parentheses. Significance levels: $* * * \mathrm{p}<0.01 * * \mathrm{p}<0.05 * \mathrm{p}<0.10$. 
Table A.X Regressions on the number of employment gaps over the life cycle for men and women in Europe

\begin{tabular}{|c|c|c|c|c|c|c|c|c|c|}
\hline Men & $\begin{array}{l}\text { Until age } 25 \\
\text { (1) }\end{array}$ & $\begin{array}{l}\text { Until age } 30 \\
\text { (2) }\end{array}$ & $\begin{array}{l}\text { Until age } 35 \\
\text { (3) }\end{array}$ & $\begin{array}{l}\text { Until age } 40 \\
\text { (4) }\end{array}$ & $\begin{array}{l}\text { Until age } 45 \\
\text { (5) }\end{array}$ & $\begin{array}{l}\text { Until age } 50 \\
(6)\end{array}$ & $\begin{array}{l}\text { Until age } 55 \\
\text { (7) }\end{array}$ & $\begin{array}{l}\text { Until age } 60 \\
(8)\end{array}$ & $\begin{array}{l}\text { Until age } 65 \\
\text { (9) }\end{array}$ \\
\hline \multirow[t]{2}{*}{ Low childhood HI } & 0.110 & 0.276 & 0.287 & 0.323 & 0.248 & 0.319 & $0.477^{*}$ & $0.514 * *$ & $0.299 *$ \\
\hline & $(0.149)$ & $(0.169)$ & $(0.186)$ & $(0.207)$ & $(0.232)$ & $(0.259)$ & $(0.271)$ & $(0.238)$ & $(0.173)$ \\
\hline \multirow[t]{2}{*}{ Medium childhood HI } & -0.116 & -0.100 & -0.087 & -0.234 & -0.395 & $-0.513^{*}$ & -0.316 & -0.279 & -0.161 \\
\hline & $(0.159)$ & $(0.179)$ & $(0.196)$ & $(0.220)$ & $(0.247)$ & $(0.278)$ & $(0.288)$ & $(0.253)$ & $(0.178)$ \\
\hline \multirow[t]{2}{*}{ Low childhood SES } & $0.319^{*}$ & $0.334 *$ & $0.487 * *$ & $0.707^{* * *}$ & $0.902 * * *$ & $1.254 * * *$ & $1.635 * * *$ & $1.635 * * *$ & $0.949 * * *$ \\
\hline & $(0.171)$ & $(0.190)$ & $(0.212)$ & $(0.238)$ & $(0.267)$ & $(0.301)$ & $(0.315)$ & $(0.277)$ & $(0.199)$ \\
\hline \multirow[t]{2}{*}{ Medium childhood SES } & -0.070 & -0.210 & -0.233 & -0.245 & -0.337 & -0.318 & -0.169 & 0.196 & -0.045 \\
\hline & $(0.164)$ & $(0.182)$ & $(0.201)$ & $(0.224)$ & $(0.251)$ & $(0.280)$ & $(0.292)$ & $(0.252)$ & $(0.168)$ \\
\hline Pseudo R-squared & 0.018 & 0.015 & 0.013 & 0.013 & 0.014 & 0.016 & 0.017 & 0.016 & 0.016 \\
\hline Observations & 7060 & 7693 & 7772 & 7793 & 7798 & 7800 & 7800 & 7803 & 7803 \\
\hline Women & (1) & (2) & (3) & (4) & $(5)$ & (6) & (7) & (8) & (9) \\
\hline \multirow[t]{2}{*}{ Low childhood HI } & 0.192 & $0.357 * *$ & $0.504 * *$ & $0.622 * *$ & $0.615^{*}$ & $0.610^{*}$ & $0.719^{*}$ & $0.667^{*}$ & 0.526 \\
\hline & $(0.141)$ & $(0.170)$ & $(0.220)$ & $(0.270)$ & $(0.315)$ & $(0.354)$ & $(0.388)$ & $(0.388)$ & $(0.366)$ \\
\hline \multirow{2}{*}{ Medium childhood HI } & -0.138 & -0.011 & 0.099 & 0.078 & -0.130 & -0.277 & -0.217 & -0.309 & -0.282 \\
\hline & $(0.156)$ & $(0.192)$ & $(0.248)$ & $(0.303)$ & $(0.355)$ & $(0.399)$ & $(0.436)$ & $(0.431)$ & $(0.404)$ \\
\hline \multirow[t]{2}{*}{ Low childhood SES } & $1.968 * * *$ & $2.395 * * *$ & $2.830 * * *$ & $3.257 * * *$ & $3.747 * * *$ & $4.324 * * *$ & $5.033 * * *$ & $5.064 * * *$ & $4.614 * * *$ \\
\hline & $(0.157)$ & $(0.193)$ & $(0.250)$ & $(0.308)$ & $(0.361)$ & $(0.408)$ & $(0.447)$ & $(0.442)$ & $(0.425)$ \\
\hline \multirow[t]{2}{*}{ Medium childhood SES } & $0.989 * * *$ & $1.165^{* * *}$ & $1.355^{* * *}$ & $1.571^{* * *}$ & $1.820 * * *$ & $2.120 * * *$ & $2.511 * * *$ & $2.586^{* * *}$ & $2.346^{* * *}$ \\
\hline & $(0.142)$ & $(0.169)$ & $(0.216)$ & $(0.265)$ & $(0.311)$ & $(0.352)$ & $(0.385)$ & $(0.380)$ & $(0.355)$ \\
\hline Pseudo R-squared & 0.034 & 0.041 & 0.045 & 0.045 & 0.045 & 0.044 & 0.042 & 0.037 & 0.042 \\
\hline Observations & 6505 & 6849 & 6972 & 7063 & 7128 & 7160 & 7167 & 7169 & 7170 \\
\hline
\end{tabular}

${ }^{a}$ Marginal effects (conditional on being uncensored) obtained from the estimation of Tobit models on the (accumulated) number of employment gaps at different ages over an individual's working life. All models include country dummies and birth-year dummies. Robust standard errors in parentheses. Significance levels: $* * * \mathrm{p}<0.01 * * \mathrm{p}<0.05 *$ $\mathrm{p}<0.10$. 
Table A.XI Regressions on the probability of leaving the labor market over the life cycle for men and women in Europe ${ }^{\mathrm{a}}$

\begin{tabular}{|c|c|c|c|c|c|c|c|c|c|}
\hline Men & $\begin{array}{l}\text { Until age } 25 \\
\text { (1) }\end{array}$ & $\begin{array}{l}\text { Until age } 30 \\
\text { (2) }\end{array}$ & $\begin{array}{l}\text { Until age } 35 \\
\text { (3) }\end{array}$ & $\begin{array}{l}\text { Until age } 40 \\
\text { (4) }\end{array}$ & $\begin{array}{l}\text { Until age } 45 \\
\text { (5) }\end{array}$ & $\begin{array}{l}\text { Until age } 50 \\
(6)\end{array}$ & $\begin{array}{l}\text { Until age } 55 \\
\text { (7) }\end{array}$ & $\begin{array}{l}\text { Until age } 60 \\
(8)\end{array}$ & $\begin{array}{l}\text { Until age } 65 \\
\text { (9) }\end{array}$ \\
\hline \multirow[t]{2}{*}{ Low childhood HI } & -0.000 & $-0.001 *$ & -0.001 & 0.001 & 0.000 & -0.001 & 0.000 & 0.007 & -0.006 \\
\hline & $(0.000)$ & $(0.001)$ & $(0.001)$ & $(0.002)$ & $(0.003)$ & $(0.004)$ & $(0.008)$ & $(0.012)$ & $(0.008)$ \\
\hline \multirow[t]{2}{*}{ Medium childhood HI } & 0.000 & -0.000 & -0.000 & -0.002 & -0.003 & 0.001 & -0.001 & 0.009 & 0.010 \\
\hline & $(0.001)$ & $(0.001)$ & $(0.001)$ & $(0.002)$ & $(0.003)$ & $(0.005)$ & $(0.008)$ & $(0.012)$ & $(0.008)$ \\
\hline \multirow[t]{2}{*}{ Low childhood SES } & 0.001 & 0.000 & -0.000 & 0.001 & $0.006^{*}$ & 0.006 & $0.027 * * *$ & $0.087 * * *$ & $0.017 * *$ \\
\hline & $(0.001)$ & $(0.001)$ & $(0.001)$ & $(0.002)$ & $(0.003)$ & $(0.005)$ & $(0.009)$ & $(0.014)$ & $(0.009)$ \\
\hline \multirow[t]{2}{*}{ Medium childhood SES } & 0.000 & -0.000 & -0.000 & 0.002 & 0.002 & 0.004 & $0.015 * *$ & $0.051 * * *$ & $0.013^{*}$ \\
\hline & $(0.000)$ & $(0.001)$ & $(0.001)$ & $(0.002)$ & $(0.003)$ & $(0.004)$ & $(0.007)$ & $(0.012)$ & $(0.008)$ \\
\hline R-squared & 0.007 & 0.007 & 0.008 & 0.007 & 0.010 & 0.027 & 0.083 & 0.182 & 0.144 \\
\hline Observations & 7060 & 7693 & 7772 & 7793 & 7798 & 7800 & 7800 & 7803 & 7803 \\
\hline Women & $(1)$ & $(2)$ & (3) & $(4)$ & $(5)$ & (6) & $(7)$ & $(8)$ & $(9)$ \\
\hline \multirow[t]{2}{*}{ Low childhood HI } & $0.002 * *$ & $0.004 * * *$ & $0.005 * * *$ & $0.008 * * *$ & $0.014 * * *$ & $0.020 * * *$ & 0.008 & -0.011 & 0.003 \\
\hline & $(0.001)$ & $(0.001)$ & $(0.002)$ & $(0.002)$ & $(0.004)$ & $(0.005)$ & $(0.009)$ & $(0.011)$ & $(0.007)$ \\
\hline \multirow[t]{2}{*}{ Medium childhood HI } & $0.002^{*}$ & $0.003 * *$ & $0.004 * *$ & $0.006 * *$ & $0.009 * *$ & 0.007 & -0.002 & $-0.024 *$ & 0.005 \\
\hline & $(0.001)$ & $(0.001)$ & $(0.002)$ & $(0.003)$ & $(0.004)$ & $(0.006)$ & $(0.010)$ & $(0.012)$ & $(0.007)$ \\
\hline \multirow[t]{2}{*}{ Low childhood SES } & 0.002 & 0.001 & 0.002 & 0.003 & 0.005 & 0.004 & $0.028 * * *$ & $0.037 * * *$ & 0.006 \\
\hline & $(0.002)$ & $(0.002)$ & $(0.002)$ & $(0.004)$ & $(0.005)$ & $(0.007)$ & $(0.010)$ & $(0.013)$ & $(0.008)$ \\
\hline \multirow[t]{2}{*}{ Medium childhood SES } & $0.001 *$ & -0.000 & 0.001 & 0.001 & $0.006^{*}$ & 0.003 & $0.027 * * *$ & $0.046 * * *$ & 0.004 \\
\hline & $(0.001)$ & $(0.001)$ & $(0.002)$ & $(0.002)$ & $(0.004)$ & $(0.005)$ & $(0.008)$ & $(0.011)$ & $(0.007)$ \\
\hline R-squared & 0.008 & 0.008 & 0.006 & 0.008 & 0.014 & 0.028 & 0.136 & 0.404 & 0.144 \\
\hline Observations & 6505 & 6849 & 6972 & 7063 & 7128 & 7160 & 7167 & 7169 & 7170 \\
\hline
\end{tabular}

a Based on the estimation of linear models on the probability of leaving the labor market at different ages over an individual's working life using OLS. All models include country dummies and birth-year dummies. Robust standard errors in parentheses. Significance levels: ${ }^{* * *} \mathrm{p}<0.01 * * \mathrm{p}<0.05 * \mathrm{p}<0.10$. 
Table A.XII Log lifetime earnings regressions over the life cycle in Nordic, Continental, Mediterranean and Transitional countries (Men) ${ }^{\mathbf{a}}$

\begin{tabular}{|c|c|c|c|c|c|c|c|c|c|}
\hline Nordic & $\begin{array}{l}\leq 25 \\
(1)\end{array}$ & $\begin{array}{l}\leq 30 \\
(2)\end{array}$ & $\begin{array}{l}\leq 35 \\
(3)\end{array}$ & $\begin{array}{l}\leq 40 \\
(4)\end{array}$ & $\begin{array}{l}\leq 45 \\
(5)\end{array}$ & $\begin{array}{l}\leq 50 \\
(6)\end{array}$ & $\begin{array}{l}\leq 55 \\
(7)\end{array}$ & $\begin{array}{l}\leq 60 \\
(8)\end{array}$ & $\begin{array}{l}\leq 65 \\
(9)\end{array}$ \\
\hline \multirow[t]{2}{*}{ Low childhood HI } & -0.125 & $-0.151 *$ & $-0.108 *$ & -0.096 & -0.086 & -0.082 & -0.085 & -0.082 & -0.080 \\
\hline & $(0.080)$ & $(0.064)$ & $(0.054)$ & $(0.052)$ & $(0.050)$ & $(0.049)$ & $(0.048)$ & $(0.046)$ & $(0.045)$ \\
\hline \multirow[t]{2}{*}{ Medium childhood HI } & -0.125 & $-0.139 *$ & $-0.134 *$ & $-0.125 *$ & $-0.121 *$ & $-0.111 *$ & $-0.110 *$ & $-0.110 *$ & $-0.112 *$ \\
\hline & $(0.072)$ & $(0.059)$ & $(0.050)$ & $(0.048)$ & $(0.047)$ & $(0.046)$ & $(0.044)$ & $(0.043)$ & $(0.042)$ \\
\hline \multirow[t]{2}{*}{ Low childhood SES } & 0.146 & 0.049 & -0.080 & $-0.145^{*}$ & $-0.177 *$ & $-0.209^{*}$ & $-0.220 *$ & $-0.230 *$ & $-0.238^{*}$ \\
\hline & $(0.087)$ & $(0.069)$ & $(0.058)$ & $(0.056)$ & $(0.054)$ & $(0.053)$ & $(0.052)$ & $(0.050)$ & $(0.049)$ \\
\hline \multirow[t]{2}{*}{ Medium childhood SES } & 0.109 & 0.111 & 0.024 & -0.035 & -0.065 & -0.088 & $-0.099 *$ & $-0.106^{*}$ & $-0.110^{*}$ \\
\hline & $(0.082)$ & $(0.064)$ & $(0.053)$ & $(0.051)$ & $(0.049)$ & $(0.048)$ & $(0.046)$ & $(0.044)$ & $(0.043)$ \\
\hline R-squared & 0.036 & 0.033 & 0.039 & 0.045 & 0.053 & 0.064 & 0.076 & 0.075 & 0.074 \\
\hline Observations & 1181 & 1336 & 1360 & 1366 & 1367 & 1368 & 1368 & 1368 & 1368 \\
\hline Continental & $(1)$ & $(2)$ & (3) & $(4)$ & $(5)$ & $(6)$ & $(7)$ & $(8)$ & $(9)$ \\
\hline \multirow[t]{2}{*}{ Low childhood HI } & -0.047 & -0.027 & -0.035 & -0.026 & -0.029 & -0.027 & -0.026 & -0.027 & -0.028 \\
\hline & $(0.039)$ & $(0.031)$ & $(0.028)$ & $(0.027)$ & $(0.026)$ & $(0.025)$ & $(0.025)$ & $(0.025)$ & $(0.025)$ \\
\hline \multirow[t]{2}{*}{ Medium childhood HI } & -0.035 & -0.006 & -0.018 & -0.027 & -0.031 & -0.032 & -0.032 & -0.033 & -0.035 \\
\hline & $(0.043)$ & $(0.034)$ & $(0.032)$ & $(0.030)$ & $(0.029)$ & $(0.028)$ & $(0.028)$ & $(0.028)$ & $(0.028)$ \\
\hline \multirow[t]{2}{*}{ Low childhood SES } & $0.251 *$ & $0.093^{*}$ & -0.055 & $-0.128 *$ & $-0.168 *$ & $-0.197 *$ & $-0.219 *$ & $-0.239 *$ & $-0.253 *$ \\
\hline & $(0.044)$ & $(0.034)$ & $(0.031)$ & $(0.030)$ & $(0.029)$ & $(0.028)$ & $(0.028)$ & $(0.028)$ & $(0.028)$ \\
\hline \multirow[t]{2}{*}{ Medium childhood SES } & $0.215^{*}$ & $0.102 *$ & -0.001 & $-0.051 *$ & $-0.075 *$ & $-0.089 *$ & $-0.095 *$ & $-0.103 *$ & $-0.110^{*}$ \\
\hline & $(0.040)$ & $(0.031)$ & $(0.027)$ & $(0.026)$ & $(0.025)$ & $(0.024)$ & $(0.024)$ & $(0.024)$ & $(0.024)$ \\
\hline R-squared & 0.120 & 0.105 & 0.116 & 0.122 & 0.133 & 0.138 & 0.142 & 0.148 & 0.156 \\
\hline Observations & 3184 & 3455 & 3480 & 3486 & 3486 & 3486 & 3486 & 3486 & 3486 \\
\hline Mediterranean & $(1)$ & $(2)$ & $(3)$ & $(4)$ & $(5)$ & $(6)$ & $(7)$ & $(8)$ & $(9)$ \\
\hline \multirow[t]{2}{*}{ Low childhood HI } & -0.138 & $-0.155^{*}$ & $-0.155^{*}$ & $-0.137 *$ & $-0.129 *$ & $-0.124 *$ & $-0.128 *$ & $-0.147 *$ & $-0.148^{*}$ \\
\hline & $(0.076)$ & $(0.066)$ & $(0.057)$ & $(0.053)$ & $(0.051)$ & $(0.049)$ & $(0.047)$ & $(0.048)$ & $(0.047)$ \\
\hline \multirow[t]{2}{*}{ Medium childhood HI } & 0.022 & 0.008 & 0.007 & 0.007 & 0.005 & 0.010 & 0.006 & 0.009 & 0.008 \\
\hline & $(0.077)$ & $(0.065)$ & $(0.057)$ & $(0.053)$ & $(0.051)$ & $(0.049)$ & $(0.047)$ & $(0.046)$ & $(0.045)$ \\
\hline \multirow[t]{2}{*}{ Low childhood SES } & $0.167^{*}$ & 0.086 & -0.050 & -0.095 & $-0.126^{*}$ & $-0.139 *$ & $-0.158 *$ & $-0.170 *$ & $-0.179 *$ \\
\hline & $(0.078)$ & $(0.066)$ & $(0.056)$ & $(0.052)$ & $(0.050)$ & $(0.048)$ & $(0.047)$ & $(0.046)$ & $(0.046)$ \\
\hline \multirow[t]{2}{*}{ Medium childhood SES } & 0.069 & 0.045 & -0.049 & -0.087 & $-0.107 *$ & $-0.114 *$ & $-0.127 *$ & $-0.143^{*}$ & $-0.142 *$ \\
\hline & $(0.076)$ & $(0.064)$ & $(0.054)$ & $(0.051)$ & $(0.049)$ & $(0.048)$ & $(0.046)$ & $(0.046)$ & $(0.045)$ \\
\hline R-squared & 0.092 & 0.101 & 0.103 & 0.110 & 0.115 & 0.114 & 0.120 & 0.120 & 0.128 \\
\hline Observations & 1686 & 1867 & 1894 & 1902 & 1906 & 1907 & 1907 & 1910 & 1910 \\
\hline Transitional & $(1)$ & $(2)$ & (3) & (4) & (5) & $(6)$ & $(7)$ & $(8)$ & (9) \\
\hline \multirow[t]{2}{*}{ Low childhood HI } & 0.038 & 0.028 & 0.060 & 0.061 & 0.064 & 0.068 & 0.059 & 0.050 & 0.050 \\
\hline & $(0.069)$ & $(0.059)$ & $(0.056)$ & $(0.058)$ & $(0.061)$ & $(0.062)$ & $(0.062)$ & $(0.062)$ & $(0.061)$ \\
\hline \multirow[t]{2}{*}{ Medium childhood HI } & 0.072 & 0.053 & 0.072 & 0.062 & 0.060 & 0.061 & 0.060 & 0.062 & 0.063 \\
\hline & $(0.066)$ & $(0.058)$ & $(0.056)$ & $(0.057)$ & $(0.058)$ & $(0.058)$ & $(0.058)$ & $(0.058)$ & $(0.059)$ \\
\hline \multirow[t]{2}{*}{ Low childhood SES } & 0.082 & -0.069 & $-0.141 *$ & $-0.162 *$ & $-0.182 *$ & $-0.201 *$ & $-0.213 *$ & $-0.214 *$ & $-0.218^{*}$ \\
\hline & $(0.080)$ & $(0.068)$ & $(0.063)$ & $(0.065)$ & $(0.065)$ & $(0.066)$ & $(0.065)$ & $(0.064)$ & $(0.064)$ \\
\hline \multirow[t]{2}{*}{ Medium childhood SES } & $0.195^{*}$ & 0.054 & -0.022 & -0.054 & -0.076 & -0.095 & $-0.104 *$ & $-0.108 *$ & $-0.114^{*}$ \\
\hline & $(0.067)$ & $(0.056)$ & $(0.051)$ & $(0.052)$ & $(0.052)$ & $(0.053)$ & $(0.052)$ & $(0.051)$ & $(0.051)$ \\
\hline R-squared & 0.151 & 0.155 & 0.156 & 0.127 & 0.106 & 0.092 & 0.088 & 0.091 & 0.091 \\
\hline Observations & 1009 & 1035 & 1038 & 1039 & 1039 & 1039 & 1039 & 1039 & 1039 \\
\hline
\end{tabular}


Table A.XII Continued (Women) ${ }^{\mathrm{a}}$

\begin{tabular}{|c|c|c|c|c|c|c|c|c|c|}
\hline Nordic & $\begin{array}{l}\leq 25 \\
(1)\end{array}$ & $\begin{array}{l}\leq 30 \\
(2)\end{array}$ & $\begin{array}{l}\leq 35 \\
(3)\end{array}$ & $\begin{array}{l}\leq 40 \\
(4)\end{array}$ & $\begin{array}{l}\leq 45 \\
(5)\end{array}$ & $\begin{array}{l}\leq 50 \\
(6)\end{array}$ & $\begin{array}{l}\leq 55 \\
(7)\end{array}$ & $\begin{array}{l}\leq 60 \\
(8)\end{array}$ & $\begin{array}{l}\leq 65 \\
(9)\end{array}$ \\
\hline Low childhood $\mathrm{HI}$ & $\begin{array}{l}-0.056 \\
(0.076)\end{array}$ & $\begin{array}{l}-0.103 \\
(0.068)\end{array}$ & $\begin{array}{l}-0.068 \\
(0.062)\end{array}$ & $\begin{array}{l}-0.067 \\
(0.059)\end{array}$ & $\begin{array}{l}-0.050 \\
(0.057)\end{array}$ & $\begin{array}{l}-0.066 \\
(0.057)\end{array}$ & $\begin{array}{l}-0.062 \\
(0.054)\end{array}$ & $\begin{array}{l}-0.064 \\
(0.052)\end{array}$ & $\begin{array}{l}-0.067 \\
(0.052)\end{array}$ \\
\hline Medium childhood HI & $\begin{array}{l}-0.009 \\
(0.073)\end{array}$ & $\begin{array}{l}-0.046 \\
(0.065)\end{array}$ & $\begin{array}{l}-0.063 \\
(0.060)\end{array}$ & $\begin{array}{l}-0.076 \\
(0.057)\end{array}$ & $\begin{array}{l}-0.099 \\
(0.059)\end{array}$ & $\begin{array}{l}-0.089 \\
(0.056)\end{array}$ & $\begin{array}{l}-0.107^{*} \\
(0.054)\end{array}$ & $\begin{array}{l}-0.109 * \\
(0.052)\end{array}$ & $\begin{array}{l}-0.112 * \\
(0.051)\end{array}$ \\
\hline Low childhood SES & $\begin{array}{l}0.230^{*} \\
(0.079)\end{array}$ & $\begin{array}{l}0.038 \\
(0.067)\end{array}$ & $\begin{array}{l}-0.071 \\
(0.062)\end{array}$ & $\begin{array}{l}-0.104 \\
(0.060)\end{array}$ & $\begin{array}{l}-0.129 * \\
(0.058)\end{array}$ & $\begin{array}{l}-0.177^{*} \\
(0.058)\end{array}$ & $\begin{array}{l}-0.196^{*} \\
(0.056)\end{array}$ & $\begin{array}{l}-0.218^{*} \\
(0.055)\end{array}$ & $\begin{array}{l}-0.234^{*} \\
(0.054)\end{array}$ \\
\hline Medium childhood SES & $\begin{array}{l}0.290^{*} \\
(0.082)\end{array}$ & $\begin{array}{l}0.110 \\
(0.070)\end{array}$ & $\begin{array}{l}0.011 \\
(0.062)\end{array}$ & $\begin{array}{l}-0.018 \\
(0.059)\end{array}$ & $\begin{array}{l}-0.064 \\
(0.060)\end{array}$ & $\begin{array}{l}-0.075 \\
(0.056)\end{array}$ & $\begin{array}{l}-0.077 \\
(0.053)\end{array}$ & $\begin{array}{l}-0.086 \\
(0.051)\end{array}$ & $\begin{array}{l}-0.100^{*} \\
(0.050)\end{array}$ \\
\hline $\begin{array}{l}\text { R-squared } \\
\text { Observations }\end{array}$ & $\begin{array}{l}0.043 \\
1312\end{array}$ & $\begin{array}{l}0.028 \\
1405\end{array}$ & $\begin{array}{l}0.034 \\
1427\end{array}$ & $\begin{array}{l}0.040 \\
1444\end{array}$ & $\begin{array}{l}0.035 \\
1462\end{array}$ & $\begin{array}{l}0.034 \\
1468\end{array}$ & $\begin{array}{l}0.036 \\
1469\end{array}$ & $\begin{array}{l}0.043 \\
1469\end{array}$ & $\begin{array}{l}0.049 \\
1469\end{array}$ \\
\hline Continental & (1) & (2) & (3) & (4) & (5) & (6) & (7) & $(8)$ & (9) \\
\hline Low childhood $\mathrm{HI}$ & $\begin{array}{l}-0.087^{*} \\
(0.038)\end{array}$ & $\begin{array}{l}-0.070 \\
(0.037)\end{array}$ & $\begin{array}{l}-0.092 * \\
(0.038)\end{array}$ & $\begin{array}{l}-0.075^{*} \\
(0.038)\end{array}$ & $\begin{array}{l}-0.079 * \\
(0.038)\end{array}$ & $\begin{array}{l}-0.076^{*} \\
(0.037)\end{array}$ & $\begin{array}{l}-0.067 \\
(0.037)\end{array}$ & $\begin{array}{l}-0.067 \\
(0.037)\end{array}$ & $\begin{array}{l}-0.067 \\
(0.037)\end{array}$ \\
\hline Medium childhood HI & $\begin{array}{l}-0.025 \\
(0.040)\end{array}$ & $\begin{array}{l}-0.028 \\
(0.041)\end{array}$ & $\begin{array}{l}-0.054 \\
(0.042)\end{array}$ & $\begin{array}{l}-0.064 \\
(0.043)\end{array}$ & $\begin{array}{l}-0.072 \\
(0.042)\end{array}$ & $\begin{array}{l}-0.073 \\
(0.042)\end{array}$ & $\begin{array}{l}-0.064 \\
(0.042)\end{array}$ & $\begin{array}{l}-0.062 \\
(0.042)\end{array}$ & $\begin{array}{l}-0.059 \\
(0.042)\end{array}$ \\
\hline Low childhood SES & $\begin{array}{l}-0.152^{*} \\
(0.041)\end{array}$ & $\begin{array}{l}-0.288^{*} \\
(0.040)\end{array}$ & $\begin{array}{l}-0.361 * \\
(0.041)\end{array}$ & $\begin{array}{l}-0.374 * \\
(0.042)\end{array}$ & $\begin{array}{l}-0.394^{*} \\
(0.041)\end{array}$ & $\begin{array}{l}-0.421 * \\
(0.041)\end{array}$ & $\begin{array}{l}-0.438^{*} \\
(0.041)\end{array}$ & $\begin{array}{l}-0.455^{*} \\
(0.042)\end{array}$ & $\begin{array}{l}-0.463 * \\
(0.042)\end{array}$ \\
\hline Medium childhood SES & $\begin{array}{l}-0.005 \\
(0.037)\end{array}$ & $\begin{array}{l}-0.104 * \\
(0.037)\end{array}$ & $\begin{array}{l}-0.147^{*} \\
(0.037)\end{array}$ & $\begin{array}{l}-0.155^{*} \\
(0.038)\end{array}$ & $\begin{array}{l}-0.182 * \\
(0.038)\end{array}$ & $\begin{array}{l}-0.192 * \\
(0.037)\end{array}$ & $\begin{array}{l}-0.198^{*} \\
(0.037)\end{array}$ & $\begin{array}{l}-0.208^{*} \\
(0.037)\end{array}$ & $\begin{array}{l}-0.212^{*} \\
(0.037)\end{array}$ \\
\hline $\begin{array}{l}\text { R-squared } \\
\text { Observations }\end{array}$ & $\begin{array}{l}0.130 \\
3046\end{array}$ & $\begin{array}{l}0.153 \\
3134\end{array}$ & $\begin{array}{l}0.166 \\
3165\end{array}$ & $\begin{array}{l}0.174 \\
3191\end{array}$ & $\begin{array}{l}0.180 \\
3203\end{array}$ & $\begin{array}{l}0.190 \\
3207\end{array}$ & $\begin{array}{l}0.195 \\
3209\end{array}$ & $\begin{array}{l}0.200 \\
3209\end{array}$ & $\begin{array}{l}0.201 \\
3209\end{array}$ \\
\hline Mediterranean & (1) & (2) & (3) & (4) & (5) & (6) & (7) & $(8)$ & (9) \\
\hline Low childhood HI & $\begin{array}{l}-0.098 \\
(0.092)\end{array}$ & $\begin{array}{l}-0.148 \\
(0.088)\end{array}$ & $\begin{array}{l}-0.184^{*} \\
(0.080)\end{array}$ & $\begin{array}{l}-0.137 \\
(0.085)\end{array}$ & $\begin{array}{l}-0.212^{*} \\
(0.079)\end{array}$ & $\begin{array}{l}-0.240^{*} \\
(0.079)\end{array}$ & $\begin{array}{l}-0.238^{*} \\
(0.078)\end{array}$ & $\begin{array}{l}-0.246^{*} \\
(0.079)\end{array}$ & $\begin{array}{l}-0.234^{*} \\
(0.079)\end{array}$ \\
\hline Medium childhood HI & $\begin{array}{l}0.016 \\
(0.100)\end{array}$ & $\begin{array}{l}0.017 \\
(0.089)\end{array}$ & $\begin{array}{l}-0.068 \\
(0.085)\end{array}$ & $\begin{array}{l}-0.022 \\
(0.087)\end{array}$ & $\begin{array}{l}-0.133 \\
(0.084)\end{array}$ & $\begin{array}{l}-0.134 \\
(0.082)\end{array}$ & $\begin{array}{l}-0.131 \\
(0.081)\end{array}$ & $\begin{array}{l}-0.140 \\
(0.081)\end{array}$ & $\begin{array}{l}-0.130 \\
(0.081)\end{array}$ \\
\hline Low childhood SES & $\begin{array}{l}0.185 \\
(0.096)\end{array}$ & $\begin{array}{l}-0.074 \\
(0.090)\end{array}$ & $\begin{array}{l}-0.211^{*} \\
(0.086)\end{array}$ & $\begin{array}{l}-0.290^{*} \\
(0.093)\end{array}$ & $\begin{array}{l}-0.329^{*} \\
(0.086)\end{array}$ & $\begin{array}{l}-0.404^{*} \\
(0.085)\end{array}$ & $\begin{array}{l}-0.429^{*} \\
(0.084)\end{array}$ & $\begin{array}{l}-0.459^{*} \\
(0.085)\end{array}$ & $\begin{array}{l}-0.465^{*} \\
(0.085)\end{array}$ \\
\hline Medium childhood SES & $\begin{array}{l}0.231 * \\
(0.094)\end{array}$ & $\begin{array}{l}-0.025 \\
(0.090)\end{array}$ & $\begin{array}{l}-0.078 \\
(0.083)\end{array}$ & $\begin{array}{l}-0.067 \\
(0.083)\end{array}$ & $\begin{array}{l}-0.112 \\
(0.081)\end{array}$ & $\begin{array}{l}-0.167 * \\
(0.080)\end{array}$ & $\begin{array}{l}-0.180 * \\
(0.078)\end{array}$ & $\begin{array}{l}-0.178^{*} \\
(0.078)\end{array}$ & $\begin{array}{l}-0.185^{*} \\
(0.078)\end{array}$ \\
\hline $\begin{array}{l}\text { R-squared } \\
\text { Observations }\end{array}$ & $\begin{array}{l}0.116 \\
969\end{array}$ & $\begin{array}{l}0.117 \\
1089\end{array}$ & $\begin{array}{l}0.135 \\
1146\end{array}$ & $\begin{array}{l}0.134 \\
1189\end{array}$ & $\begin{array}{l}0.147 \\
1218\end{array}$ & $\begin{array}{l}0.144 \\
1239\end{array}$ & $\begin{array}{l}0.149 \\
1243\end{array}$ & $\begin{array}{l}0.156 \\
1245\end{array}$ & $\begin{array}{l}0.155 \\
1246\end{array}$ \\
\hline Transitional & (1) & (2) & (3) & (4) & $(5)$ & (6) & (7) & $(8)$ & (9) \\
\hline Low childhood HI & $\begin{array}{l}0.005 \\
(0.062)\end{array}$ & $\begin{array}{l}-0.015 \\
(0.058)\end{array}$ & $\begin{array}{l}0.044 \\
(0.058)\end{array}$ & $\begin{array}{l}0.031 \\
(0.058)\end{array}$ & $\begin{array}{l}0.010 \\
(0.062)\end{array}$ & $\begin{array}{l}0.031 \\
(0.062)\end{array}$ & $\begin{array}{l}0.026 \\
(0.061)\end{array}$ & $\begin{array}{l}0.019 \\
(0.061)\end{array}$ & $\begin{array}{l}0.016 \\
(0.061)\end{array}$ \\
\hline Medium childhood HI & $\begin{array}{l}-0.006 \\
(0.062)\end{array}$ & $\begin{array}{l}-0.087 \\
(0.060)\end{array}$ & $\begin{array}{l}-0.003 \\
(0.055)\end{array}$ & $\begin{array}{l}0.010 \\
(0.055)\end{array}$ & $\begin{array}{l}0.019 \\
(0.058)\end{array}$ & $\begin{array}{l}0.043 \\
(0.058)\end{array}$ & $\begin{array}{l}0.043 \\
(0.058)\end{array}$ & $\begin{array}{l}0.042 \\
(0.057)\end{array}$ & $\begin{array}{l}0.039 \\
(0.057)\end{array}$ \\
\hline Low childhood SES & $\begin{array}{l}-0.180^{*} \\
(0.076)\end{array}$ & $\begin{array}{l}-0.287^{*} \\
(0.075)\end{array}$ & $\begin{array}{l}-0.321^{*} \\
(0.065)\end{array}$ & $\begin{array}{l}-0.275^{*} \\
(0.070)\end{array}$ & $\begin{array}{l}-0.285^{*} \\
(0.069)\end{array}$ & $\begin{array}{l}-0.281 * \\
(0.068)\end{array}$ & $\begin{array}{l}-0.280^{*} \\
(0.068)\end{array}$ & $\begin{array}{l}-0.297^{*} \\
(0.067)\end{array}$ & $\begin{array}{l}-0.300^{*} \\
(0.067)\end{array}$ \\
\hline Medium childhood SES & $\begin{array}{l}-0.013 \\
(0.058)\end{array}$ & $\begin{array}{l}-0.017 \\
(0.056)\end{array}$ & $\begin{array}{l}-0.068 \\
(0.050)\end{array}$ & $\begin{array}{l}-0.061 \\
(0.052)\end{array}$ & $\begin{array}{l}-0.064 \\
(0.051)\end{array}$ & $\begin{array}{l}-0.060 \\
(0.050)\end{array}$ & $\begin{array}{l}-0.061 \\
(0.049)\end{array}$ & $\begin{array}{l}-0.072 \\
(0.049)\end{array}$ & $\begin{array}{l}-0.073 \\
(0.049)\end{array}$ \\
\hline R-squared & 0.222 & 0.239 & 0.236 & 0.199 & 0.172 & 0.157 & 0.156 & 0.164 & 0.165 \\
\hline Observations & 1178 & 1221 & 1234 & 1239 & 1245 & 1246 & 1246 & 1246 & 1246 \\
\hline
\end{tabular}


Table A.XIII Log annual earnings regressions over the life cycle in Nordic, Continental, Mediterranean and Transitional countries (Men) ${ }^{\mathrm{a}}$

\begin{tabular}{|c|c|c|c|c|c|c|c|c|c|}
\hline Nordic & $\begin{array}{l}\leq 25 \\
(1)\end{array}$ & $\begin{array}{l}\leq 30 \\
(2)\end{array}$ & $\begin{array}{l}\leq 35 \\
(3)\end{array}$ & $\begin{array}{l}\leq 40 \\
(4)\end{array}$ & $\begin{array}{l}\leq 45 \\
(5)\end{array}$ & $\begin{array}{l}\leq 50 \\
(6)\end{array}$ & $\begin{array}{l}\leq 55 \\
(7)\end{array}$ & $\begin{array}{l}\leq 60 \\
(8)\end{array}$ & $\begin{array}{l}\leq 65 \\
(9)\end{array}$ \\
\hline Low childhood HI & $\begin{array}{l}-0.111 \\
(0.071)\end{array}$ & $\begin{array}{l}-0.060 \\
(0.060)\end{array}$ & $\begin{array}{l}-0.071 \\
(0.054)\end{array}$ & $\begin{array}{l}-0.059 \\
(0.052)\end{array}$ & $\begin{array}{l}-0.060 \\
(0.051)\end{array}$ & $\begin{array}{l}-0.063 \\
(0.050)\end{array}$ & $\begin{array}{l}-0.068 \\
(0.048)\end{array}$ & $\begin{array}{l}-0.065 \\
(0.047)\end{array}$ & $\begin{array}{l}-0.063 \\
(0.046)\end{array}$ \\
\hline Medium childhood HI & $\begin{array}{l}-0.116 \\
(0.063)\end{array}$ & $\begin{array}{l}-0.105 \\
(0.054)\end{array}$ & $\begin{array}{l}-0.109^{*} \\
(0.048)\end{array}$ & $\begin{array}{l}-0.103 * \\
(0.047)\end{array}$ & $\begin{array}{l}-0.097 * \\
(0.047)\end{array}$ & $\begin{array}{l}-0.094^{*} \\
(0.046)\end{array}$ & $\begin{array}{l}-0.093 * \\
(0.044)\end{array}$ & $\begin{array}{l}-0.092^{*} \\
(0.043)\end{array}$ & $\begin{array}{l}-0.090^{*} \\
(0.042)\end{array}$ \\
\hline Low childhood SES & $\begin{array}{l}-0.331^{*} \\
(0.077)\end{array}$ & $\begin{array}{l}-0.370^{*} \\
(0.064)\end{array}$ & $\begin{array}{l}-0.357^{*} \\
(0.057)\end{array}$ & $\begin{array}{l}-0.346^{*} \\
(0.056)\end{array}$ & $\begin{array}{l}-0.341^{*} \\
(0.055)\end{array}$ & $\begin{array}{l}-0.332 * \\
(0.054)\end{array}$ & $\begin{array}{l}-0.324 * \\
(0.052)\end{array}$ & $\begin{array}{l}-0.313^{*} \\
(0.050)\end{array}$ & $\begin{array}{l}-0.303 * \\
(0.049)\end{array}$ \\
\hline Medium childhood SES & $\begin{array}{l}-0.144^{*} \\
(0.070)\end{array}$ & $\begin{array}{l}-0.190^{*} \\
(0.059)\end{array}$ & $\begin{array}{l}-0.174^{*} \\
(0.052)\end{array}$ & $\begin{array}{l}-0.175^{*} \\
(0.050)\end{array}$ & $\begin{array}{l}-0.177^{*} \\
(0.049)\end{array}$ & $\begin{array}{l}-0.175^{*} \\
(0.048)\end{array}$ & $\begin{array}{l}-0.172 * \\
(0.046)\end{array}$ & $\begin{array}{l}-0.167^{*} \\
(0.045)\end{array}$ & $\begin{array}{l}-0.162 * \\
(0.044)\end{array}$ \\
\hline $\begin{array}{l}\text { R-squared } \\
\text { Observations }\end{array}$ & $\begin{array}{l}0.047 \\
1181\end{array}$ & $\begin{array}{l}0.057 \\
1336\end{array}$ & $\begin{array}{l}0.063 \\
1360\end{array}$ & $\begin{array}{l}0.062 \\
1366\end{array}$ & $\begin{array}{l}0.066 \\
1367\end{array}$ & $\begin{array}{l}0.071 \\
1368\end{array}$ & $\begin{array}{l}0.079 \\
1368\end{array}$ & $\begin{array}{l}0.078 \\
1368\end{array}$ & $\begin{array}{l}0.075 \\
1368\end{array}$ \\
\hline Continental & $(1)$ & $(2)$ & (3) & (4) & $(5)$ & (6) & (7) & $(8)$ & (9) \\
\hline Low childhood HI & $\begin{array}{l}-0.023 \\
(0.034)\end{array}$ & $\begin{array}{l}-0.023 \\
(0.029)\end{array}$ & $\begin{array}{l}-0.020 \\
(0.028)\end{array}$ & $\begin{array}{l}-0.016 \\
(0.027)\end{array}$ & $\begin{array}{l}-0.019 \\
(0.026)\end{array}$ & $\begin{array}{l}-0.019 \\
(0.025)\end{array}$ & $\begin{array}{l}-0.017 \\
(0.025)\end{array}$ & $\begin{array}{l}-0.015 \\
(0.025)\end{array}$ & $\begin{array}{l}-0.016 \\
(0.025)\end{array}$ \\
\hline Medium childhood HI & $\begin{array}{l}-0.016 \\
(0.037)\end{array}$ & $\begin{array}{l}-0.012 \\
(0.033)\end{array}$ & $\begin{array}{l}-0.020 \\
(0.031)\end{array}$ & $\begin{array}{l}-0.021 \\
(0.030)\end{array}$ & $\begin{array}{l}-0.026 \\
(0.029)\end{array}$ & $\begin{array}{l}-0.026 \\
(0.028)\end{array}$ & $\begin{array}{l}-0.026 \\
(0.028)\end{array}$ & $\begin{array}{l}-0.027 \\
(0.027)\end{array}$ & $\begin{array}{l}-0.028 \\
(0.027)\end{array}$ \\
\hline Low childhood SES & $\begin{array}{l}-0.190^{*} \\
(0.038)\end{array}$ & $\begin{array}{l}-0.278^{*} \\
(0.032)\end{array}$ & $\begin{array}{l}-0.293^{*} \\
(0.031)\end{array}$ & $\begin{array}{l}-0.303^{*} \\
(0.030)\end{array}$ & $\begin{array}{l}-0.305^{*} \\
(0.029)\end{array}$ & $\begin{array}{l}-0.308^{*} \\
(0.029)\end{array}$ & $\begin{array}{l}-0.307^{*} \\
(0.028)\end{array}$ & $\begin{array}{l}-0.306^{*} \\
(0.028)\end{array}$ & $\begin{array}{l}-0.303 * \\
(0.028)\end{array}$ \\
\hline Medium childhood SES & $\begin{array}{l}-0.073 * \\
(0.033)\end{array}$ & $\begin{array}{l}-0.147^{*} \\
(0.027)\end{array}$ & $\begin{array}{l}-0.158^{*} \\
(0.026)\end{array}$ & $\begin{array}{l}-0.165^{*} \\
(0.025)\end{array}$ & $\begin{array}{l}-0.167 * \\
(0.025)\end{array}$ & $\begin{array}{l}-0.167^{*} \\
(0.025)\end{array}$ & $\begin{array}{l}-0.165^{*} \\
(0.024)\end{array}$ & $\begin{array}{l}-0.162^{*} \\
(0.024)\end{array}$ & $\begin{array}{l}-0.161 * \\
(0.024)\end{array}$ \\
\hline $\begin{array}{l}\text { R-squared } \\
\text { Observations }\end{array}$ & $\begin{array}{l}0.201 \\
3184\end{array}$ & $\begin{array}{l}0.188 \\
3455\end{array}$ & $\begin{array}{l}0.182 \\
3480\end{array}$ & $\begin{array}{l}0.176 \\
3486\end{array}$ & $\begin{array}{l}0.179 \\
3486\end{array}$ & $\begin{array}{l}0.177 \\
3486\end{array}$ & $\begin{array}{l}0.174 \\
3486\end{array}$ & $\begin{array}{l}0.171 \\
3486\end{array}$ & $\begin{array}{l}0.167 \\
3486\end{array}$ \\
\hline Mediterranean & $(1)$ & $(2)$ & (3) & (4) & $(5)$ & (6) & (7) & $(8)$ & (9) \\
\hline Low childhood HI & $\begin{array}{l}-0.167 * \\
(0.068)\end{array}$ & $\begin{array}{l}-0.163^{*} \\
(0.059)\end{array}$ & $\begin{array}{l}-0.142^{*} \\
(0.054)\end{array}$ & $\begin{array}{l}-0.133^{*} \\
(0.052)\end{array}$ & $\begin{array}{l}-0.129 * \\
(0.049)\end{array}$ & $\begin{array}{l}-0.124^{*} \\
(0.048)\end{array}$ & $\begin{array}{l}-0.124 * \\
(0.046)\end{array}$ & $\begin{array}{l}-0.125^{*} \\
(0.045)\end{array}$ & $\begin{array}{l}-0.125^{*} \\
(0.044)\end{array}$ \\
\hline Medium childhood HI & $\begin{array}{l}0.041 \\
(0.070)\end{array}$ & $\begin{array}{l}0.036 \\
(0.060)\end{array}$ & $\begin{array}{l}0.034 \\
(0.055)\end{array}$ & $\begin{array}{l}0.029 \\
(0.052)\end{array}$ & $\begin{array}{l}0.025 \\
(0.049)\end{array}$ & $\begin{array}{l}0.022 \\
(0.047)\end{array}$ & $\begin{array}{l}0.015 \\
(0.046)\end{array}$ & $\begin{array}{l}0.014 \\
(0.044)\end{array}$ & $\begin{array}{l}0.011 \\
(0.043)\end{array}$ \\
\hline Low childhood SES & $\begin{array}{l}-0.223^{*} \\
(0.070)\end{array}$ & $\begin{array}{l}-0.232 * \\
(0.060)\end{array}$ & $\begin{array}{l}-0.243 * \\
(0.054)\end{array}$ & $\begin{array}{l}-0.237^{*} \\
(0.051)\end{array}$ & $\begin{array}{l}-0.233^{*} \\
(0.049)\end{array}$ & $\begin{array}{l}-0.231 * \\
(0.047)\end{array}$ & $\begin{array}{l}-0.232 * \\
(0.045)\end{array}$ & $\begin{array}{l}-0.227^{*} \\
(0.044)\end{array}$ & $\begin{array}{l}-0.225^{*} \\
(0.043)\end{array}$ \\
\hline Medium childhood SES & $\begin{array}{l}-0.186^{*} \\
(0.067)\end{array}$ & $\begin{array}{l}-0.196^{*} \\
(0.058)\end{array}$ & $\begin{array}{l}-0.206^{*} \\
(0.053)\end{array}$ & $\begin{array}{l}-0.194 * \\
(0.050)\end{array}$ & $\begin{array}{l}-0.188^{*} \\
(0.048)\end{array}$ & $\begin{array}{l}-0.184 * \\
(0.047)\end{array}$ & $\begin{array}{l}-0.183 * \\
(0.045)\end{array}$ & $\begin{array}{l}-0.181^{*} \\
(0.044)\end{array}$ & $\begin{array}{l}-0.178 * \\
(0.043)\end{array}$ \\
\hline $\begin{array}{l}\text { R-squared } \\
\text { Observations }\end{array}$ & $\begin{array}{l}0.135 \\
1686\end{array}$ & $\begin{array}{l}0.143 \\
1867\end{array}$ & $\begin{array}{l}0.142 \\
1894\end{array}$ & $\begin{array}{l}0.141 \\
1902\end{array}$ & $\begin{array}{l}0.140 \\
1906\end{array}$ & $\begin{array}{l}0.140 \\
1907\end{array}$ & $\begin{array}{l}0.142 \\
1907\end{array}$ & $\begin{array}{l}0.140 \\
1910\end{array}$ & $\begin{array}{l}0.138 \\
1910\end{array}$ \\
\hline Transitional & (1) & $(2)$ & (3) & (4) & $(5)$ & (6) & (7) & $(8)$ & (9) \\
\hline Low childhood HI & $\begin{array}{l}0.038 \\
(0.059)\end{array}$ & $\begin{array}{l}0.038 \\
(0.055)\end{array}$ & $\begin{array}{l}0.053 \\
(0.053)\end{array}$ & $\begin{array}{l}0.055 \\
(0.057)\end{array}$ & $\begin{array}{l}0.055 \\
(0.059)\end{array}$ & $\begin{array}{l}0.054 \\
(0.060)\end{array}$ & $\begin{array}{l}0.049 \\
(0.060)\end{array}$ & $\begin{array}{l}0.046 \\
(0.059)\end{array}$ & $\begin{array}{l}0.047 \\
(0.059)\end{array}$ \\
\hline Medium childhood HI & $\begin{array}{l}0.047 \\
(0.055)\end{array}$ & $\begin{array}{l}0.046 \\
(0.053)\end{array}$ & $\begin{array}{l}0.051 \\
(0.053)\end{array}$ & $\begin{array}{l}0.044 \\
(0.055)\end{array}$ & $\begin{array}{l}0.036 \\
(0.056)\end{array}$ & $\begin{array}{l}0.030 \\
(0.057)\end{array}$ & $\begin{array}{l}0.026 \\
(0.057)\end{array}$ & $\begin{array}{l}0.027 \\
(0.057)\end{array}$ & $\begin{array}{l}0.030 \\
(0.057)\end{array}$ \\
\hline Low childhood SES & $\begin{array}{l}-0.113 \\
(0.067)\end{array}$ & $\begin{array}{l}-0.190^{*} \\
(0.060)\end{array}$ & $\begin{array}{l}-0.207^{*} \\
(0.059)\end{array}$ & $\begin{array}{l}-0.212^{*} \\
(0.062)\end{array}$ & $\begin{array}{l}-0.211^{*} \\
(0.064)\end{array}$ & $\begin{array}{l}-0.214^{*} \\
(0.064)\end{array}$ & $\begin{array}{l}-0.215^{*} \\
(0.063)\end{array}$ & $\begin{array}{l}-0.204^{*} \\
(0.062)\end{array}$ & $\begin{array}{l}-0.199 * \\
(0.061)\end{array}$ \\
\hline Medium childhood SES & $\begin{array}{l}0.002 \\
(0.055)\end{array}$ & $\begin{array}{l}-0.071 \\
(0.051)\end{array}$ & $\begin{array}{l}-0.108 * \\
(0.049)\end{array}$ & $\begin{array}{l}-0.125^{*} \\
(0.051)\end{array}$ & $\begin{array}{l}-0.129 * \\
(0.052)\end{array}$ & $\begin{array}{l}-0.131 * \\
(0.053)\end{array}$ & $\begin{array}{l}-0.130 * \\
(0.052)\end{array}$ & $\begin{array}{l}-0.124^{*} \\
(0.051)\end{array}$ & $\begin{array}{l}-0.125^{*} \\
(0.050)\end{array}$ \\
\hline R-squared & 0.176 & 0.153 & 0.142 & 0.115 & 0.094 & 0.076 & 0.067 & 0.062 & 0.061 \\
\hline Observations & 1009 & 1035 & 1038 & 1039 & 1039 & 1039 & 1039 & 1039 & 1039 \\
\hline
\end{tabular}


Table A.XIII Continued (Women) ${ }^{\mathrm{a}}$

\begin{tabular}{|c|c|c|c|c|c|c|c|c|c|}
\hline Nordic & $\begin{array}{l}\leq 25 \\
(1)\end{array}$ & $\begin{array}{l}\leq 30 \\
(2)\end{array}$ & $\begin{array}{l}\leq 35 \\
(3)\end{array}$ & $\begin{array}{l}\leq 40 \\
(4)\end{array}$ & $\begin{array}{l}\leq 45 \\
(5)\end{array}$ & $\begin{array}{l}\leq 50 \\
(6)\end{array}$ & $\begin{array}{l}\leq 55 \\
(7)\end{array}$ & $\begin{array}{l}\leq 60 \\
(8)\end{array}$ & $\begin{array}{l}\leq 65 \\
(9)\end{array}$ \\
\hline Low childhood HI & $\begin{array}{l}-0.029 \\
(0.068)\end{array}$ & $\begin{array}{l}-0.064 \\
(0.061)\end{array}$ & $\begin{array}{l}-0.061 \\
(0.054)\end{array}$ & $\begin{array}{l}-0.046 \\
(0.052)\end{array}$ & $\begin{array}{l}-0.041 \\
(0.050)\end{array}$ & $\begin{array}{l}-0.043 \\
(0.049)\end{array}$ & $\begin{array}{l}-0.037 \\
(0.047)\end{array}$ & $\begin{array}{l}-0.031 \\
(0.045)\end{array}$ & $\begin{array}{l}-0.033 \\
(0.044)\end{array}$ \\
\hline Medium childhood HI & $\begin{array}{l}-0.038 \\
(0.068)\end{array}$ & $\begin{array}{l}-0.054 \\
(0.059)\end{array}$ & $\begin{array}{l}-0.065 \\
(0.053)\end{array}$ & $\begin{array}{l}-0.058 \\
(0.050)\end{array}$ & $\begin{array}{l}-0.069 \\
(0.048)\end{array}$ & $\begin{array}{l}-0.068 \\
(0.047)\end{array}$ & $\begin{array}{l}-0.070 \\
(0.045)\end{array}$ & $\begin{array}{l}-0.065 \\
(0.043)\end{array}$ & $\begin{array}{l}-0.064 \\
(0.042)\end{array}$ \\
\hline Low childhood SES & $\begin{array}{l}-0.199 * \\
(0.071)\end{array}$ & $\begin{array}{l}-0.236^{*} \\
(0.062)\end{array}$ & $\begin{array}{l}-0.234 * \\
(0.055)\end{array}$ & $\begin{array}{l}-0.231 * \\
(0.053)\end{array}$ & $\begin{array}{l}-0.221 * \\
(0.051)\end{array}$ & $\begin{array}{l}-0.219 * \\
(0.050)\end{array}$ & $\begin{array}{l}-0.216^{*} \\
(0.048)\end{array}$ & $\begin{array}{l}-0.214^{*} \\
(0.047)\end{array}$ & $\begin{array}{l}-0.214^{*} \\
(0.046)\end{array}$ \\
\hline Medium childhood SES & $\begin{array}{l}0.031 \\
(0.072)\end{array}$ & $\begin{array}{l}-0.032 \\
(0.062)\end{array}$ & $\begin{array}{l}-0.056 \\
(0.055)\end{array}$ & $\begin{array}{l}-0.063 \\
(0.051)\end{array}$ & $\begin{array}{l}-0.073 \\
(0.050)\end{array}$ & $\begin{array}{l}-0.068 \\
(0.048)\end{array}$ & $\begin{array}{l}-0.072 \\
(0.046)\end{array}$ & $\begin{array}{l}-0.075 \\
(0.044)\end{array}$ & $\begin{array}{l}-0.077 \\
(0.042)\end{array}$ \\
\hline $\begin{array}{l}\text { R-squared } \\
\text { Observations }\end{array}$ & $\begin{array}{l}0.039 \\
1312\end{array}$ & $\begin{array}{l}0.041 \\
1405\end{array}$ & $\begin{array}{l}0.047 \\
1427\end{array}$ & $\begin{array}{l}0.045 \\
1444\end{array}$ & $\begin{array}{l}0.040 \\
1462\end{array}$ & $\begin{array}{l}0.038 \\
1468\end{array}$ & $\begin{array}{l}0.040 \\
1469\end{array}$ & $\begin{array}{l}0.043 \\
1469\end{array}$ & $\begin{array}{l}0.044 \\
1469\end{array}$ \\
\hline Continental & $(1)$ & $(2)$ & (3) & (4) & $(5)$ & $(6)$ & $(7)$ & $(8)$ & (9) \\
\hline Low childhood HI & $\begin{array}{l}-0.069^{*} \\
(0.034)\end{array}$ & $\begin{array}{l}-0.050 \\
(0.032)\end{array}$ & $\begin{array}{l}-0.052 \\
(0.031)\end{array}$ & $\begin{array}{l}-0.051 \\
(0.030)\end{array}$ & $\begin{array}{l}-0.052 \\
(0.029)\end{array}$ & $\begin{array}{l}-0.049 \\
(0.029)\end{array}$ & $\begin{array}{l}-0.043 \\
(0.028)\end{array}$ & $\begin{array}{l}-0.043 \\
(0.028)\end{array}$ & $\begin{array}{l}-0.043 \\
(0.028)\end{array}$ \\
\hline Medium childhood HI & $\begin{array}{l}-0.052 \\
(0.035)\end{array}$ & $\begin{array}{l}-0.053 \\
(0.034)\end{array}$ & $\begin{array}{l}-0.064 \\
(0.034)\end{array}$ & $\begin{array}{l}-0.068^{*} \\
(0.033)\end{array}$ & $\begin{array}{l}-0.072 * \\
(0.032)\end{array}$ & $\begin{array}{l}-0.070^{*} \\
(0.032)\end{array}$ & $\begin{array}{l}-0.066^{*} \\
(0.031)\end{array}$ & $\begin{array}{l}-0.064^{*} \\
(0.031)\end{array}$ & $\begin{array}{l}-0.063 * \\
(0.031)\end{array}$ \\
\hline Low childhood SES & $\begin{array}{l}-0.423^{*} \\
(0.036)\end{array}$ & $\begin{array}{l}-0.411^{*} \\
(0.034)\end{array}$ & $\begin{array}{l}-0.406^{*} \\
(0.033)\end{array}$ & $\begin{array}{l}-0.392 * \\
(0.032)\end{array}$ & $\begin{array}{l}-0.382^{*} \\
(0.032)\end{array}$ & $\begin{array}{l}-0.376^{*} \\
(0.031)\end{array}$ & $\begin{array}{l}-0.373 * \\
(0.031)\end{array}$ & $\begin{array}{l}-0.368^{*} \\
(0.031)\end{array}$ & $\begin{array}{l}-0.365^{*} \\
(0.031)\end{array}$ \\
\hline Medium childhood SES & $\begin{array}{l}-0.199 * \\
(0.031)\end{array}$ & $\begin{array}{l}-0.200^{*} \\
(0.030)\end{array}$ & $\begin{array}{l}-0.194 * \\
(0.029)\end{array}$ & $\begin{array}{l}-0.188^{*} \\
(0.028)\end{array}$ & $\begin{array}{l}-0.187^{*} \\
(0.028)\end{array}$ & $\begin{array}{l}-0.186^{*} \\
(0.027)\end{array}$ & $\begin{array}{l}-0.186^{*} \\
(0.027)\end{array}$ & $\begin{array}{l}-0.183^{*} \\
(0.027)\end{array}$ & $\begin{array}{l}-0.181 * \\
(0.027)\end{array}$ \\
\hline $\begin{array}{l}\text { R-squared } \\
\text { Observations }\end{array}$ & $\begin{array}{l}0.239 \\
3046\end{array}$ & $\begin{array}{l}0.228 \\
3134\end{array}$ & $\begin{array}{l}0.221 \\
3165\end{array}$ & $\begin{array}{l}0.216 \\
3191\end{array}$ & $\begin{array}{l}0.213 \\
3203\end{array}$ & $\begin{array}{l}0.209 \\
3207\end{array}$ & $\begin{array}{l}0.204 \\
3209\end{array}$ & $\begin{array}{l}0.200 \\
3209\end{array}$ & $\begin{array}{l}0.197 \\
3209\end{array}$ \\
\hline Mediterranean & (1) & (2) & (3) & (4) & $(5)$ & (6) & (7) & $(8)$ & (9) \\
\hline Low childhood HI & $\begin{array}{l}-0.119 \\
(0.084)\end{array}$ & $\begin{array}{l}-0.207^{*} \\
(0.077)\end{array}$ & $\begin{array}{l}-0.159 * \\
(0.072)\end{array}$ & $\begin{array}{l}-0.134 \\
(0.070)\end{array}$ & $\begin{array}{l}-0.139 * \\
(0.066)\end{array}$ & $\begin{array}{l}-0.142 * \\
(0.063)\end{array}$ & $\begin{array}{l}-0.135^{*} \\
(0.062)\end{array}$ & $\begin{array}{l}-0.130 * \\
(0.061)\end{array}$ & $\begin{array}{l}-0.130 * \\
(0.060)\end{array}$ \\
\hline Medium childhood HI & $\begin{array}{l}0.050 \\
(0.090)\end{array}$ & $\begin{array}{l}-0.044 \\
(0.080)\end{array}$ & $\begin{array}{l}-0.018 \\
(0.076)\end{array}$ & $\begin{array}{l}-0.019 \\
(0.074)\end{array}$ & $\begin{array}{l}-0.035 \\
(0.070)\end{array}$ & $\begin{array}{l}-0.032 \\
(0.067)\end{array}$ & $\begin{array}{l}-0.036 \\
(0.066)\end{array}$ & $\begin{array}{l}-0.035 \\
(0.065)\end{array}$ & $\begin{array}{l}-0.034 \\
(0.064)\end{array}$ \\
\hline Low childhood SES & $\begin{array}{l}-0.227^{*} \\
(0.089)\end{array}$ & $\begin{array}{l}-0.209^{*} \\
(0.082)\end{array}$ & $\begin{array}{l}-0.233^{*} \\
(0.078)\end{array}$ & $\begin{array}{l}-0.217^{*} \\
(0.077)\end{array}$ & $\begin{array}{l}-0.225^{*} \\
(0.072)\end{array}$ & $\begin{array}{l}-0.256^{*} \\
(0.069)\end{array}$ & $\begin{array}{l}-0.264 * \\
(0.068)\end{array}$ & $\begin{array}{l}-0.264 * \\
(0.067)\end{array}$ & $\begin{array}{l}-0.264 * \\
(0.067)\end{array}$ \\
\hline Medium childhood SES & $\begin{array}{l}-0.050 \\
(0.084)\end{array}$ & $\begin{array}{l}-0.054 \\
(0.077)\end{array}$ & $\begin{array}{l}-0.080 \\
(0.073)\end{array}$ & $\begin{array}{l}-0.051 \\
(0.070)\end{array}$ & $\begin{array}{l}-0.090 \\
(0.065)\end{array}$ & $\begin{array}{l}-0.105 \\
(0.062)\end{array}$ & $\begin{array}{l}-0.113 \\
(0.061)\end{array}$ & $\begin{array}{l}-0.110 \\
(0.060)\end{array}$ & $\begin{array}{l}-0.109 \\
(0.059)\end{array}$ \\
\hline R-squared & 0.174 & 0.168 & 0.161 & 0.145 & 0.143 & 0.134 & 0.130 & 0.128 & 0.128 \\
\hline Observations & 969 & 1089 & 1146 & 1189 & 1218 & 1239 & 1243 & 1245 & 1246 \\
\hline Transitional & (1) & $(2)$ & (3) & (4) & $(5)$ & (6) & (7) & $(8)$ & (9) \\
\hline Low childhood HI & $\begin{array}{l}0.021 \\
(0.054)\end{array}$ & $\begin{array}{l}0.051 \\
(0.053)\end{array}$ & $\begin{array}{l}0.090 \\
(0.053)\end{array}$ & $\begin{array}{l}0.087 \\
(0.055)\end{array}$ & $\begin{array}{l}0.073 \\
(0.059)\end{array}$ & $\begin{array}{l}0.073 \\
(0.059)\end{array}$ & $\begin{array}{l}0.072 \\
(0.059)\end{array}$ & $\begin{array}{l}0.069 \\
(0.059)\end{array}$ & $\begin{array}{l}0.065 \\
(0.058)\end{array}$ \\
\hline Medium childhood HI & $\begin{array}{l}0.031 \\
(0.054)\end{array}$ & $\begin{array}{l}0.026 \\
(0.052)\end{array}$ & $\begin{array}{l}0.060 \\
(0.048)\end{array}$ & $\begin{array}{l}0.072 \\
(0.050)\end{array}$ & $\begin{array}{l}0.073 \\
(0.055)\end{array}$ & $\begin{array}{l}0.070 \\
(0.056)\end{array}$ & $\begin{array}{l}0.061 \\
(0.055)\end{array}$ & $\begin{array}{l}0.059 \\
(0.055)\end{array}$ & $\begin{array}{l}0.057 \\
(0.054)\end{array}$ \\
\hline Low childhood SES & $\begin{array}{l}-0.298 * \\
(0.068)\end{array}$ & $\begin{array}{l}-0.312^{*} \\
(0.067)\end{array}$ & $\begin{array}{l}-0.325^{*} \\
(0.059)\end{array}$ & $\begin{array}{c}-0.294 * \\
(0.063)\end{array}$ & $\begin{array}{l}-0.294 * \\
(0.063)\end{array}$ & $\begin{array}{l}-0.283^{*} \\
(0.063)\end{array}$ & $\begin{array}{l}-0.270 * \\
(0.062)\end{array}$ & $\begin{array}{l}-0.268^{*} \\
(0.062)\end{array}$ & $\begin{array}{l}-0.268 * \\
(0.061)\end{array}$ \\
\hline Medium childhood SES & $\begin{array}{l}-0.125^{*} \\
(0.052)\end{array}$ & $\begin{array}{l}-0.111 * \\
(0.051)\end{array}$ & $\begin{array}{l}-0.121 * \\
(0.046)\end{array}$ & $\begin{array}{l}-0.101^{*} \\
(0.047)\end{array}$ & $\begin{array}{l}-0.084 \\
(0.047)\end{array}$ & $\begin{array}{l}-0.081 \\
(0.047)\end{array}$ & $\begin{array}{l}-0.072 \\
(0.046)\end{array}$ & $\begin{array}{l}-0.070 \\
(0.046)\end{array}$ & $\begin{array}{l}-0.068 \\
(0.045)\end{array}$ \\
\hline R-squared & 0.206 & 0.199 & 0.194 & 0.156 & 0.126 & 0.106 & 0.098 & 0.096 & 0.096 \\
\hline Observations & 1178 & 1221 & 1234 & 1239 & 1245 & 1246 & 1246 & 1246 & 1246 \\
\hline
\end{tabular}


Table A.XIV Log working years regressions over the life cycle in Nordic, Continental, Mediterranean and Transitional countries (Men) ${ }^{\mathrm{a}}$

\begin{tabular}{|c|c|c|c|c|c|c|c|c|c|}
\hline Nordic & $\begin{array}{l}\leq 25 \\
(1)\end{array}$ & $\begin{array}{l}\leq 30 \\
(2) \\
\end{array}$ & $\begin{array}{l}\leq 35 \\
(3)\end{array}$ & $\begin{array}{l}\leq 40 \\
(4)\end{array}$ & $\begin{array}{l}\leq 45 \\
(5) \\
\end{array}$ & $\begin{array}{l}\leq 50 \\
(6) \\
\end{array}$ & $\begin{array}{l}\leq 55 \\
(7)\end{array}$ & $\begin{array}{l}\leq 60 \\
(8) \\
\end{array}$ & $\begin{array}{l}\leq 65 \\
(9)\end{array}$ \\
\hline \multirow[t]{2}{*}{ Low childhood HI } & -0.014 & $-0.091 *$ & -0.037 & -0.036 & -0.026 & -0.020 & -0.017 & -0.017 & -0.017 \\
\hline & $(0.045)$ & $(0.037)$ & $(0.023)$ & $(0.020)$ & $(0.014)$ & $(0.012)$ & $(0.011)$ & $(0.011)$ & $(0.011)$ \\
\hline \multirow[t]{2}{*}{ Medium childhood HI } & -0.009 & -0.034 & -0.026 & -0.022 & -0.025 & -0.016 & -0.017 & -0.019 & -0.022 \\
\hline & $(0.040)$ & $(0.031)$ & $(0.022)$ & $(0.017)$ & $(0.015)$ & $(0.012)$ & $(0.011)$ & $(0.011)$ & $(0.012)$ \\
\hline \multirow[t]{2}{*}{ Low childhood SES } & $0.477 *$ & $0.419^{*}$ & $0.276^{*}$ & $0.201 *$ & $0.164^{*}$ & $0.124 *$ & $0.104^{*}$ & $0.082 *$ & $0.065^{*}$ \\
\hline & $(0.048)$ & $(0.039)$ & $(0.026)$ & $(0.020)$ & $(0.018)$ & $(0.015)$ & $(0.014)$ & $(0.013)$ & $(0.014)$ \\
\hline \multirow[t]{2}{*}{ Medium childhood SES } & $0.254 *$ & $0.301 *$ & $0.197^{*}$ & $0.140 *$ & $0.112^{*}$ & $0.086^{*}$ & $0.073 *$ & $0.061 *$ & $0.051 *$ \\
\hline & $(0.047)$ & $(0.036)$ & $(0.024)$ & $(0.020)$ & $(0.016)$ & $(0.012)$ & $(0.011)$ & $(0.011)$ & $(0.012)$ \\
\hline R-squared & 0.154 & 0.152 & 0.140 & 0.118 & 0.118 & 0.103 & 0.096 & 0.082 & 0.074 \\
\hline Observations & 1181 & 1336 & 1360 & 1366 & 1367 & 1368 & 1368 & 1368 & 1368 \\
\hline Continental & $(1)$ & (2) & (3) & $(4)$ & $(5)$ & (6) & $(7)$ & $(8)$ & (9) \\
\hline \multirow[t]{2}{*}{ Low childhood HI } & -0.025 & -0.005 & -0.015 & -0.011 & -0.009 & -0.009 & -0.009 & -0.012 & -0.012 \\
\hline & $(0.024)$ & $(0.018)$ & $(0.013)$ & $(0.009)$ & $(0.008)$ & $(0.007)$ & $(0.007)$ & $(0.007)$ & $(0.007)$ \\
\hline \multirow[t]{2}{*}{ Medium childhood HI } & -0.019 & 0.005 & 0.002 & -0.005 & -0.005 & -0.005 & -0.006 & -0.007 & -0.007 \\
\hline & $(0.025)$ & $(0.019)$ & $(0.013)$ & $(0.010)$ & $(0.008)$ & $(0.008)$ & $(0.007)$ & $(0.008)$ & $(0.008)$ \\
\hline \multirow[t]{2}{*}{ Low childhood SES } & $0.441 *$ & $0.371^{*}$ & $0.238^{*}$ & $0.175^{*}$ & $0.137 *$ & $0.110^{*}$ & $0.089^{*}$ & $0.066^{*}$ & $0.050^{*}$ \\
\hline & $(0.027)$ & $(0.020)$ & $(0.013)$ & $(0.010)$ & $(0.008)$ & $(0.008)$ & $(0.008)$ & $(0.008)$ & $(0.008)$ \\
\hline \multirow[t]{2}{*}{ Medium childhood SES } & $0.289 *$ & $0.248^{*}$ & $0.157^{*}$ & $0.113 *$ & $0.092 *$ & $0.078^{*}$ & $0.069 *$ & $0.060^{*}$ & $0.052 *$ \\
\hline & $(0.027)$ & $(0.021)$ & $(0.014)$ & $(0.010)$ & $(0.008)$ & $(0.007)$ & $(0.007)$ & $(0.007)$ & $(0.008)$ \\
\hline R-squared & 0.141 & 0.145 & 0.142 & 0.132 & 0.130 & 0.115 & 0.089 & 0.057 & 0.050 \\
\hline Observations & 3184 & 3455 & 3480 & 3486 & 3486 & 3486 & 3486 & 3486 & 3486 \\
\hline Mediterranean & $(1)$ & $(2)$ & (3) & (4) & $(5)$ & (6) & $(7)$ & $(8)$ & (9) \\
\hline \multirow[t]{2}{*}{ Low childhood $\mathrm{HI}$} & 0.029 & 0.008 & -0.013 & -0.003 & 0.000 & -0.000 & -0.004 & -0.023 & -0.024 \\
\hline & $(0.036)$ & $(0.029)$ & $(0.022)$ & $(0.016)$ & $(0.014)$ & $(0.013)$ & $(0.013)$ & $(0.017)$ & $(0.016)$ \\
\hline \multirow[t]{2}{*}{ Medium childhood HI } & -0.019 & -0.028 & -0.027 & -0.022 & -0.020 & -0.012 & -0.008 & -0.005 & -0.003 \\
\hline & $(0.038)$ & $(0.029)$ & $(0.020)$ & $(0.016)$ & $(0.014)$ & $(0.012)$ & $(0.011)$ & $(0.012)$ & $(0.012)$ \\
\hline \multirow[t]{2}{*}{ Low childhood SES } & $0.390 *$ & $0.318^{*}$ & $0.192 *$ & $0.142 *$ & $0.108 *$ & $0.093 *$ & $0.074 *$ & $0.057 *$ & $0.046^{*}$ \\
\hline & $(0.040)$ & $(0.031)$ & $(0.021)$ & $(0.015)$ & $(0.013)$ & $(0.012)$ & $(0.012)$ & $(0.012)$ & $(0.013)$ \\
\hline \multirow[t]{2}{*}{ Medium childhood SES } & $0.255^{*}$ & $0.241^{*}$ & $0.157^{*}$ & $0.107^{*}$ & $0.081^{*}$ & $0.070^{*}$ & $0.056^{*}$ & $0.038^{*}$ & $0.036^{*}$ \\
\hline & $(0.041)$ & $(0.030)$ & $(0.020)$ & $(0.016)$ & $(0.013)$ & $(0.012)$ & $(0.012)$ & $(0.015)$ & $(0.014)$ \\
\hline R-squared & 0.159 & 0.150 & 0.141 & 0.128 & 0.107 & 0.095 & 0.070 & 0.053 & 0.060 \\
\hline Observations & 1686 & 1867 & 1894 & 1902 & 1906 & 1907 & 1907 & 1910 & 1910 \\
\hline Transitional & (1) & (2) & (3) & (4) & (5) & (6) & $(7)$ & $(8)$ & (9) \\
\hline \multirow[t]{2}{*}{ Low childhood HI } & -0.000 & -0.011 & 0.007 & 0.006 & 0.009 & 0.014 & 0.010 & 0.004 & 0.002 \\
\hline & $(0.037)$ & $(0.023)$ & $(0.018)$ & $(0.015)$ & $(0.015)$ & $(0.016)$ & $(0.018)$ & $(0.019)$ & $(0.020)$ \\
\hline \multirow[t]{2}{*}{ Medium childhood HI } & 0.025 & 0.006 & 0.021 & 0.018 & 0.025 & $0.031 *$ & $0.034 *$ & $0.036^{*}$ & 0.033 \\
\hline & $(0.035)$ & $(0.024)$ & $(0.018)$ & $(0.015)$ & $(0.014)$ & $(0.015)$ & $(0.016)$ & $(0.018)$ & $(0.019)$ \\
\hline \multirow[t]{2}{*}{ Low childhood SES } & $0.195 *$ & $0.121^{*}$ & $0.066^{*}$ & $0.050 *$ & 0.029 & 0.013 & 0.001 & -0.010 & -0.020 \\
\hline & $(0.041)$ & $(0.030)$ & $(0.020)$ & $(0.018)$ & $(0.016)$ & $(0.016)$ & $(0.018)$ & $(0.019)$ & $(0.020)$ \\
\hline \multirow[t]{2}{*}{ Medium childhood SES } & $0.192 *$ & $0.125^{*}$ & $0.085^{*}$ & $0.071 *$ & $0.052^{*}$ & $0.036^{*}$ & 0.026 & 0.017 & 0.011 \\
\hline & $(0.038)$ & $(0.024)$ & $(0.015)$ & $(0.014)$ & $(0.012)$ & $(0.013)$ & $(0.014)$ & $(0.015)$ & $(0.016)$ \\
\hline R-squared & 0.060 & 0.073 & 0.090 & 0.075 & 0.073 & 0.077 & 0.092 & 0.114 & 0.106 \\
\hline Observations & 1009 & 1035 & 1038 & 1039 & 1039 & 1039 & 1039 & 1039 & 1039 \\
\hline
\end{tabular}


Table A.XIV Continued (Women) ${ }^{\mathrm{a}}$

\begin{tabular}{|c|c|c|c|c|c|c|c|c|c|}
\hline Nordic & $\begin{array}{l}\leq 25 \\
(1)\end{array}$ & $\begin{array}{l}\leq 30 \\
(2)\end{array}$ & $\begin{array}{l}\leq 35 \\
(3)\end{array}$ & $\begin{array}{l}\leq 40 \\
(4)\end{array}$ & $\begin{array}{l}\leq 45 \\
(5)\end{array}$ & $\begin{array}{l}\leq 50 \\
(6)\end{array}$ & $\begin{array}{l}\leq 55 \\
(7)\end{array}$ & $\begin{array}{l}\leq 60 \\
(8)\end{array}$ & $\begin{array}{l}\leq 65 \\
(9)\end{array}$ \\
\hline Low childhood $\mathrm{HI}$ & $\begin{array}{l}-0.027 \\
(0.039)\end{array}$ & $\begin{array}{l}-0.039 \\
(0.034)\end{array}$ & $\begin{array}{l}-0.007 \\
(0.031)\end{array}$ & $\begin{array}{l}-0.021 \\
(0.030)\end{array}$ & $\begin{array}{l}-0.008 \\
(0.029)\end{array}$ & $\begin{array}{l}-0.023 \\
(0.029)\end{array}$ & $\begin{array}{l}-0.025 \\
(0.026)\end{array}$ & $\begin{array}{l}-0.032 \\
(0.025)\end{array}$ & $\begin{array}{l}-0.035 \\
(0.025)\end{array}$ \\
\hline Medium childhood HI & $\begin{array}{l}0.030 \\
(0.036)\end{array}$ & $\begin{array}{l}0.008 \\
(0.031)\end{array}$ & $\begin{array}{l}0.001 \\
(0.030)\end{array}$ & $\begin{array}{l}-0.019 \\
(0.028)\end{array}$ & $\begin{array}{l}-0.030 \\
(0.030)\end{array}$ & $\begin{array}{l}-0.021 \\
(0.028)\end{array}$ & $\begin{array}{l}-0.036 \\
(0.026)\end{array}$ & $\begin{array}{l}-0.044 \\
(0.025)\end{array}$ & $\begin{array}{l}-0.048 \\
(0.026)\end{array}$ \\
\hline Low childhood SES & $\begin{array}{l}0.429 * \\
(0.040)\end{array}$ & $\begin{array}{l}0.275^{*} \\
(0.033)\end{array}$ & $\begin{array}{l}0.164^{*} \\
(0.032)\end{array}$ & $\begin{array}{l}0.128 * \\
(0.031)\end{array}$ & $\begin{array}{l}0.092 * \\
(0.029)\end{array}$ & $\begin{array}{l}0.042 \\
(0.029)\end{array}$ & $\begin{array}{l}0.020 \\
(0.028)\end{array}$ & $\begin{array}{l}-0.004 \\
(0.027)\end{array}$ & $\begin{array}{l}-0.020 \\
(0.028)\end{array}$ \\
\hline Medium childhood SES & $\begin{array}{l}0.259 * \\
(0.041)\end{array}$ & $\begin{array}{l}0.142 * \\
(0.035)\end{array}$ & $\begin{array}{l}0.066^{*} \\
(0.031)\end{array}$ & $\begin{array}{l}0.045 \\
(0.029)\end{array}$ & $\begin{array}{l}0.009 \\
(0.030)\end{array}$ & $\begin{array}{l}-0.007 \\
(0.027)\end{array}$ & $\begin{array}{l}-0.005 \\
(0.025)\end{array}$ & $\begin{array}{l}-0.011 \\
(0.024)\end{array}$ & $\begin{array}{l}-0.023 \\
(0.025)\end{array}$ \\
\hline $\begin{array}{l}\text { R-squared } \\
\text { Observations }\end{array}$ & $\begin{array}{l}0.140 \\
1312\end{array}$ & $\begin{array}{l}0.078 \\
1405\end{array}$ & $\begin{array}{l}0.040 \\
1427\end{array}$ & $\begin{array}{l}0.046 \\
1444\end{array}$ & $\begin{array}{l}0.048 \\
1462\end{array}$ & $\begin{array}{l}0.049 \\
1468\end{array}$ & $\begin{array}{l}0.047 \\
1469\end{array}$ & $\begin{array}{l}0.048 \\
1469\end{array}$ & $\begin{array}{l}0.052 \\
1469\end{array}$ \\
\hline Continental & $(1)$ & $(2)$ & (3) & $(4)$ & $(5)$ & $(6)$ & $(7)$ & $(8)$ & $(9)$ \\
\hline Low childhood $\mathrm{HI}$ & $\begin{array}{l}-0.017 \\
(0.020)\end{array}$ & $\begin{array}{l}-0.020 \\
(0.020)\end{array}$ & $\begin{array}{l}-0.040 \\
(0.021)\end{array}$ & $\begin{array}{l}-0.024 \\
(0.021)\end{array}$ & $\begin{array}{l}-0.026 \\
(0.021)\end{array}$ & $\begin{array}{l}-0.028 \\
(0.021)\end{array}$ & $\begin{array}{l}-0.024 \\
(0.021)\end{array}$ & $\begin{array}{l}-0.023 \\
(0.022)\end{array}$ & $\begin{array}{l}-0.024 \\
(0.022)\end{array}$ \\
\hline Medium childhood HI & $\begin{array}{l}0.026 \\
(0.022)\end{array}$ & $\begin{array}{l}0.024 \\
(0.022)\end{array}$ & $\begin{array}{l}0.010 \\
(0.022)\end{array}$ & $\begin{array}{l}0.005 \\
(0.024)\end{array}$ & $\begin{array}{l}-0.000 \\
(0.024)\end{array}$ & $\begin{array}{l}-0.004 \\
(0.024)\end{array}$ & $\begin{array}{l}0.001 \\
(0.024)\end{array}$ & $\begin{array}{l}0.002 \\
(0.025)\end{array}$ & $\begin{array}{l}0.003 \\
(0.025)\end{array}$ \\
\hline Low childhood SES & $\begin{array}{l}0.271^{*} \\
(0.023)\end{array}$ & $\begin{array}{l}0.123^{*} \\
(0.022)\end{array}$ & $\begin{array}{l}0.045 \\
(0.023)\end{array}$ & $\begin{array}{l}0.018 \\
(0.024)\end{array}$ & $\begin{array}{l}-0.011 \\
(0.024)\end{array}$ & $\begin{array}{l}-0.045 \\
(0.024)\end{array}$ & $\begin{array}{l}-0.066^{*} \\
(0.025)\end{array}$ & $\begin{array}{l}-0.087^{*} \\
(0.025)\end{array}$ & $\begin{array}{l}-0.098 * \\
(0.025)\end{array}$ \\
\hline Medium childhood SES & $\begin{array}{l}0.193 * \\
(0.023)\end{array}$ & $\begin{array}{l}0.096^{*} \\
(0.021)\end{array}$ & $\begin{array}{l}0.048^{*} \\
(0.022)\end{array}$ & $\begin{array}{l}0.033 \\
(0.022)\end{array}$ & $\begin{array}{l}0.005 \\
(0.023)\end{array}$ & $\begin{array}{l}-0.006 \\
(0.022)\end{array}$ & $\begin{array}{l}-0.013 \\
(0.022)\end{array}$ & $\begin{array}{l}-0.025 \\
(0.023)\end{array}$ & $\begin{array}{l}-0.031 \\
(0.023)\end{array}$ \\
\hline $\begin{array}{l}\text { R-squared } \\
\text { Observations }\end{array}$ & $\begin{array}{l}0.095 \\
3046\end{array}$ & $\begin{array}{l}0.040 \\
3134\end{array}$ & $\begin{array}{l}0.055 \\
3165\end{array}$ & $\begin{array}{l}0.073 \\
3191\end{array}$ & $\begin{array}{l}0.085 \\
3203\end{array}$ & $\begin{array}{l}0.100 \\
3207\end{array}$ & $\begin{array}{l}0.107 \\
3209\end{array}$ & $\begin{array}{l}0.107 \\
3209\end{array}$ & $\begin{array}{l}0.102 \\
3209\end{array}$ \\
\hline Mediterranean & (1) & $(2)$ & (3) & (4) & (5) & (6) & (7) & $(8)$ & (9) \\
\hline Low childhood $\mathrm{HI}$ & $\begin{array}{l}0.021 \\
(0.045)\end{array}$ & $\begin{array}{l}0.059 \\
(0.050)\end{array}$ & $\begin{array}{l}-0.025 \\
(0.043)\end{array}$ & $\begin{array}{l}-0.003 \\
(0.045)\end{array}$ & $\begin{array}{l}-0.073 \\
(0.041)\end{array}$ & $\begin{array}{l}-0.097 * \\
(0.041)\end{array}$ & $\begin{array}{l}-0.103 * \\
(0.041)\end{array}$ & $\begin{array}{l}-0.116^{*} \\
(0.043)\end{array}$ & $\begin{array}{l}-0.105 * \\
(0.042)\end{array}$ \\
\hline Medium childhood HI & $\begin{array}{l}-0.034 \\
(0.051)\end{array}$ & $\begin{array}{l}0.061 \\
(0.049)\end{array}$ & $\begin{array}{l}-0.051 \\
(0.046)\end{array}$ & $\begin{array}{l}-0.004 \\
(0.047)\end{array}$ & $\begin{array}{l}-0.099 * \\
(0.044)\end{array}$ & $\begin{array}{l}-0.102 * \\
(0.042)\end{array}$ & $\begin{array}{l}-0.095 * \\
(0.040)\end{array}$ & $\begin{array}{l}-0.105^{*} \\
(0.041)\end{array}$ & $\begin{array}{l}-0.096^{*} \\
(0.042)\end{array}$ \\
\hline Low childhood SES & $\begin{array}{l}0.411^{*} \\
(0.050)\end{array}$ & $\begin{array}{l}0.135^{*} \\
(0.047)\end{array}$ & $\begin{array}{l}0.022 \\
(0.044)\end{array}$ & $\begin{array}{l}-0.073 \\
(0.047)\end{array}$ & $\begin{array}{l}-0.104 * \\
(0.044)\end{array}$ & $\begin{array}{l}-0.148^{*} \\
(0.043)\end{array}$ & $\begin{array}{l}-0.165^{*} \\
(0.042)\end{array}$ & $\begin{array}{l}-0.195 * \\
(0.043)\end{array}$ & $\begin{array}{l}-0.201 * \\
(0.043)\end{array}$ \\
\hline Medium childhood SES & $\begin{array}{l}0.281^{*} \\
(0.048)\end{array}$ & $\begin{array}{l}0.029 \\
(0.047)\end{array}$ & $\begin{array}{l}0.002 \\
(0.043)\end{array}$ & $\begin{array}{l}-0.016 \\
(0.042)\end{array}$ & $\begin{array}{l}-0.021 \\
(0.042)\end{array}$ & $\begin{array}{l}-0.062 \\
(0.041)\end{array}$ & $\begin{array}{l}-0.066 \\
(0.039)\end{array}$ & $\begin{array}{l}-0.068 \\
(0.040)\end{array}$ & $\begin{array}{l}-0.075 \\
(0.041)\end{array}$ \\
\hline R-squared & 0.157 & 0.051 & 0.025 & 0.036 & 0.056 & 0.064 & 0.076 & 0.088 & 0.086 \\
\hline Observations & 969 & 1089 & 1146 & 1189 & 1218 & 1239 & 1243 & 1245 & 1246 \\
\hline Transitional & (1) & (2) & (3) & (4) & $(5)$ & (6) & (7) & $(8)$ & (9) \\
\hline Low childhood HI & $\begin{array}{l}-0.016 \\
(0.030)\end{array}$ & $\begin{array}{l}-0.066^{*} \\
(0.025)\end{array}$ & $\begin{array}{l}-0.046 \\
(0.024)\end{array}$ & $\begin{array}{l}-0.056^{*} \\
(0.021)\end{array}$ & $\begin{array}{l}-0.063 * \\
(0.021)\end{array}$ & $\begin{array}{l}-0.042 * \\
(0.020)\end{array}$ & $\begin{array}{l}-0.046^{*} \\
(0.021)\end{array}$ & $\begin{array}{l}-0.050^{*} \\
(0.021)\end{array}$ & $\begin{array}{l}-0.050^{*} \\
(0.021)\end{array}$ \\
\hline Medium childhood HI & $\begin{array}{l}-0.037 \\
(0.032)\end{array}$ & $\begin{array}{l}-0.114^{*} \\
(0.030)\end{array}$ & $\begin{array}{l}-0.063 * \\
(0.026)\end{array}$ & $\begin{array}{l}-0.063 * \\
(0.023)\end{array}$ & $\begin{array}{l}-0.054 * \\
(0.021)\end{array}$ & $\begin{array}{l}-0.027 \\
(0.021)\end{array}$ & $\begin{array}{l}-0.018 \\
(0.021)\end{array}$ & $\begin{array}{l}-0.018 \\
(0.022)\end{array}$ & $\begin{array}{l}-0.018 \\
(0.022)\end{array}$ \\
\hline Low childhood SES & $\begin{array}{l}0.118^{*} \\
(0.034)\end{array}$ & $\begin{array}{l}0.024 \\
(0.033)\end{array}$ & $\begin{array}{l}0.004 \\
(0.026)\end{array}$ & $\begin{array}{l}0.019 \\
(0.026)\end{array}$ & $\begin{array}{l}0.009 \\
(0.025)\end{array}$ & $\begin{array}{l}0.002 \\
(0.023)\end{array}$ & $\begin{array}{l}-0.010 \\
(0.024)\end{array}$ & $\begin{array}{l}-0.028 \\
(0.025)\end{array}$ & $\begin{array}{l}-0.031 \\
(0.025)\end{array}$ \\
\hline Medium childhood SES & $\begin{array}{l}0.112 * \\
(0.027)\end{array}$ & $\begin{array}{l}0.094 * \\
(0.024)\end{array}$ & $\begin{array}{l}0.053^{*} \\
(0.021)\end{array}$ & $\begin{array}{l}0.041^{*} \\
(0.020)\end{array}$ & $\begin{array}{l}0.020 \\
(0.018)\end{array}$ & $\begin{array}{l}0.021 \\
(0.017)\end{array}$ & $\begin{array}{l}0.011 \\
(0.017)\end{array}$ & $\begin{array}{l}-0.002 \\
(0.017)\end{array}$ & $\begin{array}{l}-0.005 \\
(0.017)\end{array}$ \\
\hline R-squared & 0.103 & 0.121 & 0.122 & 0.135 & 0.150 & 0.178 & 0.208 & 0.218 & 0.218 \\
\hline Observations & 1178 & 1221 & 1234 & 1239 & 1245 & 1246 & 1246 & 1246 & 1246 \\
\hline
\end{tabular}

